$$
\text { UNIVERSIDADE DE SÃO PAULO }
$$

FACULDADE DE FILOSOFIA, LETRAS E CIÊNCIAS HUMANAS DEPARTAMENTO DE LETRAS CLÁSSICAS E VERNÁCULAS PROGRAMA DE PÓS-GRADUAÇÃO EM FILOLOGIA E LÍNGUA PORTUGUESA

Bruna Wysocki

\title{
Interação face a face: um estudo das estratégias discursivas na reconstrução da imagem
}

São Paulo

2007 


\section{BRUNA WYSOCKI}

\section{Interação face a face: um estudo das estratégias discursivas na reconstrução da imagem}

Dissertação apresentada ao Programa de Pós-Graduação em Filologia e Língua Portuguesa, do Departamento de Letras Clássicas e Vernáculas da Faculdade de Filosofia, Letras e Ciências Humanas, da Universidade de São Paulo, para obtenção do título de Mestre em Letras.

Orientadora: Prof ${ }^{\mathrm{a}}$ Dr $^{\mathrm{a}}$ Zilda Gaspar Oliveira de Aquino 


\section{AUTORIZO A REPRODUÇÃO E DIVULGAÇÃO TOTAL OU PARCIAL DESTE TRABALHO, POR QUALQUER MEIO CONVENCIONAL OU ELETRÔNICO, PARA FINS DE ESTUDO E PESQUISA, DESDE QUE CITADA A FONTE.}

Serviço de Biblioteca e Documentação da Faculdade de Filosofia, Letras e Ciências Humanas da Universidade de São Paulo

\begin{tabular}{|l} 
Wysocki, Bruna \\
Interação face a face : um estudo das estratégias discursivas na reconstrução \\
da imagem / Bruna Wysocki ; orientadora Zilda Gaspar Oliveira de Aquino. -- São \\
Paulo, 2007. \\
166 f. \\
Dissertação (Mestrado - Programa de Pós-Graduação em Filologia e Língua \\
Portuguesa. Área de concentração: Filologia e Língua Portuguesa) - Departamento \\
e Letras Clássicas e Vernáculas da Faculdade de Filosofia, Letras e Ciências \\
Humanas da Universidade de São Paulo. \\
1. Melo, Fernando Collor, 1949 -. 2. Sociolingüísitica. 3. Políticos (Entrevista \\
televisiva; Análise do discurso) - Brasil. 4. Estratégia da comunicação. 5. Interação \\
interpessoal. 6. Trabalho da face. 7. Argumentação. I. Título. \\
21a. CDD 417 \\
302.2
\end{tabular}




\section{FOLHA DE APROVAÇÃO}

Bruna Wysocki

Interação face a face: um estudo das estratégias discursivas na reconstrução da imagem

Dissertação apresentada à Faculdade de Filosofia, Letras e Ciências Humanas, da Universidade de São Paulo, para obtenção do título de Mestre em Letras.

Aprovado em:

Banca Examinadora

Prof. Dr. Zilda Gaspar Oliveira de Aquino

Instituição: Universidade de São Paulo

Assinatura

$\operatorname{Prof}^{\mathrm{o}} \operatorname{Dr}^{\mathrm{o}}$ Luiz Antonio da Silva

Instituição: Universidade de São Paulo

Assinatura

Prof ${ }^{0}$ Dr $^{0}$ José Gaston Hilgert

Instituição: Universidade Presbiteriana Mackenzie

Assinatura 


\section{DEDICATÓRIA}

Aos meus avôs, Sebastião de Camargo e Isabel de Souza Camargo, exemplos de vida e de coragem.

À Elisa de Camargo, mãe amorosa, determinada e dedicada à família.

Ao meu marido, Rodrigo de Brito Moreira, exímio companheiro em todos os momentos.

À memória de meu pai, Bruno Wysocki, por tudo o que sou e o que pretendo ser. 


\section{AGRADECIMENTOS}

À Prof ${ }^{a}$ Dr $^{\mathrm{a}}$ Zilda Gaspar Oliveira de Aquino, pelo incentivo e orientação competente, eficiente e segura, além da amizade que fizeram a diferença na minha vida acadêmica e profissional.

Aos professores $\operatorname{Prof}^{\circ} \operatorname{Dr}^{\circ}$ Luiz Antonio da Silva e $\operatorname{Prof}^{\circ}$ Dr $^{\circ}$ José Gaston Hilgert, pelo respeito e atenção dedicados à leitura de meu relatório de qualificação e pelas valiosas observações.

À Prof ${ }^{a}$ Dr $^{\mathrm{a}}$ Lineide do Lago Salvador Mosca, pelas oportunas sugestões durante as aulas da pós-graduação.

Aos amigos e familiares que souberam entender a minha ausência e contribuíram, de alguma maneira, para a realização deste trabalho.

Aos funcionários do Sistema Brasileiro de Televisão (SBT), que gentilmente me enviaram a gravação da entrevista. 
"Cada criatura humana traz consigo duas almas: uma que olha de dentro para fora, outra que olha de fora para dentro..."

(Machado de Assis)

"Fixemo-nos no concreto. O espelho, são muitos, captando-lhe as feições; todos refletem-lhe o rosto, e o senhor crê-se com aspecto próprio e praticamente imudado, do qual the dão imagem fiel. Mas - que espelho? Há-os "bons" e "maus", os que favorecem e os que detraem; e os que são apenas honestos, pois não."

(João Guimarães Rosa) 
WYSOCKI, Bruna. Interação face a face: um estudo das estratégias discursivas na reconstrução da imagem. 2007. Dissertação - Faculdade de Filosofia, Letras e Ciências Humanas da Universidade de São Paulo, São Paulo, 2007.

\section{RESUMO}

O presente trabalho tem por proposta analisar o discurso formulado por um expresidente que pretende reconstruir sua imagem abalada em decorrência do impeachment que sofreu. Ao considerarmos um encontro social, em que os interlocutores interagem face a face, observamos que o interactante procura articular estratégias interacionais, a fim de preservar sua face e protegê-la de eventuais ameaças; ao mesmo tempo, coordena estratégias argumentativas com o intuito de interferir na concepção inicial que seus interlocutores possuem a respeito de sua imagem. Para atingirmos nossos objetivos, consideramos, da Sociolingüística Interacional, as teorias de preservação de faces abordadas por Goffman (1974) e, ao levarmos em conta que estratégias argumentativas também colaboram para a reconstrução da imagem, recorremos aos pressupostos da Teoria da Argumentação, segundo estudos de Perelman e Olbrechts-Tyteca (2002). Com base nesses estudos, partimos para a aplicação dos conceitos em um corpus constituído por uma entrevista televisiva, transmitida pelo Sistema Brasileiro de Televisão (SBT), em agosto de 1998, no "Programa Livre", em que o ex-presidente Fernando Collor de Melo é entrevistado por estudantes de ensino médio e cursinho. O corpus foi gravado e transcrito de acordo com as normas publicadas pelo Projeto da Norma Urbana Culta - NURC-SP.

Palavras-Chaves: estratégias discursivas, imagem pública, preservação das faces, argumentação, reconstrução da imagem 
WYSOCKI, Bruna. Interation face to face: the studie of discourse strategies in reconstruction of the image. 2007. Dissertation (Master's Degree) - Faculdade de Filosofia, Letras e Ciências Humanas da Universidade de São Paulo, São Paulo, 2007.

\begin{abstract}
This paper has the purpose of analyzing the discourse delivered by a former president that plans to rebuild his image, since it was shattered as a result of an impeachment sustained by him. Upon considering a social gathering, in which the interlocutors interact face to face, we have noted that the interacting person tries to coordinate interactional strategies in order to preserve his face and protect it against any threats; at the same time, he organizes strategic arguments for the purpose of interfering with the initial assumption that his interlocutors have made in regard to his image. To achieve our goals, we have used, from the Interactional Sociolinguistics, the theory of faces' preservation as approached by Goffman (1974) and, by taking into account that strategic arguments too cooperate for the reconstruction of the image, we have relied on the assumptions of the Argumentation Theory, according to studies by Perelman \& Olbrechts-Tyteca (2002). With basis on this information, we set out to apply the concepts in a corpus made up by a television interview broadcast by $S B T$, a television network, in August 1998, in the "Programa Livre" talk show, in which former President Fernando Collor de Melo was interviewed by high school students. The corpus was recorded and transcribed according to the rules published by Urban Educated Norm Project - NURC - SP
\end{abstract}

Key words: discourse strategies, public image, face's preservation, argumentation, reconstruction of the image 


\section{SUMÁRIO}

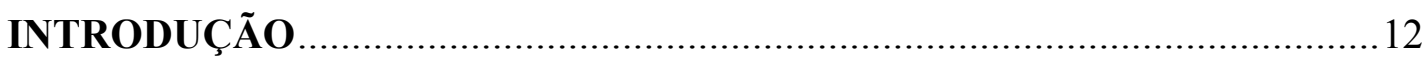

CAPÍTULO I - A entrevista televisiva sob o discurso da mídia.......................20

1.1 Sobre as características que definem o gênero entrevista televisiva..................25

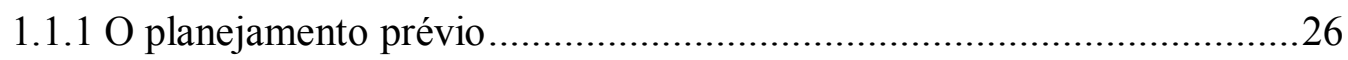

1.1.2 O par pergunta-reposta nas entrevistas televisivas .............................28

1.1.3 A assimetria na interação ................................................................. 30

1.1.4 A preocupação com o público .................................................................33

1.2 A construção de representações sociais na entrevista televisiva ........................36

1.2.1 Características específicas da entrevista televisiva

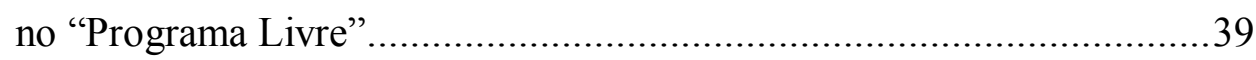

1.2.1.1 Dados da interação no "Programa Livre" ..................................42

CAPÍTULO II - A interação face a face na entrevista televisiva ......................48

2.1 A influência do contexto nas interações face a face ........................................50

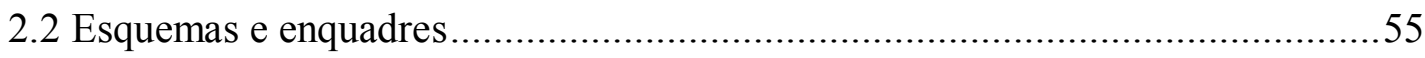

2.3 As mudanças de footing e as pistas de contextualização ................................59

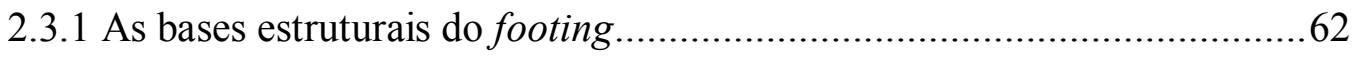

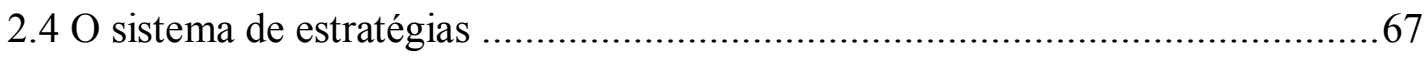

CAPÍTULO III - As estratégias discursivas ............................................. 71

3.1 Estratégias interacionais de preservação da face .............................................73

3.1.1 As práticas de salvamento da face (face-work) ....................................77

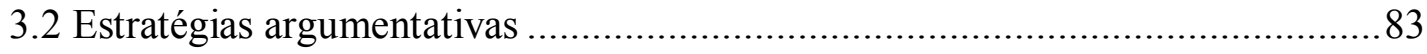

3.2.1. Relações entre o locutor e seus atos .................................................. 88

3.3. A metadiscursividade como recurso textual-interativo ................................90

3.4 A metadiscursividade e a mudança de footing .................................................92 


\section{CAPÍTULO IV - Análise das estratégias utilizadas por}

\section{Fernando Collor de Melo e por seus}

interlocutores durante o "Programa Livre".......................96

4.1 A apresentação de Collor e a imagem atribuída aos entrevistadores..................98

4.1.1 A influência do contexto na reconstrução da imagem..............................98

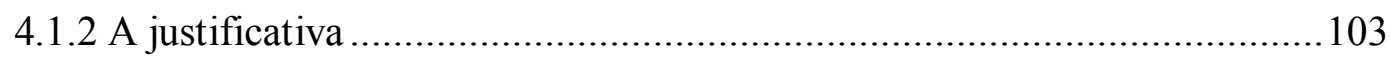

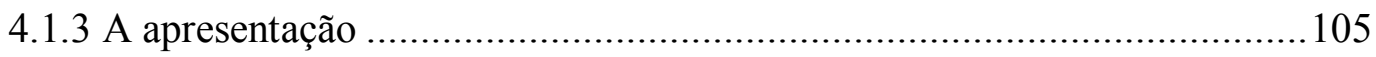

4.1.4 A aproximação ................................................................................ 113

4.2 A imagem de Collor pelos entrevistadores..................................................... 117

$4.3 \mathrm{O}$ mediador no papel de entrevistador........................................................ 128

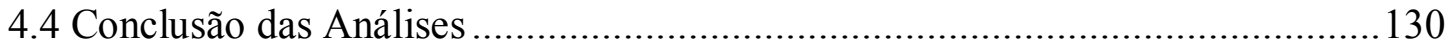

CONCLUSÃO

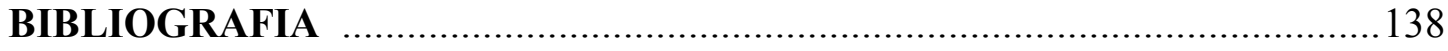

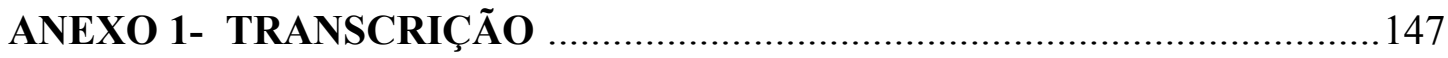

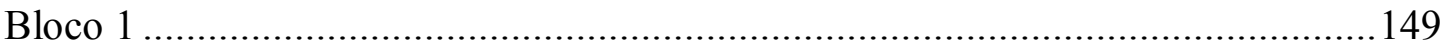

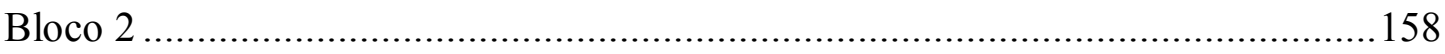

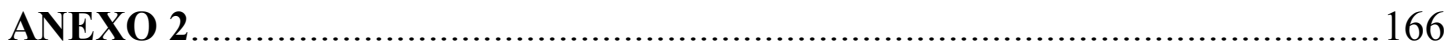




\section{INTRODUÇÃO}


É pertinente aos seres humanos a preocupação em saber se a imagem transmitida aos outros indivíduos, durante um encontro social, é compatível com aquela que realmente desejam transmitir aos que os observam. Seja pela aparência física, seja pelo discurso construído em uma interação verbal, torna-se comum o anseio em garantir uma imagem conforme valores sociais aceitos em determinada cultura.

Num universo marcado por múltiplos contatos sociais é que desempenhamos não um só papel social, mas vários, de acordo com a situação em que nos encontramos (Goffman, 2004). Existe o papel social desempenhado na escola, que é diferente de nosso papel social entre familiares, ou numa igreja, ou no trabalho, ou num clube, enfim, em cada contexto, interagimos com outras pessoas e, durante a atividade interacional, por meio da linguagem verbal, entre outras, transmitimos uma imagem a nosso respeito. Podemos dizer que há uma natural preocupação com a imagem pública ${ }^{1}$, com as informações as quais constituem a impressão que outros interactantes terão a nosso respeito e que determinam nosso papel social em uma situação específica.

No que se refere aos homens públicos, envolvidos com políticas partidárias, sabemos que precisam veicular uma imagem apropriada para conseguirem atingir seus objetivos: entre eles, vencer uma eleição. Neste caso, o trabalho com a construção de uma imagem, compatível com valores e crenças de uma sociedade, torna-se essencial, conforme salienta Goffman (op. cit.).

As pesquisas relacionadas à imagem pública em que se observam as relações sociais entre participantes de uma interação face a face e sua manifestação através do discurso têm sido desenvolvidas na perspectiva teórica da Sociolingüística Interacional;

\footnotetext{
${ }^{1}$ Goffman (1974), em seus estudos, define a noção de face como "image of self delineatead in terms of approved social attributes". Sendo assim, preferimos assumir como "imagem social" ou "imagem pública" a tradução do termo "face" empregada pelo autor.
} 
entretanto, não localizamos estudos direcionados à reconstrução da imagem pública de alguém que tenha passado por alguma sanção social.

Assim, propomo-nos a observar as atividades discursivas de um político, na verdade, um ex-presidente do Brasil que teve sua imagem pública afetada em decorrência de um impeachment e que, às vésperas de um pleito, quis ver alterada essa imagem - trata-se de Fernando Collor de Melo. A pesquisa parece-nos significativa por preencher uma lacuna inexplorada e por permitir conhecer um pouco mais sobre a interação humana. Ainda mais, selecionamos uma situação de entrevista peculiar a ser analisada: o ex-presidente é entrevistado durante um programa de auditório transmitido por uma emissora de TV do qual participam estudantes universitários. Os jovens são os entrevistadores e formulam perguntas ao entrevistado, mediados por Sérgio Groisman, durante o Programa Livre, transmitido pelo Sistema Brasileiro de Televisão - SBT. Os estudantes que participam do programa não são entrevistadores profissionais e não constituem um público especializado nos diversos assuntos abordados durante a entrevista com o ex-presidente. $^{2}$

Com o intuito de entendermos o modo como o entrevistado constrói seu discurso para reconquistar sua imagem, consideramos algumas questões referentes àqueles que possuem envolvimento com a entrevista (entrevistado, mediador, entrevistadores, telespectador):

1- Quem são esses envolvidos?

2- Como elaboram seus discursos?

3- Qual o papel social desempenhado por eles?

4- Qual a possível imagem que eles possuem uns dos outros?

\footnotetext{
${ }^{2}$ Numa participação do auditório do "Programa Livre", pude constatar que, no programa transmitido ao vivo, os jovens anotam suas perguntas durante a entrevista e escolhem aquele que os representarão falando ao microfone. Essa ação, entre os jovens, pode ser observada no corpus gravado, quando alguns deles lêem as perguntas anotadas em papéis.
} 
5- Como suas crenças, valores e opiniões interferem no próprio discurso e no discurso alheio?

6- Qual a imagem que o próprio entrevistado tem de si mesmo?

O conhecimento do contexto de produção do discurso do entrevistado e as relações sociais estabelecidas entre os participantes da entrevista contribuirão para apontarmos e entendermos, no discurso de reconstrução da imagem, o funcionamento das estratégias discursivas utilizadas pelos interlocutores.

Constatamos que essas questões enumeradas proporcionarão um reconhecimento dos entrevistadores, mediador, telespectador e das condições de produção para podermos analisar e compreender o discurso de reconstrução da imagem do entrevistado, principal objetivo de nosso trabalho. Essas questões irão também nos ajudar a definir os procedimentos a serem trilhados, para não somente apontarmos as estratégias discursivas utilizadas na tentativa de reconstrução de uma imagem pública, tão desgastada por escândalos políticos, mas, principalmente, para nos auxiliar a buscarmos entender como essas estratégias funcionam durante uma interação verbal, em que valores diferentes ajudam a promover uma situação de conflito.

Sabemos que o discurso é rico quanto à possibilidade de análise de inúmeras estratégias, mas preferimos destacar duas delas: as estratégias interacionais e as estratégias argumentativas. As estratégias interacionais foram selecionadas por estarem diretamente relacionadas à manutenção e preservação da imagem social de um interactante. Para analisá-las, recorremos aos pressupostos teóricos da Sociolingüística Interacional relacionados às mudanças de footing, estrutura de participação, formato de produção, encaixamento, enquadre, esquema e face-work. 
As estratégias argumentativas, por sua vez, foram analisadas devido ao caráter argumentativo da linguagem produzida em interações verbais. Assim, ao admitirmos o caráter social da língua precisamos reconhecer que a linguagem é uma maneira de agir sobre o outro, ou seja, que ela se manifesta através de enunciados que procuram provocar no interlocutor uma determinada reação de acordo com os objetivos do locutor. Nesse sentido, Halliday (1994:94) afirma que todo discurso é retórico "na medida em que tenta prevalecer uma determinada visão da realidade - (...) o do ator político, apresentando razões para o que fez, faz e fará”.

O que se apresenta permite dizer que, juntamente com estratégias interacionais, localizamos estratégias argumentativas as quais também contribuem para a mudança de opinião de um interlocutor a respeito da imagem pública de um locutor. Sendo assim, recorremos, também, aos pressupostos teóricos da Teoria da Argumentação, baseada nos estudos de Perelman e Olbrechts-Tyteca (2002) sobre as "técnicas argumentativas", para explicarmos como se organizam as estratégias argumentativas no discurso de um político que pretende mudar sua imagem social.

Para que se proceda à análise da reconstrução de uma imagem pública, impõe-se a necessidade da escolha de um material que disponha indivíduos em interação face a face, num encontro social. Considerando-se essa condição, a entrevista concedida por Collor parece-nos um valioso material, visto que, além de ocorrer em interação face a face, observa-se um encontro social específico, pois, a imagem do ex-presidente, associada a valores culturais e sociais negativos, pode tornar a tarefa de reconstrução da imagem muito delicada.

A entrevista televisiva que constitui o corpus selecionado para a análise foi transmitida pelo SBT (Sistema Brasileiro de Televisão), em agosto de 1998, no "Programa Livre", em que o ex-presidente Fernando Collor de Melo é entrevistado por 
estudantes de ensino médio, cursinhos e faculdades. A entrevista tem como mediador Sérgio Groisman, que também elabora algumas perguntas ao entrevistado. O programa, apresentado em sessenta minutos, foi dividido em dois blocos, os quais estão totalmente transcritos na parte destinada aos Anexos deste trabalho (página 147).

O contato com entrevistadores não especializados, pertencentes a uma faixa etária classificada como adolescência, e o fato de o programa ter sido transmitido ao vivo $^{3}$ constituíram características específicas da entrevista e influenciaram na escolha do material para a pesquisa.

O material gravado foi transcrito de acordo com as normas publicadas pelo Projeto da Norma Urbana Culta, núcleo-SP (NURC-SP, 1999: 11), reproduzidas pela tabela I, a seguir. Os dados obtidos serão analisados conforme o aparato teórico da Sociolingüística Interacional e da Teoria da Argumentação, como já indicamos, envolvendo estudos sobre a interação, contexto, imagem pública e estratégias discursivas.

Tabela I - Normas para transcrição

\begin{tabular}{|l|c|}
\hline \multicolumn{1}{|c|}{ Ocorrências } & Sinais \\
\hline \hline $\begin{array}{l}\text { Incompreensão de palavras ou } \\
\text { segmentos }\end{array}$ & ( ) \\
\hline Hipótese do que se ouviu & (hipótese) \\
\hline $\begin{array}{l}\text { Truncamento (havendo homografia, } \\
\text { usa-se acento indicativo da tônica e/ou } \\
\text { timbre) }\end{array}$ & $/$ \\
\hline Entoação enfática & maiúscula \\
\hline
\end{tabular}

\footnotetext{
${ }^{3}$ Apesar de muitos teóricos não acreditarem nas entrevistas sem preparo prévio, transmitidas ao vivo pela televisão, um dos motivos da escolha desse material ocorreu devido a minha participação, como parte do auditório e entrevistadora, em outras entrevistas do Programa Livre, em que pude constatar e vivenciar a improvisação das perguntas elaboradas pelos jovens.
} 


\begin{tabular}{|l|c|}
\hline $\begin{array}{l}\text { Prolongamento de vogal e consoante } \\
\text { (como s, r) }\end{array}$ & $\begin{array}{c}\text { :: podendo aumentar para :.:: ou } \\
\text { mais }\end{array}$ \\
\hline Silabação & - \\
\hline \hline Interrogação & ? \\
\hline Qualquer pausa & $($ minúsculas $))$ \\
\hline Comentários descritivos do transcritor & -- -- \\
\hline $\begin{array}{l}\text { Comentários que quebram a seqüência } \\
\text { temática da exposição; desvio temático }\end{array}$ & $\{$ ligando as linhas \\
\hline Superposição, simultaneidade de vozes & $(\ldots)$ \\
\hline $\begin{array}{l}\text { Indicação de que a fala foi tomada ou } \\
\text { interrompida em determinado ponto. } \\
\text { Não no seu início, por exemplo. }\end{array}$ & $"$ " \\
\hline $\begin{array}{l}\text { Citações literais ou leituras de textos, } \\
\text { durante a gravação }\end{array}$ & \\
\hline
\end{tabular}

Embora possamos observar o texto em sua unidade significativa, metodologicamente foi decisivo observar o discurso do mediador, dos jovens e de Collor. Ao analisar o discurso do ex-presidente, detivemo-nos em sua organização discursiva, tendo em vista a reconstrução de sua imagem, não só para seu interlocutor direto (Groisman e estudantes), mas, também, de seu interlocutor "indireto" que se constitui do público telespectador.

A partir do que se apresenta, esta dissertação estrutura-se em quatro capítulos, além da introdução, conclusão, bibliografia e anexos:

Capítulo I - A entrevista televisiva sob o discurso da mídia - realizamos algumas considerações a respeito da noção de gênero e, ao levantarmos características que definem o gênero entrevista televisiva, apontamos sua influência sobre a (re) construção de imagens sociais. 
Capítulo II - A interação face a face na entrevista televisiva - salientamos a importância do reconhecimento de dados contextuais para a compreensão durante uma interação verbal. Desta forma, abordamos questões relacionadas ao contexto de situação e ao contexto cognitivo, em que conceitos, como esquemas, enquadres, footing e pistas de contextualização são estudados a fim de ajudar-nos a entender como os interactantes compreendem, organizam e utilizam estratégias discursivas de acordo com seus objetivos.

Capítulo III - As estratégias discursivas - apresentamos as estratégias interacionais que procuram garantir o bom desempenho de um evento e as estratégias argumentativas que pretendem influenciar o sistema de conhecimento de mundo na tentativa de mudar a opinião do interlocutor. Juntas, essas estratégias discursivas podem ser utilizadas para mudar a concepção de um público a respeito da imagem de um locutor.

Capítulo IV - Análise das estratégias utilizadas por Collor e por alguns interlocutores durante o "Programa Livre" - são retomados os conceitos abordados nos capítulos anteriores para analisar as estratégias interacionais de preservação da face que contribuem para a tentativa de reconstrução da imagem e as estratégias argumentativas que auxiliam nesse processo de reconquista da imagem pública. 


\section{CAPÍtULO I}

A ENTREVISTA TELEVISIVA SOB O DISCURSO DA MÍDIA 
Há muito tempo os gêneros têm sido abordados sob a ótica de diversas vertentes, sendo estudados pela Retórica Antiga, pela Análise Literária em seus múltiplos critérios de classificação e, mais atualmente, pelos estudos da Lingüística a respeito de textos não literários. As diferentes classificações propostas por essas correntes refletem a organização cultural e o modo de produção dos meios de comunicação em determinado momento da história de uma sociedade específica.

Os diversos estudos sobre o gênero revelam uma preocupação do homem em explicitar os modos encontrados para se comunicarem. De acordo com Bakhtin (2003:263):

(...) cada campo de utilização da língua elabora seus tipos relativamente estáveis de enunciados, os quais denominamos gêneros do discurso.

A riqueza e a diversidade dos gêneros discursivos são ilimitadas, porque as possibilidades de atividade humana são também inesgotáveis e porque cada esfera de atividade contém um repertório inteiro de gêneros discursivos que se diferenciam e se ampliam na mesma proporção que cada esfera particular se desenvolve e se torna cada vez mais complexa.

Assim, novos gêneros aparecem de acordo com novas necessidades sociais e culturais e, nos últimos séculos, principalmente em relação aos avanços tecnológicos: a imprensa escrita, o rádio, a televisão, a internet são suportes da mídia que impulsionaram a criação de novos gêneros, tanto na oralidade quanto na escrita.

Para Marcuschi (2002:19), os gêneros:

surgem emparelhados a necessidades e atividades sócio-culturais, bem como na relação com inovações tecnológicas, o que é facilmente perceptível ao se considerar a quantidade de gêneros textuais hoje existente em relação a sociedades anteriores à comunicação escrita.

A esse respeito Machado (1999) destaca a heterogeneidade e a mutabilidade dos 
gêneros não só porque são diferentes entre si, mas também porque existe a possibilidade de um enunciado envolver muitos gêneros ao mesmo tempo. Desta maneira, o autor considera que os gêneros podem resultar de dois ou mais gêneros.

Os gêneros se ancoram em outros já existentes e se misturam na constituição de novos gêneros segundo as transformações culturais e tecnológicas de um povo. Com isso, gêneros como editoriais, artigos, notícias, telefonemas, teleconferências, reportagens, e-mails, blogs, aulas virtuais, entrevistas e debates coincidem com novos suportes de comunicação, os quais poderão até mesmo servir como critério para certas classificações atuais de gêneros.

Para Fechine (2001:16), em todos os gêneros há "sempre constituintes genéricos que permanecem e há sempre elementos específicos que mudam de acordo com as transformações socioculturais, entre as quais se inclui o próprio surgimento de novas mídias". Assim, é possível afirmar que os gêneros organizam a linguagem dentro de uma mídia específica e diferentes mídias podem colaborar para o aparecimento de diferentes gêneros.

Segundo concepção de Charaudeau (2006), a mídia é um suporte organizacional que abrange as noções de comunicação e informação, para integrá-las em diversas lógicas econômica, tecnológica e simbólica.

A lógica econômica aproxima o tratamento da informação ao funcionamento de uma empresa, cujo objetivo é "fabricar um produto que se define pelo lugar que ocupa no mercado de troca de bens de consumo." (op. cit: 21). A lógica tecnológica relaciona-se com a qualidade e quantidade da difusão atingida pela mídia. A lógica simbólica, por sua vez, é aquela que detém o maior destaque entre os estudiosos, devido sua finalidade de fazer com que todo organismo de informação participe da construção da opinião pública; é a lógica pela qual observamos "como os indivíduos regulam as trocas sociais, constroem as representações dos valores que subjazem a suas práticas, criando e manipulando signos e, por conseguinte, 
produzindo sentido" (op. cit: 16).

Ao abordar características da mídia para tentar analisar o discurso de informação, Charaudeau (2006) propõe uma classificação dos gêneros segundo o suporte midiático: jornalísticos (imprensa escrita), televisivos e radiofônicos. Para o autor (op. cit.), os gêneros de informação midiática são definidos conforme o cruzamento entre tipo de instância enunciativa, modo discursivo, conteúdo temático e dispositivo.

A instância enunciativa envolve todos aqueles comprometidos com a construção de um certo saber, ou seja, com a transmissão da notícia via mídia. É constituída pela instância de produção (os responsáveis pela informação), que corresponde à origem do sujeito falante e seu grau de implicação: pode ser um jornalista (sua origem está na própria mídia) ou um convidado, político, especialista, testemunha (origem externa à mídia); e pela instância de recepção (a que público a informação é direcionada), determinada de acordo com o suporte midiático: na imprensa, são os leitores; no rádio, os ouvintes e na televisão, os telespectadores.

Existe uma relação muito complexa entre a instâncias de produção e de recepção, pois a informação é transmitida de acordo com as representações que se constroem a respeito do público e nem sempre essas representações constituem a realidade. A instância de produção não tem contato direto com o público, não pode saber de imediato as reações de quem recebe as informações e não pode dialogar, retificando a apresentação da informação; o que existe são pesquisas que tentam definir o perfil de leitores, ouvintes e telespectadores, mas acabam constituindo apenas hipóteses e previsões sobre determinado público.

O modo discursivo corresponde às propriedades que transformam o acontecimento em notícia: relatos ou declarações de fatos e ações que constituem o acontecimento ocorrido no espaço público (acontecimento relatado); comentários e análises do porquê e como ocorreu o 
acontecimento, sob o ponto de vista de especialistas que tentam justificar seus posicionamentos (acontecimento comentado); provocação do confronto de idéias com o auxílio de diferentes dispositivos, como a entrevista e o debate (acontecimento provocado).

O acontecimento provocado será caracterizado por apresentar: indivíduos exteriores à mídia (que não são jornalistas), cuja presença é justificada pela identidade social (especialista, analistas, testemunhas) e motivados pela escolha de um tema atual, e um representante das mídias (entrevistador ou mediador), num espaço de visibilidade adequado (páginas de opiniões da imprensa escrita, entrevistas, bate-papos ou debates).

O conteúdo temático é composto pelo macrodomínio abordado pela notícia (acontecimento político, esportivo, cultural,...). A combinação entre o modo discursivo e o tema auxilia na distinção dos subgêneros ${ }^{1}$ - os debates (acontecimento provocado), por exemplo, podem ser determinados de acordo com diferentes temas relacionados ao universo cultural, científico ou de sociedade.

O tipo de dispositivo possibilita diferenciar o gênero de acordo com o suporte midiático - imprensa, rádio e televisão. É o que nos possibilita distinguir uma entrevista radiofônica de uma entrevista televisiva. Os mesmos gêneros podem sofrer algumas alterações quando apresentados em suportes midiáticos diferentes. O rádio, por exemplo, enfatiza nas entrevistas as sutilezas da voz que se revelam à audição, como sentimentos favoráveis ou desfavoráveis, a afetividade, as emoções, a sinceridade ou a mentira; já nas entrevistas televisivas, os gestos, os olhares e expressões faciais são mais explorados dentro desse gênero.

Com o passar do tempo, os gêneros podem sofrer alterações conforme as evoluções tecnológicas do suporte midiático e com a moda prevalente em relação à maneira de contar,

\footnotetext{
${ }^{1}$ Charaudeau (2006), em seus estudos sobre o gênero de informação midiática, propõe a distinção de subgêneros a partir do tema. Assim, ao relacionar o gênero debate a temas como cultura e ciência, encontraríamos os subgêneros debate cultural e debate científico.
} 
entrevistar, debater. Sendo assim, localizamos, de fato, em alguns programas, procedimentos que constituem características específicas de um determinado gênero, influenciadas pelo dispositivo midiático, pela instância de enunciação, pelo conteúdo temático e pelo modo discursivo escolhido para transmitir a informação, ou seja, os gêneros constituem uma relação social de reconhecimento, própria a seu contexto sociocultural, e podem variar de um contexto a outro e de uma época a outra (Charaudeau, 2006).

Nesse sentido, faz-se necessária uma abordagem das principais características que definem o gênero entrevista televisiva para, posteriormente, procedermos a observações do gênero no programa televisivo a ser analisado. Destacamos a importância de reconhecermos as especificidades do contexto sociocultural e do momento histórico em que foi produzido tal gênero e disto trataremos a seguir.

1.1 Sobre as características que definem o gênero entrevista televisiva

A entrevista caracteriza-se pelo contato social entre dois ou mais interlocutores que iniciam uma troca verbal ou conversação, num lugar determinado, onde um jogo de perguntas e respostas é realizado, a fim de que possam trocar informações pertinentes a um determinado grupo social. Sua finalidade é o inter-relacionamento humano, em que seus participantes "interagem, se modificam, se revelam, crescem no conhecimento do mundo e deles próprios" (Medina, 1986:9).

Andrade (2000:73), ao abordar as entrevistas de TV no discurso da mídia, propõe a seguinte definição: 
em suas várias aplicações, a entrevista é uma técnica de interação social. Por meio dela, busca-se uma interpenetração informativa que visa a quebrar isolamentos sociais, pode ainda servir à pluralização de vozes e à distribuição democrática da informação, constituindo sempre um meio cujo objetivo fundamental é o inter-relacionamento humano.

Delimitada segundo seu suporte midiático, a entrevista possui características específicas, de acordo com o contexto em que é desenvolvida. Assim, quando é organizada para ser transmitida na televisão, terá como objetivo informar um telespectador (público) sobre determinado assunto de seu interesse, não só através de trocas verbais, mas também por meio de imagens selecionadas pela equipe do programa televisivo.

A entrevista se diferencia de outras situações conversacionais, na medida em que possui características próprias, como o planejamento prévio dos tópicos a serem desenvolvidos durante o evento, o par pergunta-resposta, a assimetria na interação e a preocupação com o público.

Isso nos permite dizer que a entrevista televisiva pode ser considerada um tipo particular de conversação, na medida em que um diálogo é construído entre interlocutores; porém, trata-se de um diálogo que se distancia das características de uma conversação espontânea e que se define por convenções específicas, conforme indicamos a seguir.

\subsubsection{O planejamento prévio}

Numa conversação espontânea, podemos observar a possibilidade de planejamento ou replanejamento no mesmo instante em que os interlocutores produzem seus enunciados. Entretanto, encontramos um planejamento prévio da conversação nas entrevistas televisivas, 
tanto por parte do entrevistado, em alguns casos, quanto por parte do entrevistador, que precisa planejar os tópicos a serem abordados, as perguntas, o direcionamento da conversação (quando interromper ou terminar), a distribuição dos turnos e até mesmo estabelecer um caráter contratual ou polêmico à entrevista, se for o caso.

Assim, a entrevista conta com três momentos definidos: a preparação da pauta, a entrevista propriamente dita e a edição. Durante a entrevista, os interlocutores colocam em prática, oralmente, o que foi planejado, mas isso não garante que tudo ocorra como planejado, pois estratégias discursivas serão escolhidas simultaneamente à conversação e nem sempre essas escolhas correspondem às expectativas dos interlocutores que se prepararam para o encontro social.

O responsável pela edição é, normalmente, um outro interlocutor que, ao selecionar trechos da entrevista, colabora com o produto final, conforme os objetivos da mídia, podendo até mesmo provocar mudanças no sentido do texto construído pelo entrevistador e entrevistado no momento da entrevista. Já no caso das entrevistas ao vivo, a falta de uma edição final é compensada por um maior planejamento conversacional (Barros, 1991: 259), pois qualquer tentativa de controlar os acontecimentos ocorridos, durante uma determinada entrevista televisiva, deve ser feita no ato de sua realização.

Conforme a autora (op. cit,) a manipulação ocorre quando o grupo que mantém a mídia (jornal, rádio, televisão) e os telespectadores determinam, no planejamento, os valores em jogo na entrevista e a direção que ela deve tomar. Sendo assim, depois de realizada a entrevista, ou seja, o momento em que os interlocutores agem de acordo com suas características próprias, encontramos, na edição, sanções realizadas pelo editor que, ao pressupor os anseios do público-alvo, julga a ação dos interlocutores e atribui-lhe sentido.

O tempo existente entre o momento da gravação de uma cena e a exibição do produto 
final é considerado por Machado (2001) um intervalo de elaboração que corresponde ao tempo da manipulação. Contudo, nas transmissões ao vivo, perde-se a possibilidade de contar com o tempo da manipulação. Assim, nestes casos, o planejamento prévio torna-se essencial para a boa condução da entrevista pelo entrevistador, visto que ele não poderá contar com os recortes de uma edição, onde seria possível alterar situações provavelmente não desejadas pela equipe de produção.

De acordo com Brito (1997:37), “ainda que o entrevistador possa ficar, algumas vezes, dependente do roteiro, com o intuito de melhor encaminhar a entrevista, o texto produzido principalmente pelo entrevistado evidencia as características básicas do texto conversacional”. Dessa forma, os participantes de uma entrevista - onde o acontecimento é provocado - ainda conservam, na produção dos enunciados, várias características da língua falada, próprias de uma conversação espontânea, como repetições, hesitações, correções, paráfrases e outras marcas do texto oral.

\subsubsection{O par pergunta-reposta nas entrevistas televisivas}

Perguntas e respostas podem estar presentes em qualquer conversação, de acordo com os objetivos da interação e com o contexto em que se encontram os interactantes. Nas entrevistas televisivas, elas adquirem um grande destaque, porque muitas vezes são utilizadas, estrategicamente, na representação de papéis sociais ou até mesmo na manipulação das informações fornecidas ao telespectador.

As perguntas podem ser usadas para obter determinadas respostas, direcionar a entrevista, ajustar a participação dos interlocutores e / ou reorganizar o contexto. Através das 
perguntas, o entrevistador cria determinadas situações que interferem na condução das entrevistas: algumas questões podem ser um tanto embaraçosas para o entrevistado responder e com isso duas conseqüências tornam-se possíveis: ou o entrevistado se irrita e demonstra indignação, ou conta o que sabe para conseguir se livrar da situação constrangedora ocasionada pela pergunta (Aquino, 1997).

As perguntas também podem constituir uma emboscada, quando o entrevistador já conhece a resposta, mas quer, estrategicamente, a partir dela, introduzir um argumento mais forte ou até mesmo um contra-argumento.

O entrevistador hábil é aquele que consegue captar as indagações do público e provocar uma interação em que obtenha as informações necessárias e condizentes com as expectativas do público. Assim, ele precisará ser alguém bem informado, possuir um roteiro ou um pré-questionário e saber enriquecê-los com novas questões no momento da entrevista.

O entrevistado contribui com a entrevista ao fornecer respostas objetivas, de modo que não ignore ou fuja às perguntas elaboradas. O sucesso da entrevista depende do interrelacionamento entre entrevistador e entrevistado que precisam construir, juntos, um texto pertinente às expectativas do telespectador.

Contudo, é preciso observar também que, nem sempre, na interação verbal, uma pergunta é seguida por uma resposta. Dependendo da negociação entre os participantes da interação, do conhecimento partilhado e do contexto em que se encontram, essa ordem pode ser alterada, pois não há uma lógica que determine a organização do par (Fávero et. al., 1996). É o caso do entrevistador que faz uma pergunta e pode ser surpreendido por outra pergunta de seu entrevistado, ou o entrevistador que realiza uma pergunta e complementa com outra a seguir.

Fávero et al. (1996) verificam que perguntas e respostas constituem estratégias 
utilizadas pelos interactantes durante uma interação verbal e podem ser utilizadas para introduzir, continuar, redirecionar ou mudar um tópico. Ao analisarem a forma das perguntas, as autoras (op. cit.) abordam dois grandes tipos: perguntas fechadas (ou de sim / não) e perguntas abertas (ou sobre algo). Quanto à natureza das perguntas, constatam que estas podem oferecer pistas a respeito dos prováveis tipos de perguntas, registrados como:

a- pedido de informação - a resposta pode se apresentar com acordo, dúvida, negação, implicatura ou fornecimento;

b- pedido de confirmação - a resposta pode ocorrer como confirmação positiva ou confirmação negativa;

c- pedido de esclarecimento em relação à audição do enunciado ou pedido de esclarecimento em relação ao conteúdo enunciado - a resposta pode preencher esse pedido como foi solicitado ou, no caso do interlocutor não entender o que foi proferido, este pode solicitar que a pergunta seja repetida.

d- Pergunta- retórica: o locutor elabora a pergunta a fim de que o interlocutor não a responda e, desta maneira, mantém o turno e estabelece contato (função fática).

Como pudemos perceber, as perguntas e respostas, na entrevista televisiva, não constituem somente estratégias para obter informações, pois, durante a interação verbal, são elaboradas de acordo com vários outros objetivos intencionados pelos interactantes.

\subsubsection{A assimetria na interação}

Para Marcuschi (2003:16), ao contrário do diálogo simétrico encontrado nas conversas diárias e naturais, a entrevista constitui um exemplo de diálogo assimétrico, "em que um dos 
participantes tem o direito de iniciar, orientar, redigir, concluir a interação e exercer pressão sobre o (s) outro (s) participante (s)".

Isto nos leva a observar que, nas entrevistas, os interlocutores possuem um papel discursivo correspondente a um conjunto de deveres e direitos comunicativos, ou seja, a um saber agir de acordo com o contexto específico de interação colocado em prática pelos interactantes; e um papel social, determinado pelas ações e representações que determinam uma identidade social dentro de uma comunidade (Andrade, 2000).

Esses distintos papéis discursivos e sociais desempenhados pelos interlocutores são os responsáveis pelo caráter assimétrico das entrevistas, isto é, a assimetria é determinada pela heterogeneidade da posição dos interlocutores. É assim que encontramos, nas entrevistas, interactantes que detêm por mais tempo o turno de fala porque o papel discursivo entrevistado - exige que forneçam mais informações sobre determinado tópico. Em entrevistas com mais de um entrevistado, a assimetria pode ser ocasionada em função de papéis sociais desiguais e suas relações com o tópico desenvolvido: um médico poderá deter o turno, por mais tempo, quando estiver discutindo o tópico saúde com um economista, por exemplo.

Pelo exposto, podemos constatar que a entrevista não constitui um diálogo ocasional, em que ocorrem trocas informais de opiniões e informações; nela, encontramos entrevistador e entrevistado que possuem papéis discursivos bem definidos e orientados: de um lado, o entrevistador que possui poder e dever de questionar, conduzir, propor, sugerir, selecionar e terminar os tópicos, decidir quando ceder o turno ou interrompê-lo; do outro, um entrevistado que detém informações, queixas, saberes, pedidos. Sendo assim, garante-se "um certo equilíbrio na conversação: a um cabe a seleção do tópico e a direção da conversação, ao outro, a manutenção da vez" (Barros, 1991).

A interação é um processo dinâmico em que observamos uma relação de poder entre 
os interactantes, capaz de ser modificada de acordo com as exigências de determinada interação construída a partir das especificações de um gênero. Conforme corrobora KerbratOrecchioni (2006:75), nas entrevistas:

o entrevistador exerce sua autoridade sobre a estruturação da interação (que ele "conduz", tomando a maioria das "iniciativas"), mas, por outro lado, abdica de um outro privilégio, já que seu papel é menos o de falar que o de suscitar a fala do outro, a quem delega a tarefa de fornecer o essencial da matéria conversacional, e a quem coloca em evidência.

Nesse sentido, podemos dizer que essa relação de poder não é estanque, pois, em contextos específicos encontrados nos diferentes momentos históricos e de acordo com a importância do papel social dos interlocutores, é possível alternarem-se os papéis discursivos.

Desta maneira, existem entrevistas em que nos deparamos com uma inversão de papéis discursivos ocasionados pela importância social do entrevistado, que seleciona os tópicos e decide quando passar o turno. Em outros casos, podemos encontrar entrevistadores peculiares os quais dominam toda a entrevista, não cedendo, ao entrevistado, os turnos que lhes são devidos (Fávero, 2000).

O reconhecimento dos papéis discursivos desempenhados pelos participantes de uma entrevista é determinado por um acordo prévio. Isto significa que um contrato das condições de realização da conversação é estabelecido pelos interlocutores, em que reconhecem os papéis sociais e discursivos dos participantes da entrevista, a finalidade e o discurso dominante do encontro social, o suporte midiático e as escolhas discursivas dos interlocutores durante a interação.

Sobre os acordos estabelecidos entre os interactantes, Koch (2005:37) afirma que: 
toda interação envolve a negociação de uma definição da própria situação e das normas que a governam. Na verdade, todos os aspectos da situação relativos aos participantes estão sujeitos à negociação. Isso vai resultar numa construção social da realidade, já que, sendo a realidade social e constituída no processo contínuo de interpretação e interação, os seus vários aspectos podem ser considerados e (re)negociados de forma explícita ou implícita.

Entretanto, precisamos atentar para o fato de que o contrato de comunicação não determina tudo, visto que, durante uma interação verbal, estratégias lingüísticas individuais podem ser utilizadas pelos interlocutores.

Assim sendo, Charaudeau (2006) denomina "projeto de fala" a possibilidade do interlocutor escolher os modos de expressão que correspondam a seu próprio projeto de fala, ao realizar um ato de linguagem. Para o autor, contrato de comunicação - com suas restrições situacionais e discursivas - e projeto de fala - com suas estratégias - se completam e fazem do ato de linguagem um ato de liberdade, porém uma liberdade vigiada.

Nessa perspectiva, o contrato de comunicação apresenta certa maleabilidade, visto que os papéis discursivos exercidos pelos interlocutores podem sofrer alterações, subvertendo, deste modo, a ordem pré-estabelecida da entrevista. Isto demonstra, também, que o poder atribuído ao entrevistador não é tão rígido a ponto de não poder ser modificado durante interação em curso.

1.1.4 A preocupação com o público

As entrevistas televisivas diferenciam-se das conversas espontâneas, porque 
minimizam relações de caráter mais intimista, entre eu e tu, no aqui e agora, típicas das conversações, para privilegiarem uma relação entre o eu e o público (Barros, 1991). Diante disto, rompem com um dialogismo restrito, pois, quando interagem entrevistador e entrevistado, preocupam-se com o falar na sociedade, a fim de conquistar um público (telespectador) e estabelecer uma relação interacional unilateral.

Entrevistador e entrevistado, conforme já salientamos, possuem papéis discursivos bem definidos, porém, eles constroem seus discursos com o objetivo de informar e construir uma imagem determinada a um terceiro interlocutor que está ausente, fisicamente, do encontro face a face, mas participa, indiretamente ${ }^{2}$, da interação: o público.

Conforme indicação de Brito (1997:24), na entrevista realizada na TV, estabelecem-se quatro tipos de interação:
a) entrevistador $X$ entrevistado
b) entrevistado $\mathrm{X}$ público
c) entrevistador X público
d) entrevistador + entrevistado X público

A entrevista é um encontro social em que os interlocutores não só se preocupam com a conversação estabelecida entre entrevistador e entrevistado, como também com a interação estabelecida com seu público. Essa interação, embora indireta, é que determina a direção dada à entrevista. Não são raras as situações em que a porcentagem de telespectadores que assistem

\footnotetext{
${ }^{2}$ Fávero e Aquino (2003:169), ao estudarem questões referentes ao debate televisivo trilogal, destacam que o público é indireto aparentemente, pois ele é a razão do debate, sendo, portanto, o elemento principal. No caso da entrevista televisiva, também podemos admitirmos que o público constitui a razão da entrevista e, assim, assumimos sua participação aparentemente indireta.
} 
à TV é determinante para que se definam algumas características de determinada entrevista.

Entrevistador e entrevistado assumem seus papéis discursivos na interação face a face, ao mesmo tempo em que constroem seus enunciados, a partir do que consideram aceitável para a compreensão e apoio do público, ou seja, eles pressupõem as reações desse público e organizam seus discursos a fim de ganharem a simpatia dele.

A relação interacional e os procedimentos lingüísticos são determinados por um jogo duplo de comunicação: a interação entre entrevistador e entrevistado e a interação de ambos com o público. Porém, são interações diferentes, pois a primeira dá-se face a face, em que é possível completar, retificar e argumentar o que foi enunciado pelo interlocutor; a outra, não possibilita ao público interagir diretamente na conversação estabelecida, pois não há trocas de turnos.

Sendo assim, enquanto a relação entre entrevistador e entrevistado pode sofrer alterações, conforme já exposto neste capítulo, a relação entre entrevistador ou entrevistado e público não são passíveis de inversão, visto que esse tipo de interação não é realizada face a face.

É significativo lembrar que alguns programas contam com um sistema de cartas, emails e telefonemas para a participação dos telespectadores, porém, apesar da contribuição na elaboração de perguntas, as possibilidades de interagirem na manutenção de um tópico ou na troca de turnos continuam reduzidas nos programas de entrevistas televisivas.

Enquanto o entrevistador é aquele que pretende fazer seu interlocutor informar, explicar, justificar; o entrevistado procura atender às expectativas de seu entrevistador; porém, ambos procuram informar e convencer o público. Isso nos permite identificar um caráter particular na interação entre entrevistado e entrevistador: são, ao mesmo tempo, cúmplices na tarefa de comunicação comum e oponentes na conquista desse público (Barros, 1991). 
Desta maneira, as entrevistas (op. cit) estão próximas a um pólo do contrato ou a um pólo da polêmica. No primeiro, os participantes da entrevista buscam causar boa impressão para o público, cedendo o turno, respeitando a fala do outro e evitando demonstrar traços de agressividade. No segundo pólo, pode ocorrer a desqualificação do entrevistador ou do entrevistado.

Seja uma entrevista contratual ou polêmica, entrevistador e entrevistado estão preocupados em interagir com o público, de modo a persuadí-lo e manter, construir ou reconstruir uma imagem pública adequada com seus objetivos durante a entrevista, conforme veremos no próximo item.

1.2 A construção de representações sociais na entrevista televisiva

Os participantes de uma interação verbal precisam elaborar seus enunciados de acordo com seus propósitos e, principalmente, com a categoria e papéis sociais desempenhados pelos interlocutores. Assim, numa entrevista televisiva, os interlocutores face a face preocupam-se em garantir uma imagem adequada de si mesmos considerando as características do gênero adotado para a comunicação.

Isso quer dizer que os interlocutores, ao concordarem em interagir por meio de determinado gênero, comprometem-se com a manutenção, construção ou reconstrução da imagem de si mesmos, pois “identidades são construídas dentro dos espaços sociais em desenvolvimento, identificadas por atos comunicativos reconhecíveis” (Bazerman,2005:106).

A entrevista televisiva é um gênero pelo qual os participantes da interação verbal encontram-se preocupados com a imagem veiculada durante o encontro social, principalmente 
aquela divulgada entre os telespectadores. Essa imagem pode ser construída, reforçada ou reformulada.

Goffman (1974, 2004), em seus estudos sobre a representação de si, afirma que, em toda interação verbal, os participantes colocam em ação uma linha de conduta ${ }^{3}$, ou seja, um padrão de atos verbais e não-verbais pelos quais o interactante expressa sua visão sobre a situação e sua avaliação não só dos participantes, mas, especialmente, de si mesmo.

Assim, na entrevista televisiva, temos um entrevistador que assumirá determinada linha e essas informações iniciais projetadas por ele serão utilizadas pelo entrevistado para definir a situação e planejar sua linha de ação, em resposta. Essas linhas de ação poderão sofrer acréscimos ou alterações durante a interação, mas é indispensável que estejam de acordo com as linhas adotadas no início da interação.

Caso ocorra algum fato, no momento da interação, que desacredite ou lance dúvidas sobre a linha adotada por determinado interlocutor, a interação poderá sofrer uma interrupção confusa e embaraçosa. Isso nos permite dizer que na entrevista televisiva, se um dos participantes, entrevistador ou entrevistado, tem sua linha desacreditada, esses poderão se sentir constrangidos, enquanto seus interlocutores poderão tornar-se hostis. A interação, nesse caso, sofre um colapso, em que os interactantes podem-se sentir pouco à vontade, confusos e até mesmo envergonhados.

À medida que progride uma entrevista, entrevistador e entrevistado transmitem tanto a seus interlocutores face a face, quanto a seu telespectador, informações a respeito do que representam socialmente, e como gostariam que seus interlocutores, em geral, entendessem essa representação.

$\mathrm{Na}$ entrevista, os participantes face a face procuram controlar as impressões que seus

\footnotetext{
3 A noção de "linhas de conduta" será retomada, no capítulo 3, para explicarmos os procedimentos de preservação da face.
} 
interlocutores recebem da situação. Esses interactantes procuram transmitir uma imagem associada a valores oficialmente reconhecidos pelo público que assiste ao programa de entrevistas. Deste modo, podemos observar que, numa entrevista televisiva, a preocupação com a imagem transmitida também reflete a cultura e os valores de determinada sociedade, a quem a mídia transmite a entrevista televisiva. Para isso, o interlocutor face a face dissimula ou despreza as atividades, fatos e motivos incompatíveis com a representação assumida naquela determinada interação, em um gênero específico.

Finalmente, encontramos com freqüência atores que alimentam a impressão de ter motivos ideais para assumir o papel que estão representando, que possuem as qualificações ideais para o papel, e que não precisam sofrer quaisquer indignidades, insultos e humilhações, ou fazer "acordos" tácitos para consegui-lo (Goffman, 2004:49).

Dessa forma, o interactante, para manter sua representação, procura aproximar-se dos valores de seu público, e seu relacionamento com a platéia passa a ter um caráter especial e único (op. cit.). Porém, a impressão de realidade criada por uma representação é frágil, delicada e pode ter seu equilíbrio alterado devido a pequenos contratempos ocorridos durante a interação, e o público pode descobrir algo incompatível com a impressão apresentada.

Quando há uma desconfiança da representação de determinado interactante, significa que é colocado em dúvida o direito que o interlocutor tem de representar determinado papel e posição social (op. cit: 60). Assim, o interlocutor precisa prevenir-se para não deixar transparecer desacordos com a representação que sustenta, e sim transmitir uma imagem compatível com valores sociais reconhecidos por seu público.

As características apresentadas até aqui confirmam que as entrevistas podem ser reconhecidas enquanto um gênero, porém, isso não significa que esses elementos sejam os 
únicos capazes de definir o gênero entrevista televisiva. Como já dissemos no início do capítulo, os gêneros estão sempre em transformação, conforme o modo de produção dos meios de comunicação e das manifestações culturais de cada sociedade, o que torna difícil realizarmos uma classificação universal, com características estanques.

Sendo assim, após uma breve explanação sobre algumas características gerais encontradas nas entrevistas televisivas, abordaremos, a seguir, as especificidades que diferenciam o corpus selecionado para a pesquisa - referente às entrevistas veiculadas pelo SBT, durante o Programa Livre - de outras entrevistas televisivas, e que possibilitam aos interlocutores, dentro das regras estabelecidas pela produção do programa, agirem conforme seus objetivos.

1.2.1 Características específicas da entrevista televisiva no "Programa Livre"

Os programas de entrevistas, se quiserem ser reconhecidos como tal, precisam respeitar determinados contratos de comunicação estabelecidos entre os interlocutores e que definem o gênero. Entretanto, é possível encontrarmos programas de entrevistas televisivas que se diferenciam uns dos outros. Isso acontece porque cada programa, ao mesmo tempo em que obedece a certos padrões comunicativos típicos dos gêneros, procuram variáveis as quais possibilitam uma identidade diferenciadora para o programa.

Conforme já exposto anteriormente, no início deste capítulo, a mídia constitui um suporte organizacional que envolve noções de comunicação e informação reunidas sob diversas lógicas - econômica, tecnológica e simbólica (Charaudeau, 2006). Desta maneira, quando observamos as características que definem a entrevista no Programa Livre, como uma 
entrevista televisiva, constatamos uma lógica econômica em que um produto de informação é criado para auxiliar na construção de representações e valores sociais, de um determinado público-alvo (lógica simbólica), a ser atingido pela televisão, mídia em que é difundido o programa (lógica tecnológica).

Essas lógicas que determinam os objetivos de um programa interferem nas características do gênero: ao invés de entrevistadores especialistas, temos a presença de entrevistadores jovens, escolhidos na platéia para realizarem suas perguntas. Cria-se, assim, um elo de identificação entre os participantes da entrevista e o público-alvo que assiste (telespectadores) ao programa.

No que se refere à disposição física dos participantes da entrevista, temos um entrevistado que se encontra sentado numa cadeira giratória, em meio a um auditório interno ${ }^{4}$. A apresentação do programa é realizada pelo mediador Sérgio Groisman, que anda pelo estúdio à procura de pessoas as quais queiram realizar perguntas ao entrevistado. A transmissão da entrevista ocorre ao vivo ${ }^{5}$ e todas as imagens transmitidas ao telespectador podem ser acompanhadas pelos participantes, no estúdio, por meio de um telão, localizado atrás do entrevistado.

O auditório interno é composto por jovens estudantes de cursinhos, escolas de ensino médio e faculdades que são anunciadas logo na abertura do programa. Assim como a platéia presente no estúdio, os telespectadores também são, na maioria, jovens que se identificavam com o formato do programa.

Essa constitui uma das principais peculiaridades dessa entrevista: os entrevistadores são pessoas não especializadas, e ora fazem parte da platéia, ora são entrevistadores. Nesse

4 Designaremos platéia o auditório que se encontra no estúdio de gravação e telespectadores o público que assiste ao programa.

5 Algumas entrevistas do Programa Livre não foram transmitidas ao vivo, porém, a entrevista selecionada para o corpus da pesquisa foi anunciada como uma transmissão realizada ao vivo. 
ponto, observamos que a entrevista marca-se por uma interação que envolve entrevistado, mediador e entrevistadores - formato não usual aos programas de entrevistas.

Assim, quando o entrevistado conclui sua resposta, não temos o enunciado do entrevistador logo a seguir, mas sim a procura realizada pelo mediador Sérgio Groisman que sinaliza com o enunciado “Quem? Quem? Quem?”, o momento em que está selecionando o entrevistador e, por meio da expressão "Fala Garoto", ele repassa o microfone e autoriza o entrevistado escolhido a realizar sua pergunta.

No programa em questão, verificamos que vinte perguntas são realizadas pela platéia, enquanto o mediador produz somente cinco. Essa diferença ocorre, provavelmente, porque uma das principais características dessa entrevista, e que a diferencia da maioria das outras entrevistas televisivas, é a possibilidade de assistirmos aos integrantes da platéia, entrevistadores não especializados, realizarem sua perguntas. Desta maneira, a expectativa não está nas perguntas elaboradas pelo mediador, representante dos interesses da emissora em que o programa é transmitido; e sim nas perguntas organizadas pelos entrevistadores que correspondem ao auditório presente, próximo em termos de espaço físico.

Alguns programas de entrevistas admitem perguntas realizadas pelos telespectadores através de cartas, e-mails ou telefonemas, porém, essas perguntas são primeiramente avaliadas pela produção antes de serem repassadas diretamente ao entrevistado. No Programa Livre, não ocorre essa seleção, pois o mediador escolhe o entrevistador e não a pergunta. ${ }^{6}$

Essas peculiaridades da entrevista transmitida no Programa Livre só conseguem se concretizar porque os participantes aceitam as condições de interação determinadas por um acordo, em que negociam os papéis discursivos e sociais ao se expressarem através de determinado gênero. Isso quer dizer que os participantes da entrevista já conhecem as

6 Como pesquisadora, em dado momento, foi possível participar do Programa Livre e fazer parte do auditório. Assim, registramos como ocorre a seleção dos entrevistadores, in locu. 
caraterísticas de tal gênero e estabelecem um contrato de comunicação inicial em que aceitam interagir, conforme essas regras pré-estabelecidas (Charaudeau, 2006).

A seguir, para melhor elucidar os conceitos abordados, indicaremos alguns exemplos obtidos do corpus destinado à pesquisa, que se refere à entrevista televisiva do Programa Livre, veiculada pelo SBT.

1.2.1.1 Dados da interação no "Programa Livre"

Algumas regras do contrato de comunicação podem ser modificadas durante a interação, segundo os objetivos de cada interlocutor. No exemplo a seguir (A), o entrevistador L15, (linhas 493 a 535), após um longo turno em que aproxima a imagem do entrevistado Collor (L2) às oligarquias do nordeste, realiza sua pergunta e, ao invés de passar o turno para o entrevistado responder, transfere-o para outro entrevistador, L16, que realizará outra pergunta:

(Exemplo A)

L15: $\quad$ (...) eu quero saber VOCÊ entende? partindo dessa base eleitoral que é o nordeste... como é que você pensando em fazer algumas mudanças e:: com esses interesses... só pra complementar ((entrega o microfone a L16, que está a seu lado))

L16: ó... você falou aqui... que::.... ó... algumas é... incoerências aqui no seu discurso tá... (...) aí eu que/queria fa/falar eu queria que você ((gritos do auditório)) respondesse pra mim... eu queria se você não tem medo que /com a elite contínua no governo Brasil democrática com essa falsa democracia que governa hoje... o:*:: movimento sem terra se armar por exemplo... como se armaram os exércitos... de libertação da Colômbia se armarem... e provocar uma guerra civil no Brasil ((aplausos e gritos))

O trecho acima indica que o contrato de comunicação estabelecido entre os participantes do programa sofre uma quebra, pois ao realizar a pergunta, o entrevistador L15 
não cede o turno ao entrevistado e transgride uma das normas do programa, ao passar o turno diretamente a outro entrevistador, L16, sem autorização do mediador (linha 495).

Nessa entrevista, o par perguntas-repostas sofre uma alteração, pois é intermediado por pequenas interrupções do mediador, ao procurar na platéia o entrevistador. Deste modo, no exemplo A, o entrevistador não somente provoca uma quebra ao ignorar a função do mediador, mas também ocasiona uma alteração no par pergunta-resposta, ao possibilitar a elaboração de uma pergunta seguida de outra.

Os entrevistados, por sua vez, preocupam-se em atingir as expectativas dos telespectadores e a aprovação da platéia, que em vários momentos manifesta sua satisfação ou insatisfação através de gritos, palmas e vaias.

Como os entrevistadores não são especialistas em política, seus conhecimentos são aqueles adquiridos no ambiente escolar ou, muitas vezes, transmitidos pelos pais, que presenciaram os escândalos políticos na época em que Collor foi presidente. Sendo assim, procuram mostrar-se atualizados com os acontecimentos políticos ocorridos no país, ao elaborarem suas perguntas, o que nos possibilita observar alguns turnos de entrevistadores tão grandes quanto os do entrevistado. É o que ocorre com os interlocutores L15 e L16, no exemplo anterior: “ó... você falou aqui... que::.... ó... algumas é... incoerências aqui no seu discurso tá...(...)” (linhas 496 e 497); “aí eu que/queria fa/falar eu queria que você” (linha 530).

Apesar de alguns momentos, como o citado no exemplo A, verificarmos que não houve assimetria na interação entre o entrevistador e o entrevistado, devido aos longos turnos de ambos, não podemos dizer que essa entrevista seja simétrica, pois a maioria dos entrevistadores elaboram perguntas que dominam pouco tempo do turno, se comparadas com os longos turnos utilizados pelo entrevistado para as repostas. 
Durante o enunciado das questões, constatamos que alguns entrevistadores lêem anotações, assim como o mediador, no início do programa, também deixa à vista um papel em que obtêm as informações para apresentar o convidado. Entretanto, apesar de alguns entrevistadores deixarem explícito, através das imagens, que planejam suas perguntas, observamos uma grande ocorrência de características da língua falada, próprias de uma conversação espontânea, como hesitações, repetições e correções. No exemplo anterior (A), as anotações expostas de L16 não evitaram as marcas de uma língua falada.

Devido à transmissão ao vivo, não houve o momento de edição, porém, isso não nos permite dizer que o telespectador tivesse acesso a todas as informações discutidas no Programa, porque a própria filmagem corresponde a uma seleção realizada pela equipe de gravação do programa.

Vejamos, no exemplo a seguir, a resposta do entrevistado, Collor (L2, linha 331), a uma pergunta que o telespectador não consegue ouví-la (linha 330) e não consegue visualizar quem a realizou, porque a cena em que ocorre a pergunta não foi filmada. Assim, somente quem estava presente no estúdio pôde acompanhar o que de fato foi enunciado e quem foi o enunciador.

(Exemplo B)

L2: veja que:: ((gritos do auditório)) você me atribui um poder de persuasão que eu não sei se tenho... o que eu sei que tenho

$330 \mathrm{~L}(?)$ :

(incompreensível)

L2:

se tenho obrigado ((risada do locutor e aplausos do auditório)) (...) 
Também não podemos deixar de destacar que o entrevistado precisa se preparar, anteriormente, para transmitir aos telespectadores a imagem de si condizente com seus objetivos. Para isso, ele precisa conhecer as características da entrevista da qual participará e o perfil de seus entrevistadores. O mediador, por sua vez, também precisa estar informado e preparado para direcionar as perguntas, caso não estejam de acordo com os objetivos da produção do programa.

Deste modo, entrevistadores, mediador e entrevistado possuem um preocupação com os anseios do telespectador que acaba por influenciar, juntamente com a mídia em que ocorre a entrevista - televisão- a direção que ela deve seguir e os valores que estão em jogo no momento da interação (Barros, 1991).

No caso da entrevista analisada, não somente o telespectador exerce uma influência nos discursos dos participantes da interação, mas também a platéia presente no estúdio. Estes, como já foi exposto, manifestam-se por meio de expressões de acordo ou desacordo com o enunciado dos interlocutores.

É importante notarmos que a relação discursiva entre a platéia e o entrevistado podem sofrer alterações, pois os integrantes da platéia podem completar, retificar e lançar argumentos quanto ao que foi enunciado pelo interlocutor. Vejamos o exemplo das linhas 541 a 552, em que Collor (L2) é interrompido por um interlocutor pertencente à platéia.

(Exemplo C)

L2: (...) a minha família... não é uma família que é:: a gente pode chamar de oligárquica

L?: C(incompreensível)

L2:

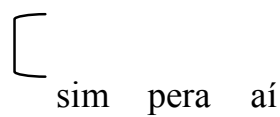




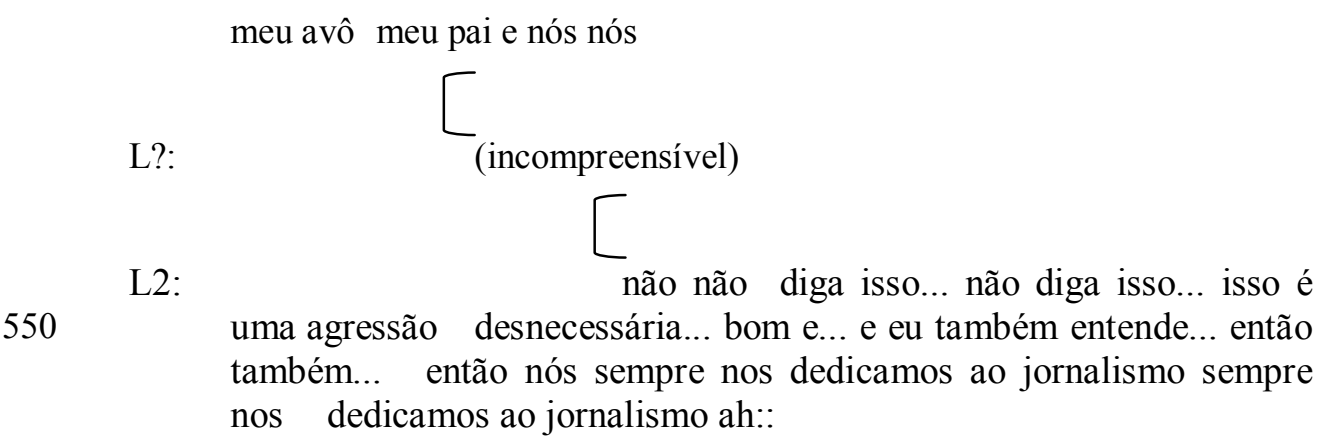

Já a relação entre o telespectador e o entrevistado não pode sofrer essas alterações, pois não constitui uma interação em que estejam no mesmo espaço físico.

O entrevistado e os entrevistadores que fazem parte também da platéia, ao expressarem suas ideologias e concepções de uma sociedade, aproximam a entrevista de um pólo mais contratual ou um pólo mais polêmico e procuram compartilhar esses ideais com os telespectadores, ganhando, assim, a aprovação quanto à direção escolhida para a entrevista.

A entrevista sob análise aproxima-se do pólo mais polêmico, em que os interactantes, considerando seus papéis discursivos e sociais dentro de um determinado contexto, ameaçam destruir a imagem que seus interlocutores tentam construir ou reconstruir perante o público constituído pelos telespectadores e pela platéia presente no estúdio.

A própria interação implica uma certa disputa, já que se rompe um equilíbrio inicial e um processo de negociações, trocas, normas partilhadas e concessões são colocadas em prática até que se restabeleça o equilíbrio, ou, até mesmo, em alguns casos, que se chegue à conclusão de que não há possibilidade de se restabelecer o equilíbrio (Aquino, 1997). Essas negociações entre os interlocutores dependem das competências e intenções de cada um deles e da combinação entre elas durante a conversação.

Dessa forma, apesar da existência de contratos que determinam as regras da comunicação, os participantes de uma interação não estão completamente presos a eles, pois 
possuem um modo de expressão próprio, que constituem suas escolhas individuais de estratégias conforme seus objetivos na conversação:

Contrato de comunicação e projeto de fala se completam, o primeiro, por suas restrições situacionais e discursivas, o segundo, pela escolha de estratégias individuais. Ambos fazem com que todo ato de linguagem seja um ato de liberdade, mas uma liberdade vigiada (Charaudeau, 2006:71).

Conforme já havíamos relatado, os participantes da entrevista televisiva comprometem-se com a manutenção, a construção ou a reconstrução de identidades sociais, considerando-se as características do gênero pelo qual efetivarão a comunicação. Porém, os interactantes, ao se preocuparem com a imagem veiculada entre seus interlocutores, precisam reconhecer um contexto situacional que engloba as normas comunicativas e sociais que compõem um gênero e, principalmente, precisam compartilhar contextos culturais, biográficos e de conhecimento de mundo (Andrade, 2000), como indicamos no capítulo seguinte. 


\section{CAPÍTULO II}

\section{A INTERAÇÃO FACE A FACE NA}

\section{ENTREVISTA TELEVISIVA}


As leituras das obras de Bakhtin têm permitido observar a linguagem como um fenômeno social da interação verbal, realizada através da enunciação ou enunciações. De acordo com essa concepção, a linguagem é associada a um caráter dialógico, em que todo enunciado pressupõe aqueles que o antecederam e todos os que o sucederão. Sendo assim, o autor considera o dialogismo um princípio constitutivo da linguagem, pois "cada enunciado é um elo na corrente complexamente organizada de outros enunciados" (Bakhtin, 2003:272).

A essa concepção sobre a linguagem associa-se a de Koch (2004a: 8-9), que a entende como atividade, como forma de ação. Porém, salienta:

ação inter-individual finalisticamente orientada; como lugar de interação que possibilita aos membros de uma sociedade a prática dos mais diversos tipos de atos, que vão exigir dos semelhantes reações e/ou comportamentos, levando ao estabelecimento de vínculos e compromissos anteriormente inexistentes.

De acordo com esses conceitos, a linguagem é observada e analisada, nesta pesquisa, a partir de indivíduos reais em situações concretas, considerando-se as condições de produção dos enunciados; enfim, a linguagem é estudada em seu momento real, capaz de provocar ações e reações, de construir e/ou reconstruir papéis sociais, de negociar sentidos, de formar identidades, de mudar comportamentos e transformar concepções ideológicas.

A interação, considerada um processo verbal e social, estará presente nas entrevistas, em que encontramos sujeitos que interagem por meio de perguntas e respostas e elaboram seus enunciados, conforme seus objetivos. Ao interagirem, os participantes de uma entrevista têm por objetivo não só a troca de informações, mas também o intuito de compreenderem e de se fazerem compreender. 
Como há revezamento de posições, (entre quem fala e quem interpreta), cada participante de uma interação verbal contribui, parcialmente, no projeto de construção de sentido do outro, ou seja, a interação é uma atividade cooperativa, em que seus interlocutores contribuem para sua elaboração (Brait, 1999).

Porém, para que os interactantes possam colaborar, é necessário que entendam as mensagens transmitidas pelos seus interlocutores e, assim, torna-se essencial o reconhecimento de dados contextuais que informem como o interactante deve compreender e quais as ações deve realizar, a fim de que seja compreendido, de acordo com suas intenções. Deste modo, a interação é um lugar de construção de relações sociais e sentidos.

Isso significa que a interação verbal não pode ser entendida e explicada fora de um contexto, conforme corrobora Brait (1999: 202):

(...) esse contexto interacional não é algo dado previamente, mas uma construção negociada nesse jogo de intersubjetividades e que depende das diferentes competências dos participantes, de seus desejos e de suas intencionalidades, e principalmente da maneira como a interação começa e se desenvolve no intercurso conversacional.

Devido à importância do contexto nos processos de compreensão e produção de enunciados, entendemos ser pertinente que o coloquemos em evidência nesta pesquisa.

2.1 A influência do contexto nas interações face a face

A noção de contexto tem sido estudada por várias áreas do conhecimento (Lingüística, 
Pragmática, Psicologia, Sociolingüística, Etnolingüística) e, segundo Duranti \& Goodwin

(1997:2), isto torna difícil formularmos uma definição de contexto única, precisa e técnica, pois a noção de contexto envolve uma perspectiva bastante restrita e apresenta tratamentos divergentes:

the terms means quite different things within alternative research paradigms, and indeed even within particular traditions seems to be defined more by situaded practice, by use of the concept to work with particular analytic problems, than by formal definition. ${ }^{7}$

Entretanto, essa complexidade exposta pelas diversas teorias aponta para a preocupação e importância do estudo sobre o contexto e sua influência na compreensão das atividades da linguagem. Assim, segundo os autores (op. cit: 2), o contexto pode ser entendido como um enquadre (frame) que envolve o evento examinado e fornece pistas para uma interpretação apropriada.

Isso nos permite dizer que os interactantes interpretam o que está acontecendo com base nas informações de um enquadre interacional e conceitual, o que relaciona os estudos do contexto com uma noção cognitiva que vai além das características físicas de produção ${ }^{8}$. Consideraremos, portanto, nas interações verbais, que informações de ordem social e cognitiva relacionam-se em um processo de compreensão do discurso, ou seja, o

7 O termo significa coisas bastante diferentes dentro de paradigmas de pesquisa alternativos e até mesmo dentro das tradições particulares que parecem ser mais definidas pelas práticas situadas, pelo uso do conceito para trabalhar com problemas analíticos do que com uma definição formal.

8 Malinowski (1923) e Halliday (1978) propõem o conceito de contexto de situação, numa referência às características encontradas no entorno material (cenário, atos e acontecimentos) e que são pertinentes ao discurso produzido. Coseriu (1962) denomina contexto extraverbal o conjunto de circuntâncias nãolingüísticas que, física ou culturalmente, envolvem o ato de enunciação e distingue-os em: contexto físico, contexto empírico, contexto natural, contexto prático ou ocasional, contexto histórico e contexto cultural. Parret (1988), ao estudar os 'tipos' de pragmática, aponta cinco tipos de contextos, a saber: contexto cotextual, contexto existencial, contexto existencial, contexto acional e o contexto psicológico. Apesar da existência de vários contextos, conforme explicitamos brevemente, preferimos delimitar dois contextos em nosso trabalho - o situacional e o cognitivo - devido à relação estabelecida entre estes e a escolha de estratégias discursivas para a reconstrução da imagem. 
conhecimento da situação social e de normas comunicativas, juntamente com informações cognitivas, tais como crenças, opiniões, conhecimentos prévios e enciclopédicos são estrategicamente acionados pelos interactantes com o intuito de compreenderem-se mutuamente.

Desta maneira, numa perspectiva sociointeracional, Gumperz (1997:230) considera que "a noção de contextualização precisa ser entendida com referência a uma teoria da interpretação" e, numa noção mais dinâmica de contexto, propõe uma propriedade de "mão dupla", no sentido de que o uso lingüístico tanto reflete (situa a produção discursiva) como produz contextos (é gerado no processo comunicativo). Assim, a relação entre discurso e contexto se baseia num duplo movimento, em que o discurso é condicionado pelo contexto, ao mesmo tempo em que pode transformar esse mesmo contexto, durante uma interação verbal.

Numa perspectiva cognitiva, Van Dijk (2004) comenta que o contexto envolve o processamento e interpretação de informações exteriores e o uso de informações internas e cognitivas. Posteriormente, o mesmo autor (Van Dijk, 2005) complementa essa informação ao atribuir ao contexto categorias as quais definem as condições físicas de sua produção, como a definição global da situação, a localização (tempo e espaço), as ações em curso (discursos e gêneros do discurso), os vários papéis dos participantes da interação (comunicativo, social e institucional); e categorias que definem representações mentais como finalidades, conhecimento, opiniões, atitudes e ideologias.

Ainda, segundo esse estudioso (2005: 24),

(...) controlar o contexto implica controlar uma ou mais destas categorias, determinar a definição da situação comunicativa, decidir o tempo e o espaço do evento comunicativo ou onde os participantes podem ou devem estar presentes, e em que papéis, ou decidir que conhecimentos ou opiniões eles devem (não) ter e que tipo de ações sociais podem ou devem ser realizadas 
pelo discurso.

Assim, ao abordar as características do contexto, Van Dijk (2005) propõe o estudo de modelos mentais que fornecem as informações relevantes para a produção e compreensão de enunciados. Esses modelos constituem representações cognitivas de experiências pessoais relativas a ações, acontecimentos ou situações particulares, localizados na memória episódica. $^{9}$

Isso significa que nossos conhecimentos, obtidos de experiências anteriores e os quais utilizamos para preencher as informações não explicitadas durante a interação, com o intuito de produzirmos ou entendermos os enunciados de acordo com os propósitos dos interactantes, são armazenados na memória.

Deste modo, os interactantes, numa interação verbal, constroem modelos mentais não só da situação em que interagem (modelos contextuais), como também dos acontecimentos ou situações sobre as quais falam (modelos de acontecimentos). Conforme Van Dijk (2005:52):

Os modelos contextuais e modelos de acontecimentos são representações mentais na memória episódica, quer dizer, a parte da memória de longo prazo onde as pessoas armazenam o seu conhecimento e opiniões sobre episódios em que participam ou sobre os quais lêem/escrevem. Os modelos mentais consistem provavelmente numa representação esquemática das dimensões pessoal e socialmente relevantes dos acontecimentos, tais como localização (espacial, temporal), participantes (em vários papéis), ações e outras.

Nesse sentido, a compreensão de um discurso depende da construção de um modelo

9 Segundo Kato (1993:52), existem três tipos de memórias: a de curto termo, onde armazenamos uma quantidade limitada de seqüências de números ou de palavras; a de médio termo ou operacional, que comporta o conteúdo proposicional, ou seja, as unidades lógicas de significado; e a de longo prazo, onde são guardadas as informações mais permanentes, como o conhecimento lingüístico e o conhecimento de mundo. $\mathrm{Na}$ memória de longo termo é que encontramos a memória episódica, onde ficam registrados os fatos particulares vivenciados pelo indivíduo, e a memória semântica, onde se encontram as informações adquiridas pela transmissão do saber, seja através da escrita, do som ou da visão. 
mental para o mesmo. Esses modelos constituem um elo que une as representações sociais de um grupo social, os modelos mentais de seus membros e o discurso desses: "as representações sociais são 'particularizadas' em modelos mentais e são expressas no texto e na fala frequentemente através de modelos mentais." (Van Dijk, 2005:53). É através de modelos mentais do discurso quotidiano, como conversações, que "adquirimos nosso conhecimento sobre o mundo, as nossas atitudes socialmente partilhadas e, por último, as nossas ideologias e normas fundamentais e valores" (op.cit). Sendo assim, instâncias particulares de conhecimento e de opiniões partilhadas socialmente integram os modelos mentais.

Por outro lado, as representações sociais também são abstraídas do conhecimento pessoal e, ao sofrerem um processo de generalização, adaptação e normatização, constituem cognições partilhadas por todos ou pela maioria dos membros de um grupo; elas são adquiridas, mudadas e usadas em situações sociais. Nesse sentido,

à semelhança da interface entre cognição social e cognição pessoal, os modelos são representações mentais utilizadas para uma análise (produção discursiva ou compreensão) nos dois sentidos. Por um lado, instanciam e aplicam cognições sociais em situações específicas, pessoais. Por outro lado, constituem a base experimental de processos de generalização, abstração e descontextualização, inerentes à formação do conhecimento e de atitudes, comuns a membros de grupos. (Van Dijk, 2005:147)

O modelo contextual contém informações sobre os objetivos do discurso, os atos comunicativos e as características da audiência, ou seja, esse modelo controla aspectos interacionais e comunicativos do discurso e relaciona o discurso com situações sociais e estruturas (Van Dijk, 2005: 70). É esse modelo que controla a informação do modelo de acontecimento relevante para o enunciado: enquanto os modelos de acontecimentos representam aquilo que é comunicado, os modelos contextuais regulam como essa comunicação é realizada (op. cit:193). 
É preciso destacar, dada sua importância, os conceitos de dois modelos cognitivos responsáveis pelos conhecimentos de mundo necessários à compreensão e que se relacionam com o contexto, construído e interpretado durante a conversação: os esquemas e enquadres.

\subsection{Esquemas e enquadres}

Entre os autores que se preocuparam com os elementos estruturais da situação de fala, destacamos Gregory Bateson (2002) e seus estudos sobre enquadres, Deborah Tannen (2002), que trabalhou com as questões relacionadas à construção e interpretação de significados e Goffman (2002), com seu conceito sobre footing e rituais conversacionais.

Para Bateson (2002), os interlocutores estão preocupados em identificar sinais que contextualizam os enquadres, a fim de que possam fornecer uma resposta adequada à situação presente e contribuir com mais eficiência na construção da comunicação em curso - para identificarmos se um enunciado é uma brincadeira ou uma ironia, precisamos identificar pistas, durante a interação, que possibilitem a interpretação de acordo com as intenções do locutor; porém, nem todas as pistas servem para interpretar um evento - é o caso da ironia, em que o sinal verbal pode não dar pistas ao interlocutor de que a situação não deve ser entendida como uma brincadeira.

Dessa forma, para entendermos se o enunciado é, de fato, uma brincadeira, ou ironia, precisamos selecionar, entre os sinais, aqueles que devem ser incluídos e atuam como premissas para a interpretação de um evento. Esses sinais constituem metamensagens que, implicitamente, fornecem instruções de como o interlocutor deve interpretar e/ou produzir um enunciado. $\mathrm{O}$ enquadre seria, dessa maneira, o resultado do uso de premissas ou 
metamensagens que orienta a compreensão do enunciado.

Tannen (1979) considera que o enquadre, enquanto resultado de premissas, também deve ser o resultado de conhecimentos prévios compartilhados. A autora propõe o conceito de estruturas de expectativa, isto é, conhecimentos adquiridos pelas pessoas através de experiências anteriores e que são compartilhados em determinada sociedade. Esses conhecimentos compartilhados é que nos possibilitam realizar associações e inferências sobre pessoas e acontecimentos durante uma interação.

Ao interagirem verbalmente, os interactantes acionam sinais indicadores das estruturas de conhecimento que devem ser utilizadas para compreenderem um determinado enunciado. Nessa perspectiva, podemos dizer que a interpretação ocorre em função da seleção e sinalização de certas estruturas de expectativa.

Tannen e Wallat (2002) distingem duas estruturas de expectativas: os enquadres interativos e os esquemas de conhecimento. A primeira categoria, enquadre interativo, referese à interpretação feita pelo interactante, a respeito do que acontece em uma interação; ocorre quando um interactante constrói o sentido referente ao que está sendo feito em uma interação. Ele "situa a metamensagem contida em todo o enunciado, sinalizando o que dizemos ou fazemos, ou como interpretamos o que é dito e feito.” (Ribeiro e Garcez, 2002:107).

A segunda categoria, "estrutura de conhecimento", conhecida como esquemas, referese às expectativas dos interactantes em relação às pessoas, objetos, cenários e modos de interação. É o conhecimento de experiências anteriores que auxiliam no entendimento do significado de uma elocução. Essas experiências anteriores é que nos possibilitam preencher informações não proferidas no enunciado.

Por exemplo, no caso do nosso corpus, para entendermos os enunciados produzidos, precisamos ter armazenados, em nossa memória, os esquemas de conhecimento que nos 
permitam associar o que está sendo enquadrado com os acontecimentos que ocorreram no passado político do país. Assim, na pergunta realizada por L3, abaixo (linhas 34 a 37), verificamos a necessidade de interactantes buscarem esquemas de conhecimento, armazenados em suas memórias, que lhes informem aquilo que não está expresso no enunciado, como o significado de impeachment e os acontecimentos relacionados a esse processo, ocorridos na época em que o entrevistado, Fernando Collor de Melo, elegeu-se Presidente do Brasil.

(Exemplo D) 35

L3: Rodrigo do Colégio Arbes... o senhor acredita que foi julgado e condenado por que estava num partido de menor poder político? assim... se o Sr. estivesse num PMDB ou num PFL se não... não seria condenado... no impeachment?

Entretanto, podem ocorrer situações interacionais em que os participantes tenham diferentes esquemas, ocasionando, assim, mal-entendidos ou até mesmo uma mudança nos enquadres interativos: "quando os participantes têm diferentes esquemas, o resultado pode ser confusão, conversa cruzada e, com freqüência, o surgimento de mudança nos enquadres interativos.” (Tannen e Walltat, 2002:206)

Ao observarmos nosso corpus, destacamos o segmento em que verificamos que a entrevistadora propõe um enquadre "edição do debate entre Lula e Collor realizada pelo Jornal Nacional", conforme seu esquema acionado, e o entrevistado manifesta desconhecimento, ou seja, seu esquema não é o mesmo da entrevistadora e, por isso, ele não reconhece o enquadre proposto por ela (linhas 367 a 371 e 408 a 417).

(Exemplo E) 
L13 já que tava falando de manipulação... eu queria saber se... você não acha que se não tivesse sido tão ajudado pela Rede Globo... principalmente no seu último debate com o Lula que foi editado para ser passado no Jornal 370 Nacional se o senhor teria ganhado as eleições? ((gritos e aplausos do auditório))

L2

(...) é difícil haver manipulação quando a transmissão é ao vivo... que manipulação pode haver?... nenhuma

L13 mas a edição que eu estou falando é::um resumo que foi feito pra ser passado no Jornal Nacional... eles fizeram um resumo de seis minutos... que passou::: praticamente :: um minuto a mais do senhor falando que o Collor/que o Lula

Ao indicar que não reconheceu o enquadre proposto por L13, o entrevistado não responde satisfatoriamente, conforme o esperado pelo entrevistador L13.

A distinção entre os enquadres interativos e os esquemas de conhecimento proposta por Tannen e Wallat (2002) possibilita-nos analisar as interações tanto numa perspectiva interacional, em que os interactantes sinalizam e negociam mudanças contextuais, quanto numa perspectiva de sentido, em que os interactantes adquirem e utilizam conhecimentos prévios para associarem a situações comunicativas, com o intuito de interpretarem e fazer compreender os enunciados.

Nas interações, os interactantes estão sempre propondo ou mantendo enquadres, que orientam e organizam o discurso em relação ao contexto. Isso nos permite observar que há uma ligação entre os esquemas (esquemas de conhecimento) e os enquadres interativos, pois o interactante precisa estabelecer relações entre o enquadre definido em determinada interação e seus conhecimentos adquiridos em experiências anteriores (esquemas), para que possa, enfim, interpretar o que está sendo comunicado.

Com o intuito de indicarem como os interactantes enquadram os eventos, as autoras (op. cit) recorrem às pistas e aos marcadores lingüísticos, numa tentativa de explicarem as 
mudanças de enquadres por meio de uma base estrutural, ou seja, através das mudanças de footing.

2.3 As mudanças de footing e as pistas de contextualização

Ao discutir o conceito de footing, Silva (2003:188) o define como uma questão situacional presente na interação e que designa "a sinalização das mudanças na projeção de identidade ou na orientação dos participantes em relação uns aos outros e em relação ao processo interacional".

Sendo assim, o footing é um alinhamento, uma postura, uma projeção pessoal em relação ao outro interactante, a si mesmo e ao discurso em construção (Goffman, 2002). Uma mudança do footing acarreta uma mudança no alinhamento assumido pelos interactantes, expressa na maneira como conduzimos a produção ou a recepção de uma elocução, isto é, ao detectarmos uma mudança de footing, encontramos também uma mudança no enquadre.

Entendido desse modo, constituem o aspecto dinâmico dos enquadres e, principalmente, a sua natureza discursiva. Numa situação face a face, os footings são “introduzidos, negociados, ratificados (ou não), co-sustentados e modificados na interação." (op. cit:107)

Assim, cada enquadre interativo faz com que o interactante estabeleça um footing distinto, isto é, os participantes de uma interação procuram um alinhamento para si e para os outros participantes, conforme o enquadre estabelecido. Se houver uma mudança de enquadre, esses participantes precisam se alinhar novamente, de acordo com a nova situação estabelecida, ou seja, precisam provocar um footing. 
A esse respeito, Aquino (2005:175) destaca:

A percepção do alinhamento, enquadres e de suas dinâmica auxiliam na formulação dos enunciados imediatos e na compreensão das metamensagens que devem ser recuperadas pelos interlocutores durante a organização do discurso do qual participam.

Isso quer dizer que, se a cada mudança de enquadre ocorrer uma mudança de footing, as pistas e marcadores que sinalizam as mudanças de footing podem também nos auxiliar na observação das mudanças de enquadres, ou seja, para entender os objetivos do locutor ao produzir uma elocução, o interlocutor precisa reconhecer marcas no discurso que sinalizem a mudança de footing, chamadas, por Gumperz (2002:152), pistas de contextualização, e assim entendidas :

(...) é através de constelações de traços presentes na estrutura da superfície das mensagens que os falantes sinalizam e os ouvintes interpretam qual é a atividade que está ocorrendo, como o conteúdo semântico deve ser entendido e como cada oração se relaciona ao que se precede ou sucede. Tais traços são denominados pistas de contextualização.

É possível dizer, a partir do exposto, que os participantes de uma interação verbal utilizam pistas de natureza sociolingüística tanto para sinalizarem seus propósitos comunicativos, quanto para inferirem os propósitos conversacionais de seus interlocutores. São pistas lingüísticas, as alternâncias de código, de dialeto ou de estilo, as escolhas lexicais e sintáticas, expressões pré-formuladas, aberturas e fechamentos conversacionais; pistas paralingüísticas, o valor das pausas, o tempo da fala, as hesitações; pistas prosódicas, a entoação, o acento, o tom; e pistas não-verbais, o direcionamento do olhar, o distanciamento 
entre os interlocutores e suas posturas, os gestos.

Dessa forma, consideraremos que o footing só pode ser identificado pelo interlocutor se este perceber as pistas lingüísticas sinalizadas pelo locutor, as quais o conduzirão a interpretar o contexto em que ocorre o evento.

Gumperz (2002:152) considera que as pistas de contextualização só podem ser estudadas dentro de um contexto, visto que fazem parte do processo interativo. Quando ocorrem, mudam o caráter do que aconteceu anteriormente e remodelam todo o curso de uma interação. Assim como diferentes esquemas e enquadres podem ocasionar mal-entendidos, o não reconhecimento da função de uma das pistas de contextualização pode, também, provocar uma divergência de interpretação.

Isso equivale a dizer que, uma mudança de enquadre implica na utilização de pistas de contextualização que auxiliarão o interactante a relacionar a nova situação proposta com seus esquemas de conhecimentos e, uma vez estabelecida esta relação, o interactante assume uma nova postura, um novo alinhamento diante do novo enquadre, ou seja, uma mudança de footing é ocasionada. Porém, como já explicamos, se o participante da interação não reagir às pistas do novo enquadre ou não associá-lo com seus esquemas de conhecimento, haverá uma falha de compreensão entre os interactantes.

O que expusemos corresponde às relações que unem enquadres, esquemas, footing e pistas de contextualização; entretanto, entendemos que os estudos sobre footing merecem aprofundamento, em razão de sua contribuição para compreensão e produção de enunciados numa interação verbal. Por isso, apresentaremos as bases estruturais definidas por Goffman (2002) para explicar as mudanças de footing, numa perspectiva sociolingüística: a estrutura de participação, o formato de produção e o conceito de encaixamento. 


\subsubsection{As bases estruturais do footing}

Para Goffman (1986), o verbal e o social não podem ser separados, visto que os eventos de interação representam o lugar onde são determinadas a imagem e a ordem social. Sendo assim, na entrevista televisiva, temos a presença de entrevistadores e entrevistados preocupados em construir e/ou reconstruir uma imagem social através da interação verbal.

Nas entrevistas televisivas, podemos observar que os interactantes não só trocam informações mas, ao desempenharem seus papéis discursivos e sociais, constroem juntos o discurso, numa tentativa de influenciar os outros participantes da interação. Deste modo, consideramos "todos os destinatários de uma mensagem, mesmo aqueles que não são tão evidentes, exercem um importante papel no desenvolvimento da interação" (KerbratOrecchioni, 1990: 89).

Um indivíduo que fala pode desempenhar papéis ou funções em relação aos outros participantes da interação. Porém, segundo Goffman (2002), os conceitos falante e ouvinte não são suficientes para explicar as posições de participação e a complexidade dos papéis comunicativos. Assim, ao tratar da estrutura de participação, o autor (op. cit.) aborda questões ligadas ao ouvinte, enquanto o formato de produção, refere-se às questões relacionadas ao falante.

Em relação àquele que acompanha o enunciado do locutor, o indivíduo poderá participar da interação como um ouvinte ratificado (aquele que faz parte da interação) ou nãoratificado (que não faz parte diretamente da interação). Entre os ratificados, há três tipos de status: ouvinte endereçado (a quem a fala é dirigida diretamente), ouvinte não-endereçado (a quem a fala não é dirigida especificamente, mas tem status participativo) e platéia (conjunto 
de ouvintes em contextos institucionais).

Assim, a relação de um dos interactantes com um enunciado é considerada um "status de participação", enquanto a relação de todos os participantes de uma interação com um enunciado é o que Goffman (2002) denomina "estrutura de participação”.

Numa entrevista televisiva, entrevistadores e entrevistado constroem seus enunciados em função das possíveis expectativas de uma platéia, que podem ser testemunhas ao vivo coparticipantes numa mesma ocasião social ou participantes que acompanham o evento social por retransmissão (seja pelo rádio, televisão ou, atualmente, internet).

A platéia, ao vivo, emite sinais de concordância ou discordância em relação aos enunciados, porém, indagações e réplicas diretas devem ser evitadas ou adiadas para o término do discurso (op. cit:127). A platéia por retransmissão não está presente fisicamente no evento social e, por isso, seus membros não podem interagir diretamente com entrevistadores e entrevistados ${ }^{10}$; porém, apesar de não estarem visíveis, suas atitudes são constantemente imaginadas pelos participantes da entrevista, para que possam atingir seus objetivos interacionais.

É importante notar que essas posições estruturais podem se alterar, pois, em uma interação com mais de duas pessoas, alguns de seus participantes podem iniciar uma "comunicação subordinada", ou seja, uma conversa próxima ao local em que acontece a “comunicação dominante”. Goffman (2002) apresenta três possibilidades de "comunicação subordinada" durante uma interação verbal: “jogo paralelo" (entre participantes ratificados), “jogo cruzado" (entre participante ratificados e não-ratificados) e "jogo colateral” (palavras murmuradas entre participantes não-ratificados).

Na proposta de Goffman (2002), o formato de produção é constituído pelos conceitos

10 Só podem interagir de maneira intermediada, como no caso de entrevistas em que a produção do programa seleciona quem, entre os membros da platéia por retransmissão, participará via e-mail, carta ou telefone. 
de animador (quem produz sonoramente o texto), autor (quem produz o conteúdo do texto) e responsável (quem delimita sua posição em relação ao texto, ou seja, aquele que está comprometido com o que as palavras expressam).

Desta maneira, num texto memorizado e recitado em voz alta, é possível que um animador produza sonoramente um enunciado sobre cujas formulações não tenha qualquer responsabilidade, ao mesmo tempo em que transmite opiniões e sentimentos alheios. Já no caso da tradução simultânea de um discurso, encontramos um responsável comprometido com os enunciados, mesmo que estes não tenham sido elaborados por ele. Esses exemplos contribuem para percebemos que o termo falante não é suficiente para diferenciar o papel de animador, autor e responsável.

A possibilidade de alternância dessas posições contribuirá para que os participantes de uma interação percebam a mudança de footing: uma nova projeção de identidade será realizada. Porém, essas estruturas e formatos só contemplam questões sociológicas de uma base estrutural para a análise de footing e, para que possamos proceder a um estudo lingüístico que englobe também questões do caráter auto-referencial e independente do discurso, Goffman (2002: 136) propõe um exame dos encaixamentos nas construções dos enunciados.

Segundo esse estudioso, ao analisar as variações nos formatos de produção, o animador, em seu discurso, pode citar o que ele próprio disse, ou o que uma outra pessoa disse, em um momento sobre o qual se está falando. Nesses casos, encontramos dois animadores: um que anima os sons ouvidos, quando ocorre o discurso, e um "animador encaixado", ou seja, uma "figura" encaixada no discurso pertencente ao "universo sobre o qual se está falando"(Goffman, op. cit:139).

Assim, podemos destacar um "eu imediato" que expressa crenças, desejos, percepções de um animador comprometido com seu enunciado. Nessa direção, o exemplo abaixo, 
retirado de nosso corpus, é constituído de um entrevistado (L2) que expressa diretamente sua intenção (linhas 424/425):

(Exemplo F):

L2: nossa senhora pera aí não ((risos))

No segmento anterior (F), localizam-se marcas lingüísticas indicativas da presença imediata de um animador (L2) - "pera aí" - que expressa seu desejo de obter mais cautela, de seu interlocutor, na produção de enunciados.

(Exemplo G):

L2 não não diga isso... não diga isso...

No exemplo $G$, também encontramos um animador (L2) que expressa sua própria vontade através da repetição da expressão "não diga isso" (linha 549).

Nem sempre, porém, encontramos essas construções discursivas, pois, muitas vezes, o interlocutor representa a si mesmo através do emprego de um pronome pessoal "eu", como se fosse uma figura encaixada, alguém que "pertence ao universo sobre o qual se está falando, não ao universo no qual a fala ocorre.” (Goffman, 2002:137). Vejamos exemplos em nosso corpus (linhas 61 e 125 a 128):

(Exemplo H): 
L2: veja que... eu me apresento

(Exemplo I):

L2: (...) eu já tive a idade de vocês... não é eu já estive em colégios secundários eu era líder estudantil era líder é::... na universidade... na época do golpe militar né? eu levei muita pancada... fui preso duas vezes...(...)

Pode ocorrer, também, que um interlocutor encaixe, em seu enunciado, o que um outro indivíduo disse, ou seja, uma terceira pessoa; "pois é tão fácil citar o que outra pessoa disse quanto citar o que nós mesmos dissemos.” (Goffman, 2002:139)

Exemplo J:

L2: (...) e uma vez o Jacques Costeau o Jacques Costeau é:: o comandante 460 ((tossiu)) Jacques Costeau... ((tossiu)) que faleceu recentemente... no ano passado ele chegou pra mim e disse assim ((tossiu)) eu queria lhe fazer um pedido ((pausa prolongada)) que você parasse de andar de jet ski...

No exemplo anterior (linhas 459 a 462), o interlocutor L2 utiliza o pronome "ele" para encaixar o enunciado de um outro indivíduo (Jacques Costeau) dentro de seu discurso; porém, numa análise mais cuidadosa, percebemos que o pronome “eu”, ao invés de representar L2, refere-se, também, ao enunciado da terceira pessoa - Jacques Costeau.

Logo, quando optamos por citar em nosso discurso o que foi dito por outra pessoa, provocamos uma mudança em nosso footing: "Pois, obviamente, quando em vez de dizermos algo nós mesmos, optamos pelo relato do que o outro disse, estamos mudando nosso footing." (Goffman, 2002:141)

Essas explicações sobre enquadres, esquemas e footing possibilita-nos analisar o 
contexto, em interações face a face, a partir de dois aspectos: o primeiro, refere-se às análises dos processos de organização pelos quais os conteúdos mudam de um instante a outro; o segundo, corresponde às observações dos processos de cognição social, por meio dos quais os interactantes monitoram os indicadores verbais e não verbais de tais mudanças (Erickson e Shultz, 2002:234).

Observar o desempenho de identidades sociais e lingüísticas numa interação face a face implica conhecermos como elas se constituem e como alteram o fluxo do discurso e da interação. Sendo assim, não podemos mais nos referir a um falante que possui a única tarefa de produzir o enunciado e um ouvinte que compreende (ou não) o enunciado proferido, pois estaríamos deixando de lado as diferentes relações discursivas que (a estrutura de participação e o formato de produção) contribuem com os propósitos dos interactantes, ao iniciarem uma conversação.

Até o presente momento, observamos as influências do contexto que garantem ou não, uma interação adequada aos propósitos dos interactantes. Porém, as várias informações ativadas na memória a fim de que o interactante compreenda o que diz e o que ouve, são estrategicamente selecionadas, como veremos a seguir.

$2.4 \mathrm{O}$ sistema de estratégias

Conforme Koch (2006: 61), a compreensão só é possível se os interactantes possuírem contextos sociocognivos que sejam, em parte, semelhantes. Isso quer dizer que os 
conhecimentos (conhecimentos lingüísticos, enciclopédicos e sociointeracionais ${ }^{11}$ ) dos interactantes precisam ser parcialmente compartilhados.

A mobilização dos sistemas de conhecimento é realizada através de estratégias de processamento textual. Conforme Van Dijk (2004), “as estratégias são parte de nosso conhecimento geral; elas representam o conhecimento procedural que possuímos sobre compreensão de discurso". Nesse sentido, podemos dizer que a ativação de processos e estratégias, juntamente com a mobilização dos vários sistemas de conhecimento, auxiliam-nos na produção e compreensão de sentidos.

As estratégias são entendidas como instruções globais para cada escolha a ser realizada pelo interactante, na tentativa de compreender um enunciado. Essas estratégias constituem hipóteses operacionais sobre a estrutura e o significado de um enunciado, isto é, os participantes de uma interação verbal realizam passos interpretativos orientados, efetivos, eficientes, flexíveis e extremamente rápidos (Van Dijk, 2004:169). Assim, os interactantes fazem pequenos cortes e podem trabalhar com informações incompletas para chegarem a uma hipótese de interpretação. Essas informações são processadas “on-line”, unidade por unidade.

Deste modo, grupo de palavras, frases e orações são analisados e interpretados, estrategicamente, na memória de curto prazo. Porém, se considerarmos que a memória de curto prazo tem capacidade limitada, seus conteúdos precisam ser transferidos para a memória de longo prazo, lugar onde gradualmente se constrói a representação do enunciado - as interpretações resultantes (provisórias) são estrategicamente relacionadas a modelos de acontecimentos na memória episódica. Isto significa que a compreensão possui um caráter dinâmico e "dialético", visto que a informação do enunciado é interpretada com informação do modelo, ao mesmo tempo em que os modelos armazenam a informação textual.

11 Segundo Koch (2004b), o conhecimento lingüístico corresponde aos conhecimentos gramaticais e lexicais da língua; conhecimento enciclopédico (ou de mundo) envolve qualquer tipo de conhecimento que temos adquirido formalmente ou informalmente, com base em nossas experiências sociais; e o conhecimento sociointeracional refere-se ao conhecimento sobre as ações verbais. 
Koch (2004b) divide as estratégias de processamento textual em:

a- Estratégias cognitivas: as de uso do conhecimento, aquelas que permitem, no momento da compreensão, reconstruir o sentido intencionado (ou não) pelo produtor do texto e outros sentidos também, não previstos ou até mesmo não desejados pelo locutor. Seu uso depende dos propósitos do interlocutor, dos conhecimentos disponíveis a partir do contexto, dos conhecimentos prévios, crenças, opiniões e atitudes. São estratégias de compreensão proposicionais, coerência local, macroestratégias, esquemáticas ou superestruturais; e de produção: estilísticas, retóricas, não-verbais e conversacionais.

Interessa-nos destacar as estratégias retóricas ${ }^{12}$ porque têm por objetivo aumentar a eficácia do discurso e da interação comunicativa (Van Dijk, 2004:33). Elas são usadas para auxiliar na percepção dos propósitos do enunciado e no desempenho e compreensão adequados dos enunciados. Deste modo, não atuam diretamente na construção de representações semânticas, mas operam, paralelamente, com outras estratégias, a fim de auxiliar nesse processo de interpretação.

b- Estratégias interacionais (ou sociointerativas): aquelas que procuram estabelecer, manter e conduzir de forma satisfatória uma interação verbal, são socioculturalmente determinadas e funcionam para estabelecer uma boa interação. Entre elas, estão as estratégias de preservação da face ${ }^{13}$, de atenuação, de polidez e de negociação.

c- Estratégias textualizadoras: as que se referem às escolhas textuais realizadas pelos interlocutores, considerando o sentido que desejam produzir. Elas podem ser consideradas, também, estratégias interacionais e cognitivas. São utilizadas para facilitar a compreensão, introduzir esclarecimentos e/ou exemplificações, aumentar a força retórica do texto, atribuir destaque a certas partes dos enunciados, modalizar o que foi dito e refletir sobre a própria

12 Devido a sua importância para as análises do corpus, no capítulo seguinte, desenvolveremos uma análise mais completa de suas propriedades.

13 Dedicamos também uma análise mais detalhada de suas propriedades no próximo capítulo. 
enunciação.

Até agora, vimos que, para produzirmos e entendermos enunciados, precisamos recorrer aos sistemas de conhecimentos armazenados em nossa memória e ativar estratégias cognitivas e interacionais, as quais possibilitam estabelecer relações entre as informações fornecidas pelos enunciados e as informações contidas em nossos modelos cognitivos.

Como já explicitamos, essas estratégias auxiliam a compreensão e produção de enunciados, conforme os objetivos dos interlocutores. Assim, na interação face a face, tanto as estratégias interacionais, quanto as estratégias retóricas (ou de argumentação) podem contribuir para a construção ou reconstrução da imagem de um sujeito. Ambas estratégias possibilitam uma negociação na tentativa de influenciar o sistema de conhecimento de seus interlocutores e de ajustar diferentes valores sobre determinado assunto.

Visto a importância de tais estratégias, apresentamos, a seguir, um estudo mais detalhado sobre suas influências na constituição da imagem social de um interactante. 


\section{CAPítUlO III}

\section{AS ESTRATÉGIAS DISCURSIVAS}


Destacamos, para nossas análises, o estudo de duas estratégias essenciais para que possamos entender como os participantes de uma interação verbal podem confirmar, construir ou reconstruir uma imagem social, perante seus interlocutores. São elas: as estratégias interacionais, que mobilizam o sistema sociointeracional, e as estratégias argumentativas, que mobilizam o sistema de conhecimento enciclopédico, conforme quadro ilustrativo:

\begin{tabular}{|c|l|l|}
\hline Estratégias & Interacionais & \multicolumn{1}{c|}{ Argumentativas } \\
\hline $\begin{array}{c}\text { Sistema de Conhecimento } \\
\text { mobilizado }\end{array}$ & Sociointeracional & Enciclopédico \\
\hline Finalidade & $\begin{array}{l}\text { Garantir o bom } \\
\text { desempenho de } \\
\text { um evento }\end{array}$ & $\begin{array}{l}\text { Influenciar o sistema de } \\
\text { conhecimento de mundo na tentativa } \\
\text { de mudar a opinião do interlocutor }\end{array}$ \\
\hline
\end{tabular}

$\mathrm{Na}$ tentativa de reconstruir uma imagem, essas estratégias ocorrem conjuntamente, pois, considerado um encontro social, em que os interlocutores interagem face a face, o interactante procura articular estratégias, a fim de preservar sua face e protegê-la de eventuais ameaças; ao mesmo tempo, ele coordena estratégias argumentativas com o intuito de interferir na concepção inicial que seus interlocutores possuem a respeito de sua imagem.

Isso significa que, em situações de interação face a face, onde indivíduos constroem juntos o discurso, numa atividade cooperativa, estratégias cognitivas e interacionais são colocadas em prática, a fim de negociarem a compreensão de suas produções discursivas.

Nesse sentido, faz-se necessária, a seguir, uma abordagem mais destalhada sobre as características e o funcionamento das estratégias interacionais de preservação da face e, posteriormente, das estratégias argumentativas que, juntas, auxiliam na construção da imagem social de um interactante. 
3.1 Estratégias interacionais de preservação da face

As estratégias interacionais, determinadas socioculturalmente, possuem a finalidade de estabelecer, manter e garantir o bom desempenho de um evento, numa interação sem problemas. Entre elas, apresentaremos as estratégias de preservação das faces (faceworks), as quais envolvem estratégias de negociação e de polidez.

Até o momento, verificamos que toda interação é regida por regras conversacionais relativamente flexíveis (Kerbrat-Orecchioni, 2006) que são constantemente negociadas e renegociadas pelos interactantes. É assim que, logo ao iniciarem uma interação, os participantes já se envolvem em negociações que auxiliam na definição de características contextuais da conversação e na construção das relações pessoais que se estabelecem entre os interactantes.

Ao entrarem em contato com outros participantes em um encontro social, seja através de um contato face a face ou mediado, as pessoas tendem a colocar em ação o que Goffman (1974) denomina linha, ou seja, "un canevas d'actes verbaux et non verbaux qui lui (l'individu) sert à exprimer son point de vue sur la situation, et, para là, l'appréciation qu'il porte sur les participants, et en particulier sur lui-même" ${ }^{14}$ (op. cit: 9). Assim, para o autor, face é compreendida como um valor social positivo, o qual a pessoa reclama para si através da linha que os outros presumem ser assumida pela própria pessoa durante um contato específico.

14 Um padrão de atos verbais e não-verbais através dos quais ele (o indivíduo) expressa seu ponto de vista a respeito da situação e da sua avaliação sobre os participantes e, principalmente, de si mesmo. 
Quando uma pessoa segue uma linha que projeta uma imagem consistente de si mesma, apoiada por julgamentos e evidência transmitidos pelos outros participantes, ela tem, está em ou mantém uma face. Porém, em encontros sociais podem ocorrer incidentes que ameacem a face de um dos interactantes, levando-o a selecionar, entre as práticas de salvamento da face constituintes de seu repertório, as mais eficazes para utilizar em uma determinada situação, com o propósito de neutralizar o ato ofensivo e preservar sua face.

O uso de procedimentos para a preservação da auto-imagem (face) pode ser considerado uma tentativa de estabelecer um acordo que garanta o bom desempenho de um evento. Conforme Goffman (1981), existem dois tipos de pressões sofridas por qualquer interação face a face: as comunicativas, responsáveis pela boa transmissão das mensagens, e as rituais, responsáveis pela preservação das faces dos interlocutores. Assim, a natureza humana é construída por regras morais determinadas pela sociedade. Segundo o autor (1974: 42):

Ces règles déterminent l'évaluation personnelle et des autres, la répartition des sentiments et les types de pratiques employées pour maintenir un équilibre rituel d'un genre défini et obligatoire. Il est bien possible que l'aptitude générale à être lié par des règles morales appartienne à l'individu, mais les règles particulières qui font de lui un être humain proviennent des nécessités inhérentes à l'organisation des rencontres sociales. ${ }^{15}$

Para cada papel social vivenciado por um indivíduo, há um diferente ritual em que observamos uma preocupação com a preservação da face, ou seja, com a imagem pública a qual todos possuem e querem que seja preservada.

15 Essas regras determinam a avaliação que fará de si mesmo e dos outros, a distribuição de sentimentos e tipos de práticas empregadas para manter um tipo definido e obrigatório de equilíbrio ritual. A capacidade geral de ser levado por regras morais pode perfeitamente pertencer ao indivíduo, mas as regras específicas que o transforma em um ser humano derivam de exigências estabelecidas pela organização ritual dos encontros sociais. 
Os indivíduos, durante uma interação, precisam cuidar para preservarem sua face e a dos outros interactantes, pois, ao ameaçarem a face do próximo, podem também causar uma ameaça à própria face. Portanto, em uma interação face a face, é estabelecido um estado em que os interactantes aceitem a linha do outro, ou seja, após a tensão provocada pelo encontro social, os interactantes praticam uma negociação, a fim de não ameaçarem mutuamente as faces envolvidas na interação.

Ao neutralizar uma ameaça à face, o interactante precisa estar ciente das interpretações que os outros possam ter a respeito de seus atos, para escolher, entre as práticas habituais de salvamento da face, as mais eficazes.

Um indivíduo possui "face errada"16, sempre que houver uma informação a respeito de seu valor social incompatível com a linha seguida por ele. Caso não possua uma linha pronta, compatível com aquela seguida pelo grupo, dizemos que está "fora da face". O interactante com "face errada" ou "fora da face" pode sentir-se envergonhado e constrangido em contato com os outros, porém, existem aqueles capazes de ocultar esse sentimento: "Suivant 1'usage commun, j'emploierai le terme assurance pour désigner l'aptitude à supprimer et à dissimuler toute tendance à baisser la tetê lors des rencontres avec les autres." (GOFFMAN, 1974:12)

Essa discussão permite compreender que a expressão "perder a face" refere-se ao sujeito que está na "face errada", "fora da face" ou "envergonhado" (shamefaced) e o termo "salvar a face" relaciona-se ao sujeito que sustenta para os outros a impressão de não ter perdido a face.

Existem três níveis de responsabilidade atribuídos à pessoa que provoca uma ameaça à face: em primeiro lugar, o ofensor pode agir por ingenuidade e ocasionar uma ameaça involuntária; em segundo lugar, a ameaça pode ser resultado de malícia ou rancor com o

16 As aspas das expressões "face errada", "fora da face", "perder a face" e "envergonhado" foram indicadas por mim, numa referência às traduções dos termos utilizados pelo autor na versão francesa. 
objetivo claro de provocar um conflito - ameaça premeditada; em terceiro lugar, a ameaça pode ser provocada por ofensas acidentais, ou seja, a pessoa sabe da possibilidade de ameaça à face, mas não o faz por rancor.

Ao discutirem questões referentes à face, Brown e Levinson (1994) afirmam que todo indivíduo social possui:

a- uma Face Positiva: relacionada à necessidade de ser reconhecido e aprovado socialmente.

b- uma Face Negativa: relacionada ao desejo de não ter seu território pessoal invadido, de atuar com liberdade, sem ser coagido. ${ }^{17}$

Nas interações verbais, existem atos que podem colocar em risco a imagem pública tanto do locutor quanto do interlocutor. Esses atos ameaçadores da face são denominados FTAs (face threatening acts) e divididos em quatro categorias por Brown e Levinson (1994);

a- Atos que ameaçam a face negativa do ouvinte: ordem, conselho, ameaça, aviso.

b- Atos que ameaçam a face positiva do ouvinte: reclamação, crítica, desaprovação.

c- Atos que ameaçam a face negativa do falante: aprovação de uma oferta, aceitação ou expressão de um agradecimento.

d- Atos que ameaçam a face positiva do falante: auto-humilhação, confissão e admissão de responsabilidade, desculpas.

A autora Kerbrat-Orecchioni (1992) nota que, nas interações verbais, um mesmo ato pode produzir efeito, simultaneamente, em diferentes categorias. Isso significa que a confissão ameaça, ao mesmo tempo, a face negativa (correspondente ao conhecimento) e a

17 Segundo Kerbrat-Orecchioni (1992b:167-168), o termo "face negativa", utilizado por Brown e Levinson corresponde à noção dos "territórios do eu”, empregada por Goffman, numa referência ao território corporal, espacial ou temporal; aos bens materiais e conhecimentos. Já a "face positiva" corresponde, grosso modo, ao narcisismo e "ao conjunto de imagens valorizantes que os interlocutores constroem de si mesmos e tentam impor durante a interação" (op. cit: 168). 
face positiva do locutor; e a ordem provoca uma ameaça às duas faces (positiva e negativa) do interlocutor.

Como pudemos perceber, ao mesmo tempo em que os interactantes são alvos de ameaças às faces, eles possuem o desejo de preservá-las e, para isso, utilizam procedimentos, a fim de amenizar ou restaurar a face ameaçada, ou seja, procuram realizar um trabalho de figuração (face-works).

Conforme estudos de Goffman (1974:15):

Par figuration (face-work) j'entends désigner tout ce qu'entreprend une personne pour que ses actions ne fassent perdre la face à personne (y compris elle-même). La figuration sert à parer aux $<<$ incidents $>>$, c'està-dire aux événements dont les implications symboliques sont effectivement un danger pour la face. ${ }^{18}$

3.1.1 As práticas de salvamento da face (face-work)

Durante uma interação, os indivíduos possuem dois pontos de vista: um defensivo, com o objetivo de preservar a própria face, e um protetor, uma preocupação em preservar a face do outro. As práticas de salvamento da face (face-work) geralmente são defensivas e protetoras ao mesmo tempo, porém, em algumas situações, tendem a ser mais defensivas ou mais protetoras. Ao tentar salvar a face do outro, é preciso cuidar para não perder a própria face e, ao salvar a própria face, deve-se atentar para o risco de ameaçar a face alheia.

Procedimentos de atenuação podem ser utilizados para evitar os efeitos de uma

18 Por elaboração da face pretendo designar todas as ações pelas quais uma pessoa é capaz de tornar qualquer coisa que esteja fazendo consistente com a face. Esta elaboração serve para contrabalançar incidentes, quer dizer, os eventos cujas implicações simbólicas são efetivamente uma ameaça à face. 
ameaça à face de um interactante, porém, uma vez realizada a ameaça e reconhecida publicamente, temos o status de "incidente" (Goffman, 1974), em que uma série de movimentos corretivos é realizada, a fim de minimizar a tensão na interação social e retornar ao equilíbrio ritual.

Além do evento que introduz a necessidade do intercâmbio ${ }^{19}$ corretivo, os estudos de Goffman (1974) apontam para quatro movimentos clássicos que podem ocorrer: desafio (consiste em chamar a atenção para a conduta desviante); oferenda (movimento que oferece ao ofensor a chance de corrigir a ofensa e de restabelecer a ordem expressiva); aceitação (a oferenda pode ser aceita como uma forma de restabelecer a ordem expressiva e as faces apoiadas por esta ordem); agradecimento (a pessoa perdoada transmite um sinal de gratidão àqueles que lhe perdoaram).

Para não se tornarem vulneráreis a críticas e opiniões contrárias, os participantes de uma interação verbal utilizam procedimentos atenuadores do grau de ameaça à face. Rosa (1992), em seus estudos sobre marcadores de atenuação, pôde identificar duas categorias: uma que promove o apagamento das marcas da enunciação, denominada "marcadores de distanciamento"; outra que, ao contrário da primeira, manifesta as marcas da enunciação no enunciado, chamada de "marcas da enunciação".

Entre as marcas da enunciação que auxiliam na preservação da face, numa interação verbal, Rosa (1992) aponta quatro tipos nessa categoria:

a- Marcadores de opinião: podem indicar um grau de incerteza e/ou orientar a interpretação do enunciado para determinado enquadre. Seu emprego tem por finalidade, também, afastar atos ameaçadores à face do interlocutor. Alguns exemplos: "eu acho que", "eu creio que", "eu suponho que", "eu acredito que", "me parece que", "eu vejo", "eu considero", “eu entendo que", "pessoalmente", "na minha opinião".

19 Os atos colocados em movimento para restabelecer esse equilíbrio são chamados "intercâmbio". 
No exemplo a seguir (E), retirado do corpus da pesquisa, o entrevistador (L13) solicita ao entrevistado (L2) sua opinião "você não acha" (linha 364) a respeito da edição do debate entre Lula e Collor, realizada pela Rede Globo e veiculada no Jornal Nacional. Segundo o enunciado de L13, essa edição teria ajudado o entrevistado, L2, a vencer as eleições de 1989 (linhas 367 a 371).

\section{(Exemplo E)}

L13 já que tava falando de manipulação... eu queria saber se... você não acha que se não tivesse sido tão ajudado pela Rede Globo... principalmente no seu último debate com o Lula que foi editado para ser passado no Jornal Nacional se o senhor teria ganhado as eleições? ((gritos e aplausos do auditório))

transmissão é ao vivo... que manipulação pode haver?... nenhuma manipulação eu acredito que o o::: o fundamentalmente o que::: o que houve... o que houve... o que houve do mesmo modo que no primeiro debate eu não fui bem... no segundo debate eu acho que fui melhor que o Lula... então o que ficou foi a impressão do último debate

Como pudemos constatar, na resposta do entrevistado L2 (exemplo E, linhas 405 a 413), apesar de indicar um grau de incerteza, os marcadores não constituem, no momento, uma expressão de dúvida. Assim, encontramos dois marcadores de opinião, em que o locutor orienta seu interlocutor sobre como interpretar o enunciado em desenvolvimento, criando um novo enquadre totalmente diferente do enquadre proposto pelo entrevistador L13.

b- Marcadores prefaciadores metadiscursivos ${ }^{20}$ : antecipam de maneira explícita a função ilocutória da intervenção que introduzem, minimizando os efeitos de uma possível ameaça à face dos interlocutores e à própria face do locutor. São exemplos "antes disso eu quero dizer

20 No próximo capítulo, abordaremos a metadiscursividade como recurso-textual-interativo que colabora com o funcionamento das estratégias interacionais de preservação da face e das estratégias argumentativas. 
uma coisa", "e diria mais", "eu gostaria de acrescentar o seguinte".

Vejamos, no próximo exemplo (linhas 421 a 423), o marcador prefaciador com a função de anunciar o que será dito a seguir, atenuando a ameaça à face do interlocutor. Trata-se de "primeiro eu queria dizer que" e "e depois eu queria saber que", marcadores metadiscursivos que explicitam a elocução que virá a seguir.

\section{(Exemplo M)}

L14 primeiro eu queria dizer que eu tenho esperança de que você não vá para o segundo turno... e depois eu queria saber que::: você gostando tanto da natureza por que o senhor não fez nada pelo meio ambiente

No exemplo M, é notável também a quebra de expectativas provocada pelo locutor, pois, numa entrevista televisiva, pressupomos perguntas realizadas pelo entrevistado e não comentários a respeito do que ele deseja ou não ao entrevistado. Assim, o locutor, sabendo do rompimento do contrato estabelecido nesse tipo de interação, ameniza a ameaça a sua própria face.

c- Marcadores de rejeição: procuram controlar, antecipadamente, possíveis reações desfavoráveis ao que é enunciado. Possui a função de preservar a face do interlocutor restringindo a possibilidade de respostas desfavoráveis e interpretações danosas à interação. Alguns exemplos: "não sei se...mas", "que eu me lembre", "que eu saiba", "se não estou enganado", “o que eu me lembro é que”.

No exemplo a seguir (linhas 445 e 451), o interlocutor elimina uma possível reação desfavorável de seu interlocutor, indicando uma incerteza - "não sei se (...) mas" - quanto ao fato de seus interlocutores não se lembrarem do que ocorreu com os iannomanis. 
(Exemplo N)

445

(...) na questão indígena... não sei se vocês se lembram... mas nós conseguimos salvar os ianomani...os iannomani estavam sendo dizimados pela ação... dos homens brancos... e por ação de uma poLítica indigienista que o/os levaria certamente à extinção... e nós fizemos uma reserva de oito:: milhões de hectares na Amazônia... exatamente para preservar uma das culturas mais antigas de que se tem notícia nas nossas Américas... (...)

Desta maneira, através do marcador de rejeição, o locutor proteje sua face, possibilitando uma saída caso obtenha uma resposta desfavorável de seu interlocutor.

d- Os marcadores hedges: alteram o valor ilocutório do enunciado. Alguns podem sinalizar uma atividade de planejamento verbal (hedges indicadores de atividades cognitivas) e outros podem diminuir o comprometimento do locutor com seu enunciado (hedges que expressam incerteza). Porém, há ocorrência de marcadores hedges que compartilham tanto das características dos hedges "indicadores de atividades cognitivas" quanto dos hedges "que expressam incerteza”. Segundo Galembeck (1999: 188):

Os marcadores "hedges" de ambos os tipos funcionam como elementos de atenuação do valor ilocutório dos enunciados, pois provocam no ouvinte um efeito de dúvida, imprecisão ou incerteza e, assim diminuem a "responsabilidade" do locutor com relação aos conceitos emitidos. Por isso mesmo, esses marcadores cumprem um papel análogo ao que é exercido pelos marcadores de rejeição, e previnem eventuais reações desfavoráveis, preservando, assim, a face do falante.

São exemplos de marcadore hedges indicadores de atividades cognitivas - "assim", “quer dizer”, “vamos dizer”, “digamos”, “digamos assim”, “sei lá”, “não sei” - e marcadores hedges indicadores de incerteza - "talvez", "quem sabe", “às vezes", "provavelmente", 
"normalmente", "de certa forma".

Localizamos às linhas 112 a 116, o marcador hedge "assim" que preenche uma pausa de planejamento verbal e modifica a força da asserção, atenuando uma possível imposição que delas pudesse decorrer.

(Exemplo O)

L2 em nenhum instante não me foi dado ah: oportunidade de poder falar... dentro ((risada)) dentro do processo... de modo que as coisas foram acontecendo assim de uma forma ah:... violenta... e ah: ah ah inclusive... afetando a própria constituição né?... de modo que:: o que eu desejo nesse momento é de colocar o meu nome ao julgamento popular é só isso

Ao ser questionado sobre as ações de seu governo para preservar a natureza, Collor, após enumerar o que foi realizado durante seu mandato em prol dessa natureza, faz uma digressão em que nos informa sobre seu gosto por esportes velozes, como o jet ski, conforme constatamos a seguir (linhas 456 a 459):

\section{(Exemplo P)}

L2 eu gostava muito e continuo gostando hoje talvez um pouco menos mas eu gosto de velocidade eu gosto de esportes perigosos... e eu fazia... eu fazia jet ski...

Conforme pudemos constatar, no exemplo anterior (P), o marcador hedge "talvez" indica um grau de incerteza e diminui o comprometimento do locutor com seu enunciado. Esses marcadores podem ser considerados atenuações, porque modalizam o grau de adesão do locutor, em relação ao seu enunciado, e indicam uma atitude pouco precisa. Dessa forma, auxiliam na preservação da face do locutor. 
A escolha de um marcador de atenuação depende do grau de informalidade existente entre os interlocutores, das próprias condições contextuais do evento interacional em andamento e da negociação da identidade social (face) que se quer exibir ou preservar (Rosa, 1992:93). Esses marcadores de atenuação constituem importantes recursos lingüísticos de preservação da face utilizados, estrategicamente, no controle da interação face-a-face, uma vez que interferem na reação verbal do interlocutor, disponibilizando ao locutor, uma alternativa para proteger sua face, caso ocorra uma reação desfavorável.

Sendo assim, com o intuito de estudarmos as estratégias de preservação da face, a interação verbal será considerada uma atividade cooperativa, em que interlocutores preocupam-se em manter uma imagem pública compatível com a linha adotada por eles. Para isso, utilizam procedimentos para preservarem imagens públicas utilizados num jogo em que o locutor, ao proteger a sua imagem, pode ocasionar uma ameaça à face do interlocutor e, conseqüentemente, uma ameaça a sua própria face.

Em nossos estudos, até o momento, discorremos sobre determinados aspectos das estratégias interativas. Porém, durante uma interação verbal, utilizamos também estratégias argumentativas, as quais nos auxiliam na tentativa de mudar o comportamento de nosso interlocutor. A seguir, destacaremos algumas características das estratégias argumentativas que, juntamente com as interacionais, contribuem com o objetivo de reconstrução da imagem pública, em uma entrevista televisiva.

\subsection{Estratégias argumentativas}


As estratégias argumentativas possuem como finalidade o aumento da eficácia do discurso, de acordo com os objetivos pretendidos pelo locutor. A eficiência dessas estratégias depende do conhecimento sobre os interlocutores a quem a fala é dirigida. Elas procuram causar influência sobre o sistema de conhecimentos enciclopédicos ocasionando, dessa forma, uma mudança no comportamento do interlocutor, ou seja, procura levar o interlocutor a efetuar uma ação pretendida ou a ter vontade para realizar uma ação desejada pelo locutor.

A importância da adesão dos interlocutores (auditório) para a eficácia de uma argumentação é abordada pelos trabalhos de Perelman e Olbrechts-Tyteca (2002), autores que promoveram um estudo sobre as técnicas de argumentação, a partir de uma reflexão crítica e atualizada dos princípios da Retórica Aristotélica aplicados em nossa contemporaneidade.

Conforme esses autores, para obter a adesão de seu público, o locutor precisa conhecer, previamente, valores sociais e culturais de seu interlocutor (auditório). Assim sendo, a imagem inadequada do interlocutor (auditório) pode levar a conseqüências desagradáveis, como a transformação de um argumento utilizado em benefício do falante em um argumento contra.

A observação dos vários papéis sociais desempenhados pelos mesmos interlocutores também pode colaborar para a escolha de argumentos eficazes, pois os argumentos utilizados para um público podem não ter o mesmo efeito quando utilizados com outros públicos.

Para iniciar uma argumentação é necessária uma pré-disposição dos interlocutores para determinarem um acordo: "Em nosso mundo hierarquizado, ordenado, existem geralmente regras que estabelecem como a conversa pode iniciar-se, um acordo prévio resultante das próprias normas da vida social” (Perelman e Olbrechts-Tyteca, 2002:17). Esse acordo estará presente tanto no início quanto no desenvolvimento da argumentação e estará ligado ao que é presumidamente admitido pelos ouvintes, ou seja, o orador precisa ter em 
mente um auditório que partilhe dos mesmos valores.

Para o acordo efetuar-se, o auditório deverá aderir às verdades, aos fatos $\mathrm{e}$ às presunções. Caso um fato ou uma verdade seja questionado pelos interlocutores, o enunciado poderá perder seu estatuto privilegiado.

Sobre manifestações de acordo e desacordo, Aquino (2005:177) afirma:

Sabe-se que há a possibilidade de se chegar a acordos parciais em que o interlocutor modifica de algum modo sua posição, porém não a muda totalmente. A negociação parece apresentar dimensões segundo a competência dos participantes e o enquadre que se apresente.

Dessa forma, toda argumentação pressupõe um acordo entre orador e auditório, sobre um determinado número de dados, entre os quais se destacam fatos, hierarquias, verdades, estruturas do real, presunções ou valores, enfim, um conjunto de crenças comuns denominado lugares (no sentido de lugar-comum) e que permitem argumentar com melhor eficácia ou não (Perelman e Olbrechts-Tyteca, 2002).

Para o estudo da argumentação, é necessário considerar a escolha de dados e também a interpretação atribuída a eles: "O estudo da argumentação nos obriga, de fato, a levar em conta não só a seleção de dados, mas igualmente o modo como são interpretados, o significado que se escolheu atribuir-lhes" (op. cit:137.). Os autores também mencionam que o discurso persuasivo só tem sentido quando inserido em uma situação, ou seja, o significado de um argumento isolado, fora de um contexto, pode ter valores ambíguos.

Para explicar as técnicas argumentativas, Perelman e Olbrechts-Tyteca (op. cit.) definem dois importantes processos: de ligação e de dissociação. Porém, apesar de separar em sua análise dois grupos de processos argumentativos, eles sugerem que não devemos 
considerá-los entidades isoladas, pois alguns argumentos podem pertencer tanto a um quanto a outro grupo.

Assim, um mesmo argumento pode constituir de um ponto de vista uma ligação e de outro ponto de vista, uma dissociação. As duas técnicas são complementares e operam juntas, porém o locutor poderá escolher aquela que é mais adequada aos seus objetivos.

Os processos de ligação propõem a aproximação de elementos distintos estabelecendo uma relação de solidariedade. Os processos de dissociação, pelo contrário, tem por objetivo separar, dissociar elementos dentro de um conjunto. "A dissociação terá o efeito de modificar tal sistema ao modificar algumas das noções que constituem suas peças mestras" (Perelman e Olbrechts-Tyteca, 2002:215).

Entre os esquemas de ligação, os autores apresentam os argumentos quase-lógicos e os argumentos baseados na estrutura do real. Os argumentos quase-lógicos são aqueles que "pretendem certa força de convicção, na medida em que se apresentam como comparáveis a raciocínios formais, lógicos ou matemáticos” (2002:219). São analisados os que apelam para estruturas lógicas (contradição, identidade total ou parcial, transitividade) e os que apelam para relações matemáticas (relação da parte com o todo, do menor com o maior, relação de freqüência).

Os argumentos baseados na estrutura do real "valem-se dela para estabelecer uma solidariedade entre juízos admitidos e outros que se procura promover" (2002:297). São analisados argumentos que se aplicam a ligações de sucessão, que unem um fenômeno a suas conseqüências ou a suas causas; e argumentos que se aplicam a ligações de coexistência, que unem uma pessoa a seus atos, um grupo aos indivíduos que dele fazem parte e de uma forma geral uma essência a suas manifestações, como, por exemplo, o argumento de autoridade. 
Perelman e Olbrechts-Tyteca (2002) também destacam o emprego das figuras de retórica como fatores de persuasão, ou seja, figuras que possuem função argumentativa, se consideradas não só como um modo literário de expressão, mas, principalmente, como técnica do discursivo persuasivo. Essas figuras possuem modos de expressão que não se enquadram no uso comum e, por isso, atraem a atenção do interlocutor.

Entretanto, as figuras de retórica só assumem seu significado argumentativo quando seu uso, embora incomum, parece adequado em um determinado discurso. "Consideraremos uma figura argumentativa se, acarretando uma mudança de perspectiva, seu emprego parece normal em relação à nova situação sugerida" (op. cit: 192). Assim, para ser reconhecida como uma figura de retórica ou não, é preciso notar, além de seu uso incomum, o discurso em que está inserida e a adesão do interlocutor à argumentação sugerida por ela.

Para classificá-las, Perelman considera a finalidade a que se destinam na argumentação: impor ou sugerir uma escolha - figura de escolha; tornar presente o objeto do discurso na consciência do interlocutor - figura de presença; buscar a comunhão com o auditório - figura de comunhão.

Em outro estudo realizado por Aquino (1997:205) sobre as ocorrências das estratégias discursivas em interações polêmicas, é proposta uma divisão entre as estratégias que podem fortalecer o locutor e aquelas que podem enfraquecê-lo, em um contexto determinado. Para a autora, são consideradas estratégias que fortalecem o locutor: antecipar objeções, recordar; recordar ao interlocutor um conhecimento que este não tem ou uma ocorrência que não houve, deixando-o, às vezes, em dúvida; apelar à razão; refutar; formular concessão; entrar em desacordo com o ato enunciativo; atacar a imagem do interlocutor; apelar para as emoções; apelar para certas habilidades/atitudes, como o uso da ironia (embora inversamente se empregada em demasia), da repetição, da correção; promover a relação de inclusão; estabelecer relação de comparação ou de analogia; proceder à relação de causa e efeito; 
observar a relação de coexistência; imprimir a relação de direcionalidade; utilizar argumento de autoridade; utilizar argumento baseado em dados documentados fidedignos; formular pergunta retórica; elaborar pergunta assimilável à negação.

Dentre aquelas que podem enfraquecer o locutor, a autora aponta as seguintes: evitar (mudando-o) ou retardar o desenvolvimento do tópico; desprezar o debate; proceder a invalidação do que foi enunciado; fazer uso da retificação; impor um acordo; utilizar dados documentados não fidedignos.

Conforme já fora explicitado anteriormente, a argumentação de um locutor (orador) fundamenta-se numa representação de seus interlocutores (auditório). Deste modo, o locutor constrói sua imagem a partir da imagem que ele faz de seus interlocutores, pois, numa interação verbal, os participantes possuem informações iniciais uns dos outros que promovem a definição da situação e o planejamento de como agir para obterem a resposta desejada, em relação as suas expectativas. Essas informações iniciais compõem uma imagem prévia, que será relacionada, a seguir, com argumentos que unem uma pessoa a seu ato (ligações de coexistência).

\subsubsection{Relações entre o locutor e seus atos}

Segundo Perelman e Olbrechts-Tyteca (2002), existe uma solidariedade entre a construção da pessoa e o conjunto de atos praticados por um indivíduo, o que possibilita atribuir à idéia de pessoa uma impressão de estabilidade, pois o locutor pode ser reconhecido através de seus atos.

Mondada \& Dubois (2003) afirmam que os processos de estabilização das categorias 
evoluem de um nível psicológico, através dos protótipos, a um nível lingüístico, em que encontramos os estereótipos. Para as autoras, os protótipos seriam construções psicológicas e individuais que, ao serem compartilhadas entre muitas pessoas através da comunicação lingüística, transformam-se em um “objeto socialmente distribuído" e estabilizado denominado estereótipo.

Entretanto, ao discutirmos a estabilidade atribuída a uma pessoa, precisamos considerá-la relativa, porque se opõe à possibilidade de mudança de um interactante, o que permite deduzir que o locutor e o ato possuem uma ligação e uma independência relativa.

Assim, essa estabilidade relativa auxilia-nos na constatação de que a imagem de um interactante está em constante construção, pois a nossa concepção a respeito do locutor pode mudar de acordo com os atos novos ou antigos que lhes são atribuídos: o ato pode nos obrigar a reconstruir uma concepção de pessoa, a classificá-la numa categoria diferente daquela classificada anteriormente (Perelman e Olbrechts-Tyteca, 2004:227).

A disposição para aceitar o que se diz antes mesmo de ter sido dito está ligada à imagem do locutor, ou seja, suas declarações podem confirmar ou não características que lhes são atribuídas antes de tomar a palavra. É possível observar a influência do locutor no momento em que suas afirmações são aceitas pelos interlocutores: "quando o que é dito sai da boca de um autor cuja autoridade é reconhecida, esta autoridade transmite-se à coisa dita, que tende a ser ainda melhor aceite" (Olerón, 1983:101).

O locutor, reconhecido por sua autoridade, possui prestígio perante a sociedade e desperta em seus interlocutores a vontade de imitá-lo (Olerón, 1983:100). Porém, esse prestígio pode crescer ou decrescer de acordo com os efeitos da argumentação.

Um argumento de prestígio característico é o argumento de autoridade, em que atos ou juízos de uma pessoa ou de um grupo são utilizados a favor da argumentação realizada pelo locutor. Esse argumento é fundamentado com maior freqüência na competência do locutor, 
pois aquele que tem conhecimento do assunto explanado, com mais facilidade poderá construir uma argumentação eficiente e obter, por parte de seus interlocutores, o prestígio esperado.

Contudo, a competência não basta se o público suspeitar que o locutor procura influenciar seus interlocutores segundo suas posições ideológicas. A sinceridade demonstrada pelo locutor ao apresentar a informação de uma maneira não dissimulada e sua competência determinam a credibilidade de seu discurso. "Com efeito, o orador deve inspirar confiança; sem ela, seu discurso não merece crédito.” (Olerón, 1983:362).

Essas observações a respeito das relações existentes entre o locutor e seus atos nos permitem entender que, ao considerar determinados valores e crenças atribuídas ao seu público, o locutor precisa se adaptar ao auditório e construir uma imagem confiável de sua pessoa. Assim, ele pode modelar sua imagem transmitida de acordo com as representações coletivas as quais assumem um valor positivo.

Ao tratarmos, neste capítulo, sobre alguns princípios que envolvem as estratégias interacionais e argumentativas em interações verbais, tivemos por proposta entender o funcionamento de estratégias discursivas que colaboram para a manutenção, construção ou reconstrução da imagem. Entretanto, dispomos de outros recursos lingüísticos para alcançarmos nossos objetivos durante uma interação, como a questão da metadiscursividade. Trata-se de um recurso textual-interativo, que apresenta suas relações com a mudança de footing e, por isso, interessa-nos.

3.3. A metadiscursividade como recurso textual-interativo 
O metadiscurso caracteriza-se por ser um discurso que se torna evento e objeto de menção, fazendo referência ao próprio processo discursivo. Assim, ele constitui uma propriedade auto-reflexiva da linguagem, ou seja, ele promove uma integração entre enunciado e enunciação.

Ao mesmo tempo em que produz o próprio discurso, resultado da interação verbal entre interlocutores, realiza também uma menção à atividade lingüístico-textual-interativa, designando-a e qualificando-a numa referência interna ao "fazer" discursivo. (Risso, 2000: 104). Segundo a autora:

$\mathrm{Na}$ sua condição de discurso auto-referente, pela tomada de elementos discursivos como objeto de enfoque, o metadiscurso entra, na composição do texto, em pauta diferenciada da estrutura essencialmente informacional dos tópicos: como manifestação explícita de controle do uso da linguagem, projeta, no produto verbal, a instância produtora e o desenvolvimento emergencial do processamento formulativo, em situação comunicativa concreta.

Por serem estabelecidos na integração entre o enunciado e enunciação, os enunciados metadiscursivos operam no âmbito da atividade enunciativa, em que evidenciam momentos de processamento verbal na interação, estabelecem-se como elementos de antecipação, avaliação e comentários da produção discursiva (Risso e Jubran, 1998).

Tomando por base o trabalho desenvolvido pelas autoras, apontamos para algumas características e funções atribuídas aos enunciados metadiscursivos:

a- controla o comportamento verbal do interlocutor

b- aponta para as instâncias produtoras do discurso

c- controla a atividade discursiva, suspendendo temporariamente o fluxo informacional

d- atua como procedimentos típicos de qualificação, envolvendo avaliações e comentários 
e- explicita uma direção argumentativa

f- auxilia na preservação da faces

g- oferece pistas para a identificação e caracterização do papel discursivo do locutor

De acordo com os estudo de Borillo (1985), existem três modalidades de intervenção do metadiscurso: a que faz referência ao discurso para especificar aspectos do código em uso na construção do texto, a que se refere ao discurso como fato enunciativo, e a que se refere ao discurso enquanto construção de enunciados.

O metadiscurso, como recurso-textual interativo, mobiliza conhecimentos sociocognitivos e interacionais durante uma interação verbal e desenvolve várias funções de ordem cognitiva, organizacional, discursiva-argumentativa e interacional.

Geralmente, posicionam-se como prefaciadores, antecipando o valor discursivo do enunciado que introduzem e, assim como já vimos no capítulo anterior, a metadiscursividade é explicitada no texto através dos marcadores metadiscursivos que, por sua vez, podem ser utilizados para determinar um enquadre, ao indicarem aos interactantes pistas de como devem compreender o que será enunciado a seguir.

Isso nos possibilita estudar a metadiscursividade como um indicador de mudança de footing, ao considerá-la um elemento que provoca um enquadramento. De fato, quando um discurso possui em seu conteúdo referências a outro discurso, o locutor produz um novo enquadre, uma nova situação em que os participantes da interação precisam se alinhar para poderem interpretar o novo contexto, conforme passaremos a indicar.

3.4 A metadiscursividade e a mudança de footing 
Os estudos sobre as bases estruturais do footing permite-nos observar que, entre os traços lingüísticos sinalizadores de sua mudança, encontram-se os marcadores metadiscursivos.

A metadiscursividade revela-se como um recurso que pode ser utilizado, estrategicamente, para valorizar ou desvalorizar um discurso alheio, na interação entre interlocutores que possuem diferentes opiniões. Ao ser utilizado, ele marca um alinhamento do locutor de acordo com o enquadre pretendido.

Observamos, à página 59 deste trabalho, que as mudanças de footing podem ocorrer quando se altera o status participativo dos interactantes ou quando ocorrem os chamados encaixamentos (Goffman, 2002). Entendemos que a metadiscursividade, como um traço lingüístico, está associada aos encaixamentos que inserimos em nossas elocuções.

Conforme Hilgert (2006:184), "na construção do texto falado, o falante assume dupla função enunciativa: ele é aquele que enuncia e, ao mesmo tempo, mantém-se atento a seu dizer, fazendo, em diferentes pontos da evolução do discurso, observações sobre o dizer.”

Podemos, então, entender que a heterogeneidade das enunciações revela-se nas construções metadiscursivas que são utilizadas pelos interactantes, com diferentes finalidades e características. Temos, assim, um locutor que produz o enunciado e um outro que analisa, interpreta, avalia, comenta o dizer ou observa as palavras utilizadas.(op. cit:164)

Dessa forma, os encaixamentos são manifestações explícitas dessa heterogeneidade enunciativa: quando apontamos em nossa fala o discurso produzido em um outro enunciado, indicamos de quem é o discurso inserido ao projetarmos nele uma figura encaixada, "eu", ou uma terceira pessoa, "ele".

Logo, se introduzimos um discurso alheio no nosso próprio discurso, precisamos 
promover um realinhamento, um footing, em função do novo enquadre que pretendemos construir.

Nos exemplos seguintes (linhas 304 a 309), verificamos uma ocorrência de metadiscurso, em que o locutor se projeta no discurso através do pronome "eu". Temos, assim, dois interactantes envolvidos no enunciado: um animador que enuncia, responsável pelo discurso que acontece; e outro animador encaixado, ou seja, uma figura inserida num plano sobre o qual se está falando.

(Exemplo Q) 305

L11: oi eu queria saber como você responde hoje as acusações que foram feitas sobre o uso de drogas

L2: $\quad$ sobre o uso de drogas? ((aplausos e gritos do auditório)) olha ((risada)) isso aí ((risada)) isso aí já...já foi tão...tão dito e tão... e tão repetido não é? eu quero dizer a vocês que... eu quero dizer a vocês que... ah:: todas essas acusações... também são acusações falsas...

No exemplo seguinte, (linhas 459-462), o enunciador utiliza uma figura encaixada através do pronome "ele" para citar o discurso de outra pessoa.

\section{(Exemplo R)}

L2:

(...) o comandante 460 ((tossiu)) Jacques Costeau... ((tossiu)) que faleceu recentemente... no ano passado ele chegou pra mim e disse assim ((tossiu)) eu queria the fazer um pedido ((pausa prolongada)) que você parasse de andar de jet ski... (...)

Podemos perceber que, nos dois últimos exemplos ( $\mathrm{Q}$ e R) os recursos metadiscursivos possuem a função de direcionar a interpretação realizada pelo interlocutor, isto é, são utilizados com o intuito de promoverem um enquadre, conforme os objetivos dos locutores. 
No exemplo (Q), “eu quero dizer”, uma mudança de footing ocorre, para que os interlocutores se alinhem e possam compreender o enquadre proposto: as acusações são falsas. Essa mudança de footing é sinalizada pelo marcador metadiscursivo que projeta a figura de um "eu" no enunciado elaborado.

No exemplo (R), “disse assim”, o marcador metadiscursivo encaixado "ele”, também é utilizado para sinalizar uma mudança de footing, um alinhamento na posição dos interlocutores, a fim de que possam se enquadrar, conforme o enquadre proposto: o discurso a seguir não é de quem enuncia, e sim de uma figura encaixada, um outro.

Portanto, ao promoverem um novo enquadre, um footing é sinalizado através das figuras encaixadas "eu" e "ele", que constituem recursos metadiscursivos e contribuem para que os interlocutores possam se alinhar e compreender o que está sendo enunciado.

Essas expressões metadiscursivas auxiliam no desenvolvimento tanto de estratégias interacionais, ao colaborarem na preservação das faces dos interactantes, quanto de estratégias argumentativas, atuando na organização argumentativa dos enunciados.

A discussão teórica até aqui apresentada permite-nos proceder à análise do corpus, no que concerne à localização e compreensão do emprego das estratégias interacionais e argumentativas no discurso e à observação de que podem ser utilizadas para tentar promover uma mudança de opinião nos participantes de uma interação face a face. 


\section{CAPÍTULO IV}

\section{ANÁLISE DAS ESTRATÉGIAS}

\section{UTILIZADAS POR FERNANDO}

COLLOR DE MELO E POR SEUS

INTERLOCUTORES DURANTE O

"PROGRAMA LIVRE" 
Nos capítulos anteriores, procedemos à análise de alguns exemplos retirados do corpus da pesquisa, visando a uma explicação mais detalhada sobre as teorias abordadas; entretanto, ainda não observamos o funcionamento conjunto de todos os conceitos discutidos até aqui. Ou seja, entendemos que as análises efetuadas não possibilitaram uma visão de que as estratégias interativas e argumentativas operam conjuntamente e organizam-se no jogo interacional para promoverem (ou não) a (re)construção da imagem de Fernando Collor de Melo perante seus interlocutores.

Com as análises, objetivamos, pois, observar as estratégias discursivas selecionadas pelos participantes da entrevista televisiva indicada, a fim de detectar os objetivos dos interlocutores durante essa atividade discursiva.

Para atingirmos esse propósito, dividimos as análises segundo papéis sociais e discursivos negociados entre os interactantes, durante a entrevista televisiva: a apresentação de Collor e a imagem atribuída aos entrevistadores; a imagem atribuída pelos entrevistadores a Collor e o mediador no papel de entrevistador. Deste modo, destacamos segmentos da entrevista exibida pelo SBT, no Programa Livre, em agosto de 1998, em que analisamos estratégias interacionais de preservação da face e, também, estratégias argumentativas utilizadas no jogo interacional. O entrevistado, ex-presidente Fernando Collor de Melo, identificado nas análises como locutor 2 (L2), pretendia candidatar-se novamente à Presidência da República, após ter sido afastado em 1992 de seu cargo político, devido às denúncias de corrupção no governo federal, como já o dissemos. Seu auditório é composto por vários estudantes de ensino médio, alunos de escolas indicadas como Equipe, Bandeirantes, Logus,. Arquidiocesano, Argos de Santo André e Anglo Vestibulares.

Não conhecemos o número exato de participantes-entrevistadores, mas temos o registro de 15 jovens que fazem as perguntas. Eles são identificados em nossas análises como locutores (L) e numerados de 3 a 17 (L3, L4, L5, L6, L7, L8, L9, L10, L11, L12, L13, L14, 
L15, L16 e L17). O mediador, Sérgio Groisman, é identificado como locutor 1 (L1). Em razão de a entrevista ter sido transmitida ao vivo, em canal aberto, há também a existência de um auditório universal composto pelos telespectadores.

A duração do Programa foi de uma hora. Procedemos à gravação (Anexo 2) e à transcrição (Anexo 1) de acordo com as normas do Projeto Nurc-SP (indicadas na introdução deste trabalho). Nos exemplos a seguir, sublinhamos as palavras ou expressões que merecem destaque nas análises.

4.1 A apresentação de Collor e a imagem atribuída aos entrevistadores

4.1.1 A influência do contexto na reconstrução da imagem

O entrevistado representa uma identidade social capaz de definir alguns aspectos da entrevista; assim, no caso de um político, espera-se um programa televisivo que informe sobre o envolvimento do entrevistado com a política (Charaudeau, 2006). Em nossa pesquisa, ao analisarmos a imagem social de um entrevistado como Collor, ex-presidente acusado de corrupção e afastado da Presidência da República por um impeachment, ou seja, marcado por atos praticados em seu passado, a expectativa é de que a entrevista forneça informações sobre sua relação com os escândalos políticos, suas justificativas e seus planos futuros. Foi o que observamos em algumas perguntas realizadas pelos entrevistadores (linhas 34 a 37; 58 a 60; 151 a $154 ; 259$ a $262 ; 367$ a $371 ; 669$ a 671$):$ 


\section{(Exemplo 1)}

L3: Rodrigo do Colégio Arbes... o senhor acredita que foi julgado e condenado por que estava num partido de menor poder político? assim... se o Sr. estivesse num PMDB ou num PFL se não... não seria condenado... no impeachment?

L4: é::... diante de uma possível candidatura nessas eleições... como o senhor pretende i/éh:: se apresentar diante do povo que uma vez te elegeu e depois te depôs... e quais são as suas propostas?

L6: é...eu queria saber ...depois de... depois de tudo que o senhor foi acusado... o que você acha da miséria assim que está no Brasil... na:: em questão à seca... do nordeste assim... e o que o senhor acha do plano do Fernando Henrique?

L10: gostaria de saber a sua opinião... sobre a grave cri::se:: social que o país está enfrentando no governo Fernando Henrique... inclusive o desemprego que é assustador um milhão e seiscentos mil de desempregados só na grande São Paulo?

L13: já que tava falando de manipulação... eu queria saber se... você não acha que se não tivesse sido tão ajudado pela Rede Globo... principalmente no seu último debate com o Lula que foi editado para ser passado no Jornal Nacional se o senhor teria ganhado as eleições? ((gritos e aplausos do auditório))

L17: durante as eleições em $89 \ldots$ você falou que o Lula ia confi/ confiscar as poupanças e quem acabou fazendo isso um dia depois de ser eleito foi você... cê acha que um:: candidato POde mentir para ser eleito ou omitir?

O teor das perguntas elaboradas pelos jovens entrevistadores vai dando ciência ao expresidente de sua imagem social abalada por atos de corrupção, motivo pelo qual tenta reconstruir sua identidade social, a partir dos conhecimentos que possui sobre as características situacionais e cognitivas do contexto (Marcuschi, 1995), tais como:

a- as normas que determinam o formato do programa de entrevista televisiva, ou seja, as regras que organizam as relações entre os participantes da entrevista (entrevistado, 
entrevistador, mediador, platéia e telespectador);

b- a duração da entrevista para que possa manter por mais tempo o seu turno, como veremos pelos longos turnos que utiliza para responder as perguntas;

c- o espaço físico onde será entrevistado e o dispositivo de mídia em que será transmitida a entrevista;

d- os vários papéis (sociais e interacionais) desempenhados pelos participantes, pois através do conhecimento das crenças, valores, ideologias e atitudes que compõem a imagem social de de seus interlocutores e a noção sobre as funções de seus papéis discursivos é que escolherá as estratégias discursivas, aquelas as quais julga mais eficientes para atingir seus objetivos interacionais.

Na entrevista analisada, o apresentador do Programa Livre, Sérgio Groisman, ora desempenha o papel de mediador, ora assume o papel de entrevistador. É ele quem, no início, classifica o programa como "especialíssimo" e informa que a entrevista será dividida em dois grandes blocos, para que possam ganhar mais tempo para as perguntas - o que difere de outras entrevistas, apresentadas no programa, as quais possuem vários pequenos blocos interrompidos por anúncios publicitários, como se observa no segmento 2.

Os entrevistadores não são especialistas políticos e sim jovens adolescentes, estudantes de ensino médio e de cursinhos preparatórios para o vestibular, como podemos observar na apresentação do programa por L1 (linhas 1 a 9):

(Exemplo 2)

L1 MAIS SOM ... ((aplausos)) mais mais mais mais mais mais mais... ((aplausos)) e boa tarde garoto boa tarde garota agora mais UM::.... PROGRAMA LIVRE... Programa Livre hoje especialíssimo... vai receber o ex-presidente Fernando Collor de Melo ao VIVO... com a gente aqui... colégios Equipe.. Bandeirantes... ogus...Arquidiocesano... 
pessoal de Americana... Argos de Santo André... Anglo Vestibulares...portanto...no próximo bloco... ao vivo...o presidente expresidente Fernando Collor de:: Melo... Programa Livre dá um tempo e volta JÁ

Nesse exemplo (2), a linguagem de L1 é bem voltada à dos jovens. À linha 8 , a expressão "dá um tempo" indica-nos o caráter informal da linguagem que pode ser utilizada no programa.

Esses entrevistadores apresentados pelo mediador compõem também a platéia que, localizada no estúdio de gravação do programa, manifesta expressões favoráveis ou desfavoráveis aos enunciados elaborados. No exemplo, a seguir, podemos notar que a expressão da platéia é tão significativa (com risos, gritos e aplausos) para o entrevistado que ele procura se identificar com ela "o que eu sei que tenho é o seguinte... é o que muitos de vocês têm..." (linhas 333 e 334) e, às linhas 336 e 337, direciona seu enunciado a esses jovens, por meio de uma formulação lingüística que evidencia solicitação de apoio ou de atenção $^{21}$ dos interlocutores: "cês estão entendendo".

\section{(Exemplo 3)}

L12: é:: eu quero saber se::::assim/se:: quer se submeter a um julgamento popular agora né?... então eu quero saber se você não acha... que:: o seu poder de persuasão é maior que a capacidade de discernimento do povo... que não tem cultura... e não tem e...ducação necessária pra/e é facilmente manipulado? ((gritos e aplausos do auditório))

L2: veja que:: ((gritos do auditório)) você me atribui um poder de persuasão que eu não sei se tenho... o que eu sei que tenho

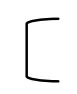

330 L(?): $\quad$ (incompreensível)

21 Embora não tenhamos tratado dos marcadores, destacamos os trabalhos de Settekorn (1977), para quem a posição dos marcadores de solicitação de apoio, se indicados no final de uma proposição, revelam intenção argumentativa e indicam busca de aprovação discursiva na interação. Veja-se, também, o trabalho de Risso, Silva e Urbano (2002). 
L2: -bom então se tenho obrigado ((risada do locutor e aplausos do auditório)) agora... agora... agora pessoal... o que eu sei que tenho é o seguinte... é o que muitos de vocês têm... eu não sei fazer nada na minha vida que não seja com

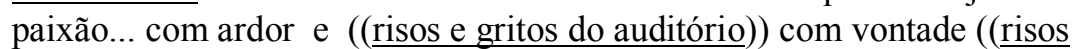
e gritos do auditório)) não não a paixão piegas ((risos)) não... não... cê̂s estão entendendo... não é essa paixão não é essa paixão piegas paixão piegas é uma paixão no sentido de me dedicar inTEgralmente àquilo que eu tô fazendo... (....)

A presença de um telespectador também é fundamental para a organização discursiva do entrevistado, pois todo seu discurso é elaborado para atingir as expectativas do público externo ao estúdio e construir ou reconstruir uma imagem social, compatível com seus objetivos (Goffman, 2002). Ao tratarmos da entrevista sob análise, torna-se significativo observar que as músicas selecionadas, a linguagem utilizada pelo mediador e a platéia formada por adolescentes atraem um público jovem que se identifica com o programa.

Assim sendo, o entrevistado precisa reconhecer características desse público jovem que teve uma importante participação na política, em 1992, quando também solicitou o afastamento do Presidente e, em anos anteriores, quando saiu marcado pela forte presença nas questões políticas do país. Desta maneira, apesar de os jovens de 1998 não serem, efetivamente, os mesmos que pediram seu impeachment em 1992, os adolescentes ainda possuem uma imagem de contestadores do sistema político vigente. Além disso, parte deles se constitui público-alvo - há muitos jovens maiores de dezesseis anos, ou seja, adolescentes que possuem o direito ao voto e que são, portanto, também eleitores.

Todos esses conhecimentos (normas interacionais, duração, espaço físico, dispositivo de mídia e papéis sociais) são acionados pelo entrevistado, por meio de esquemas e enquadres (Tannen, 1979), que colaboram para formar uma imagem a respeito de seus interlocutores e, principalmente, uma idéia da imagem que esse público jovem possui do próprio entrevistado, Collor, após todos os escândalos políticos. 
Ao tomar conhecimento desses fatores contextuais, Collor tenta modificar, através de estratégias interacionais e argumentativas, os conhecimentos sociointeracionais e enciclopédicos de seus interlocutores, a fim de reconstruir uma imagem desgastada pelo impeachment que o público ainda mantém e voltar ao cenário político através de sua candidatura, conforme veremos a seguir.

\subsubsection{A justificativa}

No exemplo (4), o entrevistador L3, Rodrigo do Colégio Arbes, ao perguntar sobre as causas que culminaram no pedido de afastamento do Presidente (linhas 34 e 37), propõe um enquadre que é reforçado (linhas 39 e 40) pelo entrevistado L2, Fernando Collor de Melo: o impeachment só ocorreu porque Collor não tinha apoio da maioria no Congresso Nacional, em razão de estar filiado a um partido menor.

\section{(Exemplo 4)}

L3 Rodrigo do Colégio Arbes... o senhor acredita que foi julgado e condenado por que estava num partido de menor poder político? assim... se o Sr. estivesse num PMDB ou num PFL se não... não seria condenado... no impeachment?

L2 não sem dúvida se eu tivesse maioria no Congresso Nacional... jamais... teria acontecido o chamado impeachment... e isso não foi dito por mim quer dizer isso foi dito pelos líderes inclusive da oposição... ah::: no fundo o que nós percebemos é que na eleição de $1989 \ldots$ ela foi uma eleição solteira... ou seja foi eleito apenas o Presidente da República não houve eleição para deputado e para senador... de modo que quando eu tomei posse em março de $90 \ldots$ o Congresso... com o qual eu comecei a governar era o Congresso eleito em $1986 \ldots$ portanto... eleito esse Congresso num moMENto diferente da minha eleição seis meses depois da minha posse... houve a renovação desse congresso... que também foi eleito num moMENto diferente... daquele que elegeu o presidente em 89 essa eleição de 98 é uma eleição diferente porque é uma eleição casada... ou seja... quando a gente vai votar no presidente que a gente quiser... a 
gente é levado a votar... nos candidatos a deputados e senador... que estejam identificados com esse presidente... e isso constitui-se então a chamada base parlamentar... eu não tinha base parlamentar... o meu partido era pequeno... e continua sendo pequeno... se eu tivesse maioria no congresso nacional... nada disso teria acontecido.

Após contribuir com o enquadre sugerido por L3, nas linhas 34 a 37, de que se estivesse num partido de maior poder político não teria sofrido impeachment, o entrevistado sinaliza uma mudança de footing (Goffman, 2002) a partir do uso do marcador discursivo “quer dizer", e sugere um novo enquadre - quem diz são os líderes da oposição e não ele, o entrevistado (linha 40).

Nesse novo enquadre, identificamos uma estratégia argumentativa em que Collor introduz um argumento de autoridade, "os líderes da oposição" (linha 40), para fortalecer sua defesa. Outra estratégia argumentativa utilizada por Collor com o intuito de modificar a opinião dos interlocutores refere-se à relação de causa-efeito: o impeachment (efeito/conseqüência) só ocorreu, segundo ele, porque não teve maioria no Congresso Nacional (causa). Desta maneira, Collor tenta transferir o juízo de valor desfavorável atribuído ao seu impeachment à causa da ação (o fato de não ter maioria no congresso), o que diminui seu comprometimento com o processo sofrido. Temos, assim, um argumento pragmático que visa transferir para a causa o valor atribuído à conseqüência, estabelecendo o que Perelman e Olbrechts-Tyteca (2002) denominam de "ligação de sucessão" (relações de causa e conseqüência).

Ainda em relação à ocorrência de estratégias argumentativas, podemos identificar uma comparação efetuada por L2, entre a eleição "solteira" de 1989 e a eleição "casada" de 1998 (linhas 40 a 55, exemplo 4), com o intuito de justificar, a seguir, que em 1989 não teve apoio de uma "base parlamentar", fato que provavelmente não aconteceria em 1998, pois a eleição para presidente ocorreria juntamente com a eleição para senadores e deputados. Sendo assim, 
o entrevistado tenta dissociar sua imagem do processo de impeachment, pois a eleição de 1998 - na qual Collor pretendia se candidatar - seria diferente daquela em que foi eleito (em 1989) e afastado dois anos depois.

Conforme Perelman e Olbrechts-Tyteca (2002), os argumentos de comparação são apresentados como constatações de um fato, mas, na realidade, constituem relações que se constroem de acordo com a pretensão do autor - por isso são chamados de argumentos quaselógicos. Diante disso, observamos que o fato da eleição de 1998 ser diferente da eleição de 1989 contribui com o propósito de dissociar um novo mandato presidencial de um outro processo de impeachment.

Após todas essas estratégias argumentativas utilizadas por Collor em seu discurso, verificamos, no final de seu enunciado (exemplo 4, linhas 54 e 55), uma retomada do enquadre inicial, em que se registra a tentativa de eximir-se de culpa: "se tivesse maioria no Congresso Nacional o impeachment não teria acontecido".

\subsubsection{A apresentação}

(Exemplo 5)

L4 é::... diante de uma possível candidatura nessas eleições... como o senhor pretende i/éh:: se apresentar diante do povo que uma vez te elegeu e 60 depois te depôs... e quais são as suas propostas?

No exemplo 5 (linhas 58 a 60), para preservar sua face (Goffman, 1974), o entrevistador (L4), ao formular sua pergunta, conduz seu interlocutor a observar a questão 
proposta como uma possibilidade e não uma certeza sobre a candidatura de Collor (grifo linha 58). Assim, L4 evita uma posterior ameaça a sua face, caso ocorresse de o entrevistado não ter por finalidade candidatar-se às eleições daquele ano.

Após proteger sua face, o entrevistador ameaça a face positiva (necessidade de ser reconhecido socialmente) e negativa (invasão do território pessoal) de seu interlocutor, ao solicitar-lhe a apresentação de propostas para um futuro governo, na condição de um candidato que manifestou credibilidade para ser eleito e não conseguiu mantê-la, sendo deposto antes de cumprir seu mandato (linhas 59 e 60). Observe-se que o próprio ato de tentar candidatar-se novamente constitui um grau de ameaça à face de todos os brasileiros que o elegeram, e ainda concordaram com a saída de Collor da Presidência, em 1992.

Observamos também que L4 ameaça a face do entrevistado ao utilizar um argumento de reciprocidade, em que estabelece uma relação simétrica: o povo que o elegeu é o mesmo povo que o depôs. Esses argumentos de reciprocidade assimilam situações ao considerá-las simétricas, ou seja, a ordem do antecedente e do conseqüente pode, pois, ser invertida, conforme nos indicam Perelman e Olbrechts-Tyteca (2002:250).

O entrevistado (L2), ao responder a pergunta (exemplo 6), procura construir uma imagem a partir da pressuposição do valor atribuído pelos entrevistadores aos seus atos no passado:

(Exemplo 6)

L2: veja que... eu me apresento hoje diante...diante de todos vocês... tendo sido... o homem público... mais investigado desse país... o mais humilhado o mais xingado o mais achincalhado o mais execrado... $\mathrm{e}$ seguramente o mais investigado... o último homem público que sofreu alguma coisa parecida... em termos de:: de:..... investigação... foi o doutor Getúlio Vargas... em 1950... e que lamentavelmente não suporTOU... aquela pressão e deu fim a sua própria vida... então hoje eu me apresento... tendo sido... como disse... investigado de cima a baixo... quer dizer foram 2 anos de/e meio de investigação... em que investigaram... 
TOda a minha vida... e todo o resultado dessa investigação foi levado a consideração da mais alta corte de justiça do país... que me considerou inocente daquelas acusações... e eu me pergunto se hoje... há um homem... bom se nós se nós estamos vivendo num estado democrático de direito... e se nós acreditamos... que à justiça cabe julgar as denúncias 75 que são feitas... e não ao... ao nosso interesse partidário... então nós temos que reconhecer que esse é o canal legítimo... que nós podemos recorrer dentro de uma democracia... para sabermos quem está com a razão... e a mais alta corte de justiça do país... me declarou inoCENte dessas acusações eu não sei se houve um homem público brasileiro... hoje... submetido às mesmas investigações a que eu fui submetido... se eles poderiam apresentar ao final dessas investigações... esse atestado... que me foi dado pela mais alta corte de jusTIça do país... de inoCENte daquelas acusações... fui julgado pelos políticos... fui e fui condenado... fui julgado pela justiça e fui absolvido... e o que eu desejo agora... é nada mais nada menos... que seja dado o diREIto ao eleitor de fazer esse julgamento... sem intermediários... que votem contra mim ou a favor de mim... mas o eleitor... representando a sua consciência representando o seu desejo representando as suas expectativas... e não que... meia dúzia de gatos pingados... lá no Congresso Nacional... se arvorem no direito de em nome de 35 milhões de eleitores... de fazerem o que fizeram... vocês todos se lembram que quem comandou... esse processo contra mim... foi o então presidente da câmara dos deputados... chamado Ibsen Pinheiro... que três ou quatro meses após aH é:: eles terem me arrancado da presidência... eles mostraram a sua verdadeira face... Eles... os anões do orçamento... eles sim... estavam assaltando o tesouro nacional... eles sim... estavam fazendo as ...é as diabruras e travessuras que todos nós conhecemos... e se eles me arrancaram da presidência... é porque minha gente... seguramente eu não era um deles... e não estava fazendo o jogo $\underline{\text { deles }}$

O exemplo anterior, embora longo, foi necessário para indicarmos várias estratégias discursivas (interacionais e argumentativas) que são retomadas em vários momentos do enunciado de L2, na tentativa de reconstrução de sua imagem.

No exemplo 6 (linhas 61 e 99), figuras de presença - a repetição e a sinonímia intensificam a imagem de sofrimento construída por L2 em seu discurso. Dessa maneira, a repetição da palavra "mais" e a enumeração (sinonímia) de ações que possuem valor negativo em nossa sociedade - "humilhado", "xingado", achincalhado", "execrado" (linhas 62 e 63) constituem figuras que assumem seu significado argumentativo ao tornarem presente na consciência o objeto do discurso - a humilhação de Collor (Perelman e Olbrechts-Tyteca, 2002).

A seguir, o entrevistado compara, numa relação de igualdade, as investigações 
ocorridas durante o processo de impeachment com as investigações que envolveram Getúlio Vargas e associa sua imagem à coragem de ter suportado tais humilhações durante uma investigação que, outras pessoas, como Getúlio Vargas, não suportariam.

Às linhas 73 a 76, Collor emprega um argumento de direção através de uma "técnica de etapas": nós vivemos num estado democrático de direito (A), acreditamos que à justiça cabe julgar as denúncias (B) e reconhecemos que a eleição é um canal legítimo para sabermos quem está com a razão (C). Deste modo, conforme nos orientam Perelman e Olbrechts-Tyteca (2002), ao passarmos de um ponto A a C, podemos encontrar dificuldades, entretanto, é possível não haver inconvenientes se passarmos de um ponto $\mathrm{A}$ a $\mathrm{B}$, de onde o ponto $\mathrm{C}$ aparecerá sob uma nova perspectiva. Isso nos permite observar que o entrevistado utiliza o ponto $\mathrm{B}$ para reforçar o ponto $\mathrm{C}$ e conseguir, assim, o apoio dos interlocutores a sua candidatura.

Ao repetir, por três vezes, que foi inocentado (linhas 71, 78 e 82), o entrevistado reforça um argumento de autoridade (Perelman e Olbrechts-Tyteca, 2002), utilizado para transmitir ao seu discurso legitimidade e confiabilidade: foi julgado e absolvido pela justiça, aquela reconhecida por todos como capaz de julgar alguém; esse é o lugar-comum encontrado pelo entrevistador.

Assim, se pessoas que não possuem vínculos com essa justiça, ou seja, aqueles que não são juízes e não trabalham no judiciário, praticarem a ação de condená-lo, elas colocarão em dúvida toda a autoridade, competência e prestígio atribuídos pela sociedade ao poder judiciário. Ao organizar, desse modo, seu discurso, L2 cria uma potencial ameaça às faces, positiva (referente ao reconhecimento social) e negativa (território pessoal relacionado ao conhecimento), daqueles que o condenam (linhas 75 a 76).

Nas linhas 85 e 86 (exemplo 6), Collor emprega um argumento de sacrifício “que seja dado o diREIto ao eleitor de fazer esse julgamento", ou seja, ele transforma sua candidatura 
em um "direito" do público, por quem aceita ser julgado. Ao utilizar esse argumento, ele também provoca uma aproximação dos valores de seu público - o acesso ao direito e o exercício da democracia.

Ainda no exemplo 6, linhas 91 a 99, o entrevistado atribui a causa de seu impeachment ao presidente da Câmara dos Deputados, Ibsen Pinheiro, e aos "anões do orçamento". Conforme Perelman e Olbrechts-Tyteca (2002:303), "quem é acusado de ter cometido uma má ação pode esforçar-se em romper o vínculo causal e por lançar a culpabilidade em outra pessoa ou nas circunstâncias". Sendo assim, observamos que Collor transfere o valor negativo atribuído ao seu impeachment à ação dos integrantes da Câmara dos Deputados, lançando um argumento pragmático ao qual atribui a terceiros a causa de seu impeachment "eles sim... estavam assaltando o tesouro nacional... eles sim... estavam fazendo as... é as diabruras e travessuras que todos nós conhecemos...." (linhas 95 e 96). Em seguida, o entrevistado Collor, através de uma "técnica de ruptura" de interação entre indivíduo e grupo (op. cit.:369), desvincula-se da imagem negativa atribuída a esses membros da Câmara dos Deputados: "se eles me arrancaram da presidência... é porque minha gente... seguramente eu não era um deles... e não estava fazendo o jogo deles" (linhas 96 a 99).

Segundo Perelman e Olbrechts-Tyteca (2002), existem técnicas (de ruptura) que rompem ou refreiam a interação entre o locutor e o grupo quando existe uma incompatibilidade entre os dois. Assim, a única técnica que permite realizar uma ruptura entre o locutor e um grupo é o da exclusão, que pode ser feita pelo próprio locutor, pelos membros do grupo ou por terceiros.

Constatamos, desta maneira, que o entrevistado dispõe de figuras de presença (repetição e sinonímia), de variados argumentos (de comparação, de direção, de autoridade, de sacrifício e argumento pragmático) e de uma técnica de ruptura entre ele e os membros da Câmara dos Deputados para construir, em seu enunciado, uma defesa pessoal às críticas as 
quais foi submetido, por conta de seus atos (linhas 61 a 99).

Podemos observar, também, que após ter empregado todas essas técnicas argumentativas para reconstruir sua imagem (exemplo 6), Collor não responde totalmente à pergunta de L4 (exemplo 5), pois não abrange a parte das "propostas", o que corresponde à fuga quanto ao que o tópico sugeria (Aquino, 1997).

Ainda no mesmo segmento (linhas 88 a 90, exemplo 6), o entrevistado atribui o fato de ter sido deposto à responsabilidade de terceiros "meia dúzia de gatos pingados... lá no Congresso Nacional" (linhas 88 a 89), numa tentativa de minimizar os efeitos da ameaça feita à sua face. Porém, ao defender sua face, L2 ameaça a face positiva daqueles que faziam parte do Congresso e, conseqüentemente, ameaça também as faces positiva e negativa daqueles que votaram nos integrantes desse congresso.

Constatada a ameaça, o interlocutor L1 (Sérgio Groisman), no exemplo seguinte (7), elabora sua pergunta (linhas 100 a 103):

(Exemplo 7)

100 L1: agora....é ...quando quando ((aplausos)) quando o senhor fala ((pausa prolongada)) quando o senhor fala quatro ou cinco gatos pingados... o senhor tá se referindo a maioria do Congresso naquele momento... TAMBÉM eleito pelo povo assim como o senhor?

L2: sem dúvida sem dúvida/me refiro/quer dizer é uma força de expressão... eu me refiro ah:: ao Congresso Nacional comandado... por este que eu já falei o nome... e que em nome de 35 milhões... né?... tomaram aquela atitude sem terem autoridade moral para isso porque ele que comandou tudo ele que atropelou todo o processo... porque minha gente vocês talvez não tenham... parado um pouco pra acompanhar todo esse

110 processo foi uma... foi uma... do ponto de vista jurídico né?... foi uma violência atrás de outra porque não me foi dado direito de defesa em nenhum instante não me foi dado ah: oportunidade de poder falar... dentro ((risada)) dentro do processo... de modo que as coisas foram acontecendo assim de uma forma ah:... violenta... e ah: ah ah inclusive... afetando a

115 própria constituição né?... de modo que:: o que eu desejo nesse momento é de colocar o meu nome ao julgamento popular é só isso 
Logo que percebe a ameaça cometida por L2 (exemplo 6, linhas 88 a 90) à face dos eleitores, L1 (exemplo 7) recupera fatos ocorridos na época em que L2 havia sido eleito Presidente e chama a atenção de Collor para os efeitos provocados por seu enunciado "quando o senhor fala quatro ou cinco gatos pingados... o senhor está se referindo a maioria do congresso naquele momento... TAMBÉM eleito pelo povo assim como o senhor" (101 a 103), ameaçando, assim, as faces positiva e negativa do entrevistado. Ao identificar a crítica e a ameaça a sua face, L2 reformula seu enunciado através de um marcador de atenuação hedge “quer dizer" (linha 104), que sinaliza uma atividade de planejamento verbal e modifica o valor ilocutório do enunciado (Rosa, 1992).

O entrevistado (exemplo 7) chama a atenção de que valores positivos aceitos pela sociedade democrática foram transgredidos - “(...) do ponto de vista jurídico, né?... foi uma violência atrás de outra porque não foi me dado direito de defesa (...) de modo que as coisas foram acontecendo assim de uma forma ah:... violenta... e ah: ah ah inclusive... afetando a própria constituição né? (...)” (110 a 115) - e se dispõe a colocar seu nome a julgamento popular, confirmando a estratégia de que sua candidatura é um direito do povo.

Ao apresentar-se como aquele que sofreu com a violência do processo, Collor ameaça as faces positiva e negativa de seus interlocutores, colocando em dúvida o conhecimento deles - “(...) talvez não tenham parado uma pouco pra acompanhar todo esse processo(...)”. Porém, utiliza, estrategicamente, um marcador de atenuação hedge, “talvez" (linha 109), que provoca um efeito de incerteza e minimiza seu comprometimento com o enunciado, protegendo, assim, sua própria face (Rosa, 1992).

De acordo com os movimentos corretivos para se restabelecer o equilíbrio ritual, (Goffman, 1974), verificamos que a resposta dada por L2 (linhas 88 a 90; exemplo 6) consiste numa explicação em que tenta minimizar sua responsabilidade ao atribuir a "meia dúzia de gatos pingados" o fato de ter sido afastado do cargo. Porém, a explicação não é aceita por L1 
(linhas 100 a 103; exemplo 7) e um desafio é lançado no momento em que o entrevistador (L1) reconstrói, a partir de informações constituintes de seu conhecimento e de acordo com seu ponto de vista, o enunciado de L2. Groisman revela, através de seu enunciado (exemplo 7, linhas 100 a 103), que Collor provocou uma ameaça à face daqueles que votaram nos integrantes do Congresso.

No sétimo exemplo, é possível observar também que L1 constrói seu discurso (linha 101) a partir do enunciado proferido pelo entrevistado nas linhas 88 e 89 , exemplo 6. Para L2, as pessoas responsáveis pelo seu impeachment foram "meia dúzia de gatos pingados" (linhas 88 e 89, exemplo 6); para L1, essas pessoas constituem à "maioria do Congresso" (linha 102, exemplo 7).

Conforme Tannen e Wallat (2002), há, portanto, diferentes esquemas que resultam na mudança de enquadre provocada por L1 e faz em que L2 se realinhe de acordo com o novo enquadre: “me refiro/quer dizer é uma força de expressão"( linha 104, exemplo 7).

Assim, no momento em que o entrevistado L2 compromete-se com seu enunciado, inserida no discurso de L1 (linhas 101, exemplo 7), observamos a ocorrência do footing (Goffman, 2002): por meio da metadiscursividade, L2 reenquadra o que foi dito de acordo com o novo enquadre proposto por L1 ("me refiro/quer dizer" - linha 104, exemplo 7).

Verificamos que as estratégias argumentativas também se encontram presentes no exemplo 7: apesar de Collor tentar desvincular sua imagem do Congresso Nacional (exemplo 6), L1 utiliza um argumento de comparação (exemplo 7, linhas 102 e 103) em que enfatiza o advérbio "também" e, deste modo, aproxima a imagem de Collor à dos membros do Congresso Nacional: tanto o Congresso quanto Collor foram eleitos pelo povo "o senhor tá se referindo a maioria do Congresso naquele momento... TAMBÉM eleito pelo povo assim como o senhor?". 
Ao elaborar sua resposta (exemplo 7, linhas 105 e 106), o entrevistado novamente emprega um argumento pragmático para atribuir ao Congresso Nacional e a Ibsen Pinheiro a culpa pelo impeachment. Em seguida, (linhas 110 a 112), apela à regra de justiça (Perelman e Olbrechts-Tyteca, 2002:248) para dizer que o direito de defesa (reconhecido pelas nossas leis) não the foi concedido e reforça o argumento pelo sacrifício (op. cit: 280), já empregado anteriormente no exemplo 6, através do qual se dispõe a um julgamento popular.

\subsubsection{A aproximação}

Em seu Tratado da Argumentação, Perelman e Olbrechts-Tyteca (2002) destacam que é fundamental ao locutor, em qualquer argumentação, o conhecimento dos interlocutores que pretendem influenciar e, para isso, as técnicas que favorecem a comunhão entre orador e auditório podem atenuar uma possível oposição existente entre eles.

Nesse sentido, uma das técnicas argumentativas empregadas pelo entrevistador para se aproximar de seu interlocutor e, assim, proceder a uma argumentação mais eficiente, é o que Olerón (1983) denomina "similitude". Observamos, a seguir, que L2 utiliza várias vezes o pronome "nós" num enquadre em que ele se identifica com os problemas de seus interlocutores - "nós sentimos" (linha 156), "nós temos" (linha 160, 171, 172, 173), "nós nos lembramos"(linhas 162), "nós vemos" (linha 175) "ficamos" (linha 176) - e se inclui como parte das soluções: “é necessário nós fazermos mudanças” (linha 182).

(Exemplo 8)

155 L2: bom nós tamos viven::do... um momento... de extrema gravidade no país 
não é... todos nós sentimos nas nossas casa vocês sentem nas suas as dificuldades por que passa o país... nós temos hoje alguma coisa que a sociedade conquistou que é positiva... que é chamada a estabilidade monetária... mas acontece que essa estabilidade monetária... está sen::do... mantida a custa de um enorme sacrifício... nós temos hoje desemprego recorde no país... a saúde nunca esteve numa situação de calamidade como hoje se encontra... e nós nos lembramos que nos foi pedido o imposto do cheque... o chamado CPMF dizendo me dêem o CPMF que eu salvarei a saúde... o CPMF recolhe de seis a sete bilhões por ano... e desses recursos quase NAda vai para a saúde vocês aí alguns alguns são universitário né?... e sabem que hoje a universidade está relegada... a um plano secundário... quando a universidade num num mundo globalizado como está... tem que se a fonte de cérebros e de mãode-obra extremamente qualificada... para ajudar o país a competir nesse mundo globalizado... nós temos aí os aposentados sendo tratados com adjetivos e:: de forma pejorativa... nós temos aí o/ah:: os funcionários públicos que estão há quatro anos sem reajuste... nós temos aí os comerciantes... os empresários os industriais que estão quebrando estão falindo... por culpa desses juros extorsivamente altos que estão impedindo o país de progredir... enfim... e nós vemos aí esses efeitos todos causados pe/pe/pela po:lítica econômica e ficamos todos muito preocupados a crise que se abate sobre o país é séria o organismo econômico brasileiro está debilitado... e... portanto qualquer vírus que venha lá de fora seja da Ásia se/seja da Rússia vai pegar esse organismo debilitado... e pode sub/submeter a esse organismo a um processo duríssimo... de uma doença de difícil recuperação... por isso é que eu acredito que é necessário nós fazermos mudanças profundas... mantendo a estabilidade mas com desenvolvimento

Interessante notar que, logo no início, depois de utilizar o pronome "nós" (156), L2 se refere, a seguir, aos seus interlocutores pelo pronome "vocês", o que contribui para aproximar a jovem platéia e entrevistadores do assunto que está abordando e alinhá-los de acordo com o enquadre pretendido.

Percebemos também, no exemplo anterior (8), que Collor aponta vários aspectos negativos (como a CPMF - linhas 163 e 164) atribuídos ao governo do Presidente da República Fernando Henrique Cardoso e enfatizados pela expressão "nós temos” (linhas 160 a 173). Nesse momento, o entrevistado emprega uma figura de presença - a repetição - para evidenciar esses aspectos negativos. Outra estratégia argumentativa (exemplo 8) utilizada pelo entrevistado para depreciar o governo de Fernando Henrique Cardoso é a comparação do Brasil a um organismo debilitado, o que estabelece uma relação de igualdade (Perelman e 
Olbrechts-Tyteca, 2002: 275): “qualquer vírus que venha lá de fora seja da Ásia se/seja da Rússia vai pegar esse organismo debilitado... e pode sub/submeter a esse organismo a um processo duríssimo... de uma doença de difícil recuperação...” (linhas 178 a 181).

Esse posicionamento, contra as ações do governo de Fernando Henrique Cardoso, será mantido durante a entrevista, conforme observamos no exemplo seguinte (9), quando ao entrevistado é solicitado a divulgação de seu candidato num possível segundo turno, entre Lula e Fernando Henrique Cardoso.

(Exemplo 9)

195

L2: porque... o Lula e outro dia num programa de rádio... outro dia num programa de rádio... outro dia emBOra eu ache que num segundo turno estaremos novamente eu e Lula... mas num ((gritos da platéia)) num programa ((gritos da platéia)) me permitam dizer isso ((gritos da platéia)) bom ((silêncio)) mas deixa eu dizer... deixa/deixa eu dizer... então eu estava num...num programa... num programa de rádio num debate... e me perguntaram alguma coisa sobre o::... eleição e sobre:: o Lula ...e tal e eu me referi ao Lula como o companheiro Lula... e havia dentre os jornalistas dois que eram do PT... e eles intrigados com aquilo de 200 companheiro companheiro aí ele me pergunta... mas pera aí... como chamá-lo de companheiro... ele não é seu companheiro... aí eu disse engano seu... nós fomos companheiros no:: na campanha das diretas... nós fomos companheiros na disputa pela presidência em $89 \ldots$ e hoje somos companheiros na mesma visão crítica que TEmos... do governo

205 FHC... então não posso /posso dei/ é:: é:: deixar de dizer que eu me considero HOje... e nessas circunstâncias um companheiro... e falo...e falo que num segundo turno embora eu acredite... segura $\mathrm{e}$ sinceramente... que num segundo turno estaremos Lula e eu novamente reedidanto... a final de $89 \ldots$ se houver... se houver se...não der isso... e se 210 der Fernando Henrique e Lula... eu votarei em Lula para presidente

No exemplo 9, Collor procura uma aproximação da imagem popular de Lula, o candidato que, em 1998, era o principal opositor do governo de Fernando Henrique Cardoso. Assim, o entrevistado se intitula companheiro de Lula (linhas 202 a 204), numa referência aos ideais políticos positivos almejados pelos dois "nós fomos companheiros no:: na campanha das diretas... nós fomos companheiros na disputa pela presidência em $89 \ldots$ e hoje somos 
companheiros na mesma visão crítica que TEmos... do governo FHC...” (linhas 202 a 205, exemplo 9). A própria concepção da palavra "companheiro" utilizada por Lula ao tentar aproximar seu interlocutor do grupo formado por seu partido (Partido dos Trabalhadores PT) é alterada, de acordo com os objetivos de Collor: a palavra "companheiro", no exemplo 9, indica a participação de Collor e Lula em momentos importantes da história brasileira, como nas Diretas Já e nas Eleições de 1989. Desta maneira, podemos observar que Collor emprega a palavra "companheiro" sob um novo enquadre: no sentido de participarem juntos de alguns fatos históricos, mesmo que em partidos diferentes.

No exemplo seguinte (10), o entrevistado, sabendo que seus interlocutores e o públicoalvo do programa são jovens, procura aproximar-se de valores que presume serem positivamente aceitos entre os participantes do programa (linhas 315 e 316 ).

(Exemplo 10)

L2 (...) eu sempre fui uma pessoa dedicada a uma vida exTREmamente saudável... sempre fui... sempre fui... desportista... não é?... sempre pratiquei os meus esportes a vida ao ar livre e... nas vezes que eu posso 315 falar com pessoas como vocês eu sei que vocês gostam também muito de esportes eu digo olha minha gente... vão pro esporte vão pra fazer uma atividade física deixa essa coisa de droga de lado porque não leva... ninguém a nenhum lado... então eu quero é exaltar é exaltar a saúde... a condição e o condicionamento físico... como uma maneira que nós temos de administrar BEM... aquilo que Deus nos deu que foi o nosso corpo... se nós não administrarmos BEM... o nosso corpo cuidando da nossa saúde... nós não saber/ saberemos administrar nada na nossa vida.

Assim, para aproximar-se de seu público-jovem, define-se como uma pessoa saudável e, ao relatar seu gosto por esportes, L2 produz encaixamentos (Goffman, 2002) através do pronome "eu" (“eu digo" - linha 316; “eu quero" - linha 318), sinalizando mudanças de footing para novos enquadres: o locutor se projeta no discurso para aconselhar seu interlocutor ("eu digo" - linha 316 ) e, em seguida, indicar os benefícios que o esporte traz à 
saúde (“eu quero" - linha 318 )

No exemplo seguinte (11), identificamos que os entrevistadores possuem uma imagem do entrevistado e este, também, possui uma imagem de seus interlocutores, associando-os a uma categoria social (Goffman, 2004): são jovens que, assim como ele, quando pertencente a esse grupo, tinha atitudes consideradas parecidas em determinadas situações.

(Exemplo 11)

L2
(...) eu se tivesse na posição de vocês naquela oportunidade com aquela campanha da mídia eu seguradamente estaria também na ruas pedindo a deposição do presidente que fosse... então eu eu entendo perfeitamente tudo que se passou e entendo... a mobilização que foi feita com os jovens porque eu também já fui mobilizado... então ah: de modo que eu acredito que o povo brasileiro sim tenha memória... eu tenho memória por exemplo memória... exata de tudo o que aconteceu... desde que eu comecei di a::: na::: minha faixa dos quatorze quinze dezesseis anos... a participar de alguma forma da vida política do meu país (...)

Ao expor a imagem que faz de seus interlocutores por meio de seu discurso, o entrevistado procura semelhanças (linha 128) com o intuito de provocar a adesão de seu público pela similitude (Olerón, 1983). Porém, através dessa tentativa de proximidade, ele deixa transparecer sua interpretação para as ações do jovem: “porque eu também já fui mobilizado" (linhas 132/133) e provoca uma ameaça às faces positiva e negativa de seus interlocutores quando diz: "eu entendo perfeitamente tudo que se passou e entendo... a mobilização que foi feita com os jovens porque eu também já fui mobilizado..." (linhas 131 a 133). 
Assim como o entrevistado possui uma pré-imagem de seus interlocutores que se confirma ou se reconstrói ao longo da interação verbal, os entrevistadores e a platéia também possuem uma imagem do entrevistado que é revelada através do enunciado das perguntas. Conforme veremos, nos exemplos seguintes (12 a 22), por meio das perguntas, os entrevistadores associam a imagem de Collor a valores negativos, como à falta de moral, de consciência e ao uso da manipulação e da mentira para conquistar seus objetivos.

No exemplo seguinte (12), a manipulação é o tópico proposto pela locutora L12, que identifica, no desejo de Collor em se candidatar novamente, uma ameaça às faces positiva e negativa daqueles que foram a favor de seu impeachment.

(Exemplo 12)

L12 é:: eu quero saber se::::assim/se:: quer se submeter a um julgamento popular agora né?... então eu quero saber se você não acha... que:: $\underline{\text { o seu }}$ poder de persuasão é maior que a capacidade de discernimento do povo que não tem cultura e não tem e...ducação necessária pra/e é facilmente manipulado? ((gritos e aplausos do auditório))

L2 veja que:: ((gritos do auditório)) você me atribui um poder de persuasão que eu não sei se tenho... o que eu sei que tenho obrigado ((risada do locutor e aplausos do auditório)) agora... agora... agora pessoal... o que eu sei que tenho é o seguinte... é o que muitos de vocês têm... eu não sei fazer nada na minha vida que não seja com paixão... com ardor e ((risos e gritos do auditório)) com vontade ((risos e gritos do auditório)) não não a paixão piegas ((risos)) não... não... cês estão entendendo... não é essa paixão não é essa paixão piegas paixão piegas é uma paixão no sentido de me dedicar inTEgralmente àquilo que eu tô fazendo... então... então... às vezes... às vezes... vocês é como ela entende a persuasão... ah:: talvez seja a vontade que eu tenho de transmitir a Minha verdade cada um tem a sua verdade... (...) 
O entrevistador L12 (323 a 327; exemplo 12) chama a atenção para a ameaça que se explicitou no enunciado anterior de L2 (exemplo 11). Juntamente com o desafio lançado ao entrevistado (Goffman, 1974), a locutora L12 ameaça as faces positiva e negativa de seu interlocutor quando lhe atribui a idéia de que o povo, seus eleitores, não possuem cultura e educação e são manipulados facilmente (linhas 326 e 327).

No momento em que o entrevistado percebe a ofensa, ele também provoca um desafio, amenizando, através do marcador de atenuação hedge "eu não sei se" (linhas 329), uma potencial ameaça a sua face e a de seu interlocutor. Assim, o entrevistado coloca em dúvida o conhecimento de seu interlocutor, mas não se compromete inteiramente com o que foi dito (Rosa, 1992).

No exemplo 12, constatamos, também, uma das modalidades metadiscursivas (Risso e Jubran, 1998): a inserção de um discurso alheio como objeto de interpretação e avaliação. O entrevistador L12 insere a fala do entrevistado em seu enunciado como objeto de conclusão “se:: quer se submeter a um julgamento popular agora né?..." (linhas 323 e 324) para formular a pergunta posterior.

O interlocutor L12, ao comprometer o entrevistado com o que disse, cria um enquadre de um político que menospreza o seu eleitorado. Porém, o entrevistado promove um realinhamento ao tentar mudar o enquadre criado por L12, utilizando em recurso metadiscursivo quando traz para seu enunciado uma avaliação do discurso produzido por L12: "você me atribui um poder de persuasão que não sei se tenho" (linhas 328 e 329).

$\mathrm{Na}$ linha 333, Collor provoca uma outra mudança de footing sinalizada pelo marcador metadiscursivo "o que sei que eu tenho é o seguinte". Sendo assim, L2 muda o enquadre "persuasão" construído por L12 e constrói um novo "é paixão e vontade” (linhas 334 e 335, exemplo 12), não aceito pela platéia que produz gritos e risadas (335 a 336). 
O locutor L2, percebendo que não foi compreendido como pretendia, reconstrói seu enunciado para conseguir a interpretação desejada para o seu novo enquadre: "não a paixão piegas ((risos)) não... não... cês estão entendendo...(...) é uma paixão no sentido de me dedicar inTegralmente àquilo que eu tô fazendo...” (linhas 333 a 335, exemplo 12).

A seguir, provoca uma ameaça às faces positiva e negativa de L12, ao indicar que o enquadre definido pela entrevistada não é adequado para o sentido da palavra persuasão: "vocês é como ela entende a persuasão...ah:: talvez seja a vontade que eu tenho de transmitir a MInha verdade" (linhas 339 e 341).

No exemplo (13), o tópico "manipulação" é novamente retomado pelo próximo entrevistador, ocasionando uma outra ameaça às faces positiva e negativa do entrevistado. Porém, se no exemplo 12 encontramos um enquadre referente a quem é manipulado - "povo manipulado"; no exemplo 13, a manipulação aparece num outro enquadre, relacionado ao manipulador - "manipulação da TV".

(Exemplo 13)

L13 já que tava falando de manipulação... eu queria saber se... você não acha que se não tivesse sido tão ajudado pela Rede Globo... principalmente no seu último debate com o Lula que foi editado para ser passado no Jornal 370 Nacional se o senhor teria ganhado as eleições? ((gritos e aplausos do auditório))

No próximo exemplo (14), o entrevistado, para responder a pergunta de L13 (exemplo 13), emprega uma estratégia argumentativa em que compara e qualifica sua atuação no primeiro e no segundo debates, a fim de mudar o enquadre (a ajuda da Rede Globo) criado pela entrevistadora (exemplo 14, linhas 411 a 413). Através dessa estratégia, Collor propõe um novo enquadre, de acordo com seus objetivos: o último debate lembrado pelas pessoas foi 
aquele em que teve uma melhor atuação.

Entretanto, ao constatar que a resposta do entrevistado (linhas 408 a 413) não foi satisfatória, o locutor L13 propõe um desafio (linhas 414 a 417), na tentativa de provocar um realinhamento do entrevistado para que possa entender o enquadre da pergunta (linhas 367 a 371, exemplo 13).

(Exemplo 14)

L2

(...) então é difícil haver manipulação quando a transmissão é ao vivo... que manipulação pode haver?... nenhuma manipulação eu acredito que o o::: o fundamentalmente o que::: o que houve... o que houve... o que houve do mesmo modo que no primeiro debate eu não fui bem... no segundo debate eu acho que fui melhor que 0 Lula... então o que ficou foi a impressão do último debate

L13 mas a edição que eu estou falando é::um resumo que foi feito pra ser passado no Jornal Nacional... eles fizeram um resumo de seis minutos... que passou::: praticamente :: um minuto a mais do senhor falando que o Collor/que o Lula

L2 bom isso aí eu não não imaginei não peguei não sei ((vais do auditório)) mas fundamentalmente o que houve foi isso quer dizer o debate passou ao 420 vivo... o debate passou ao vivo

Conforme Tannen e Wallat (2002), o entrevistado demonstra possuir um esquema diferente daquele de sua entrevistadora (linhas 418 a 420, exemplo 14) e não responde à pergunta de acordo com o enquadre reforçado pelo locutor L13, às linhas 414 a 417, exemplo 14.

No exemplo seguinte (15), o entrevistador aproxima a imagem de Collor às oligarquias do Nordeste. 
L15: senhor presidente... eu queria::: bem/ você pelo jeito que tá... criticando o Fernan/Fernando Henrique você deve... querer algumas mudanças né?... 480 e eu gostaria de saber como você pretende fazer isso... partindo de uma família oligárquica do nordeste...(...)

O entrevistador, L15, avalia em seu enunciado o discurso do entrevistado "você pelo jeito ta... criticando o Fernan/Fernando Henrique" (linhas 479 e 480) e, em seguida, tira suas conclusões a respeito do que falou L2 "você deve... querer algumas mudanças" (linha 479). Num primeiro enquadre, o entrevistador alinha-se com a fala do entrevistado, ao definí-la como uma crítica, porém, logo em seguida, L15 promove um realinhamento, ao demonstrar que o desejo de mudanças, expresso no discurso de L2, não será possível, devido à incompatibilidade entre o que Collor representa (membro de uma família oligárquica do Nordeste - linha 481) e o que pretende (mudanças no governo - linha 479).

Nesse exemplo, conforme explicação de Orecchioni (1992), o locutor L15 ameaça às faces de Collor, positiva (correspondente ao seu reconhecimento social) e negativa (relacionada a sua posse - minha família), ao associá-lo como membro pertencente a uma família oligárquica do Nordeste, ou seja, a imagem do entrevistado é relacionada a um valor socialmente negativo entre os brasileiros.

No segmento do exemplo seguinte (16), o locutor L16 aponta incoerências nas respostas de Collor, sinalizado pelo marcador metadiscursivo "ó... algumas é... incoerências aqui no seu discurso" que atribui um valor negativo ao discurso de Collor (é incoerente) e provoca uma ameaça as suas faces positiva e negativa.

(Exemplo 16)

L16: ó... você falou aqui... que::.... ó... algumas é... incoerências aqui no seu discurso tá... você falou da equipe econômica do Fernando Henrique mas muitos membros da equipe econômica do Fernando Henrique foram... membros da sua e/equipe econômica como o Candir tá... o:: o... Renan 
500

505

510

515
Calheiros que é o ministro da:: da:: justiça que... cê acabou de citar como... que você... não foi é:::: culpado pela justiça não sei o que foi é :: teu colega de Alagoas é ministro da:: da justiça lá... você também falou do congresso nacional... só que no segundo turno da eleição... é::: a grande maioria do congresso... foi a favor seu... principalmente o PFL ou na época o PDS né? toda a bancada deles eram a seu favor... e você tinha maioria do congresso no começo do governo... e outra coisa... você falou que... por falta talvez de memória nossa aqui... você era um considerado um azarão na campanha de $89 . .$. mas desde da convenção do PMDB por exemplo:: você já... já estava em primeiro lugar na... na eleição na pesquisa com que... pra/ explicar que a convenção do PMDB foi feita na mesma época que/que tamos hoje aqui pra eleição mais ou menos... você já era já era o primeiro lugar empatando_com o Quércia né? na::: época na época daí elegeram o Ulisses Guimarães na convenção então você não era você não foi um azarão você falou que no no segundo turno as pessoas não votaram em você... porque::você tava ah:: é ...não:: ia:: é:: votar votavam em você porque não iam votar no Lula... só que desde o primeiro turno você já tinha quarenta porcento dos votos... tá e agora eu vou fazer uma pergunta pra você ((risos de Collor e aplausos do auditório))(...)

Conforme Perelman e Olbrechts-Tyteca (2002), um locutor pode perder todo seu prestígio e toda sua credibilidade se os seus interlocutores desconfiarem de que seu discurso não seja verdadeiro. Deste modo, a argumentação é enfraquecida na medida em que os interlocutores suspeitam de um discurso dissimulado, que deixa de preencher o critério ético, determinado por um contrato implícito na prática de uma comunicação política e democrática (Halliday, 1994:99).

O locutor L16 aponta várias contradições no discurso de Collor criando um enquadre "mentiras", em que L2 fica totalmente desacreditado. Em seguida, provoca uma mudança de footing, através de um recurso metadiscursivo "agora eu vou fazer uma pergunta pra você" (linhas 517/518), para determinar um novo enquadre "pergunta". Com o advérbio "agora", o locutor indica ciência de que até o momento não obedeceu a tarefa destinada ao entrevistador - realizar perguntas - e avalia seu próprio enunciado que vem a seguir: agora é o momento da pergunta. A quebra do contrato de comunicação é percebida também por seus interlocutores, que sinalizam com risos e aplausos (linhas 518/519).

Com o intuito de tornar a argumentação mais eficaz, o entrevistador utiliza uma figura 
de presença em que enumera as incoerências do discurso de L2. Observamos, também, que o marcador metadiscursivo "você falou" assinala as quatro incoerências apontadas por L16, às linhas $497,502,506,514$.

A seguir, nos exemplos 17 e 18, selecionamos outros trechos em que os entrevistadores, ao realizarem suas perguntas, revelam suas opiniões a respeito de Collor, provocando um desvio da função de entrevistadores (Rosa, 1992).

(Exemplo 17)

L14: primeiro eu queria dizer que eu tenho esperança de que você não vá para o segundo turno... e depois eu queria saber que:: você gostando tanto da natureza por que o senhor não fez nada pelo meio ambiente e:::

O locutor L14 também organiza seu discurso com recursos metadiscursivos "primeiro eu queria dizer" (linha 421) e "e depois eu queria saber" (linha 422). Com isso, ele provoca dois encaixamentos, sinalizando duas mudanças de footings, o primeiro para enquadrar a sua opinião e a segunda mudança para realizar a pergunta como função discursiva da entrevistadora.

Neste exemplo (17), L14 aponta, estrategicamente, uma incompatibilidade entre o discurso de Collor (de que gosta da natureza) e seu ato (não fez nada pelo meio ambiente), o que provoca uma ameaça às faces positiva e negativa do entrevistado.

Já no exemplo seguinte (18), o locutor (L8) propõe o enquadre legalidade X moralidade em que, por meio de um marcador metadiscursivo "o senhor fala que" (linha 225), insere o discurso de Collor em seu enunciado para, em seguida, provocar uma ameaça à face positiva e negativa do entrevistado (L2). 
(Exemplo 18)

225 L8: com certeza o senhor fala que... foi investigado sua inva/éh:: sua privacidade foi invadida e tal... só que a maioria dos brasileiros não...o consideram inocente eu queria saber como o senhor lida com isso de... legalmente sendo inocente mas... é... moralmente eu acho que não é por aí ...entendeu ((aplausos e gritos))

230 L2: veja...((gritos do auditório)) veja... ((gritos do auditório)) veja... ((gritos do auditório)) é pra isso é pra isso que existe uma eleição... entende é pra isso que existe uma eleição ah:: e é pra isso que eu desejo ouvir... a resposta popular nas urnas... quer dizer você fala e com toda... e com toda a propriedade que o :: que o seu entendimento... ah:: merece... de que esse não é seu entendimento... mas vamos vamos ouvir... o conjunto da população... e é exatamente essa resposta que eu estou buscando... eu estou buscando... nas URNAS a resposta da população brasileira... a essa dúvida que alguns segmentos ainda têm... e eu desejo democraticamente submetendo o meu nome a julgamento popular... ter esse julgamento popular... nas eleições de 98

Ao responder a pergunta formulada por L8 (exemplo 18), o entrevistado recorre, pela terceira vez na entrevista, aos valores como democracia, direito e julgamento e ao emprego do argumento pelo sacrifício (ele coloca-se à disposição de um julgamento popular para garantir o direito do povo - exemplo 6). Porém, considerando a próxima pergunta, percebemos que o enquadre proposto por Collor (sua candidatura é um julgamento popular), pela terceira vez, não é aceito pelo entrevistador L9, ao afirmar que "cento e cinqüenta milhões de pessoas te odeiam" (linhas 248 e 249).

(Exemplo 19)

L9: senhor senhor ex-presidente eu queria saber do senhor... sem muita auto propaganda... se:: o senhor dorme tranqüilo sabendo mesmo sabendo que:: cento e cinqüenta milhões de pessoas te odeiam? ((gritos e aplausos da platéia))

Assim, L9 destrói o enquadre criado por L2, pois, se Collor for tão desprezado como L9 diz que é, a justificativa de Collor para candidatar-se novamente (julgamento popular) não 
seria necessária.

O locutor L9 (exemplo 19) enfatiza o enquadre proposto por L8 "falta de moralidade" (exemplo 18) e reforça a ameaça às faces positiva e negativa do entrevistado que, por sua vez, insiste novamente, durante a entrevista, em dizer que sua candidatura é um modo de julgamento popular (exemplo 20).

(Exemplo 20)

250 L2: não não exagera ((gritos da platéia)) ((risadas)) não exagera não exagera cento e cinqüenta milhões não até porque... no/ nós temos que... ((barulho e risada de L2)) veja bem... não é... e é por isso é ser isso que eu desejo... eu:: eu repito né? é por isso que eu desejo submeter o meu nome a julgamento popular porque eu desejo saber... realmente... qual é 255 o julgamento popular... sobre o meu período como Presidente da República e sobre as expectativas que eu posso despertar ainda no seio da população em relação ao nosso futuro... é essa a resposta que eu busco

O entrevistado reformula seu enunciado através do marcador hedge "veja bem" (linha 252). Deste modo, L2 solicita a atenção do interlocutor e atenua uma ameaça à face positiva e negativa do interlocutor, que ainda não aceitou seu enquadre "julgamento popular". Interessante notar que o próprio entrevistado reconhece a repetição de um mesmo argumento (de sacrifício) e compartilha com os interlocutores essa constatação: “eu repito né?" (linha 253).

Depois do discurso de apresentação realizado por L2 (linhas 61 a 99; exemplo 6) para reconstruir sua imagem, não há adesão do público, pois, nas perguntas formuladas no exemplo 21 (linhas 119 a 121) e 22 (linhas 669 a 671), verificamos que seus atos passados são constantemente associados a valores reconhecidos como negativos pela sociedade. No exemplo (21), a entrevistadora expõe, em seu discurso, a concepção de público transmitida 
por L2 ao propor sua candidatura: "o brasileiro não tem memória”(linha 119).

(Exemplo 21)

L5: é... o senhor acredita no dito popular que o brasileiro não tem memória por isso o senhor está se ree/candidatando ....a propósito o senhor tem memória?((aplausos e gritos do auditório))

(Exemplo 22)

670

L17: durante as eleições em $89 \ldots$ você falou que o Lula ia confi/ confiscar as poupanças e quem acabou fazendo isso um dia depois de ser eleito foi você... cê acha que um:: candidato POde mentir para ser eleito ou omitir?

A imagem de L2 (exemplo 22), influenciada pelos atos passados, é o ponto de partida para pressupor seus atos futuros. Assim, podemos constatar que a imagem do entrevistado adquire uma estabilidade, pois, se não foi sincero uma vez, poderá não o ser novamente (Perelman e Olbrechts-Tyteca, 2002). A pergunta elaborada no exemplo (22) indica uma desvalorização da imagem do entrevistado (linhas 669 a 671), que é associada a valores negativos, como a mentira e a omissão de informações. Esses valores atribuídos aos seus atos colaboram para pressupor o caráter do entrevistado.

O entrevistado busca a adesão de seu público e a construção de uma imagem confiável, porém, seus atos passados sempre são retomados por meio das perguntas de seus entrevistadores como atos associados à falta de competência, o que contribui para desfazer a credibilidade em seu discurso atual (op. cit.).

No exemplo 21, é possível constatar que o entrevistador ameaça tanto à face positiva quanto à face negativa do entrevistado, ao atribuir-lhe falta de memória e crença em um ditado popular (linhas 119 a 121). Porém, ao ameaçar a face de seu interlocutor, L5 produz, também, uma ameaça a sua face positiva e negativa, pois a própria existência desse dito 
popular já ameaça a face de todos aqueles que são brasileiros.

4.3 O mediador no papel de entrevistador

Em alguns momentos, o mediador se ajusta na posição de entrevistador, o que ocasiona uma mudança em seu status (Goffman, 2002): de participativo de platéia (conjunto de ouvintes ratificados a quem a fala é direcionada) transforma-se em ouvinte ratificado endereçado (aquele a quem a fala é dirigida especificamente) ${ }^{22}$. Ao mudar seu status, L1 deixa de ser um mediador e transforma-se em entrevistador, alinhando-se, portanto, de acordo com o novo enquadre criado.

Vejamos os exemplos abaixo:

(Exemplo 23)

L1: agora...é...na hipótese... do senhor (poder) se candidatar poder se candidatar através do TSE e numa hipótese... de um segundo turno ah::é::exsistir o que existe hoje uma:.... uma::... uma briga bem forte entre Lula e Fernando Henrique... no segundo turno... em quem o senhor votaria?

(Exemplo 24)

L1: agora é verdade que:::esse governo comparati/tô aqui ((se levanta)) comparativamente esse governo tem feito MUIto... em relação ao governo ::: que o senhor teve em relação à reforma agrária

22 No momento em que o entrevistado responde uma pergunta elaborada pelo mediador, esse assume o status de ouvinte ratificado endereçado, já os adolescentes presentes no programa e os telespectadores possuem o status de platéia. 
L1:

famílias foram assentadas isso isso é<smiles>CCCC</smiles>

L2:

L1: uma verdade né?

No exemplo 24, o mediador emprega uma estratégia argumentativa (a comparação) e provoca ameaça às faces positiva e negativa do entrevistado, ao comparar o governo de Collor com o de Fernando Henrique Cardoso (FHC). Assim, L1 determina um enquadre - o governo de FHC fez mais do que o governo de Collor em relação à reforma agrária - em que L2, ao responder (exemplo 25), propõe um reenquadramento da informação, através de um recurso metadiscursivo em que avalia o enunciado de L1 (exemplo 24) como uma contradição encontrada no governo de Fernando Henrique Cardoso, "veja que paradoxo" (linhas 640). Nesse reenquadramento, uma nova comparação é realizada, porém, o entrevistado enfatiza o aspecto negativo de seu opositor, a revolta dos sem terras (exemplo 25).

(Exemplo 25)

640 L2: é uma verdade agora veja um:: veja que paradoxo veja que paradoxo o o::: governo FHC... foi aquele que mais assentou... sem dúvidas... foi o que mais assentamentos fez... bom e se é o governo que mais assentamentos fez... por que... hoje estamos assistindo a essa enorme revolta dos sem terras? não há aí um paradoxo?... porque se é o governo que mais assentamentos fez... então se deveria dar a ele um certo crédito... e deveria o movimento estar de alguma forma satisfeito porque está vendo a proposta da reforma agrária avançar... e por que nunca o clima... no:: na região na zona rural o clima no interior nunca esteve... TÃO tão grave nunca esteve TÃO aceso nunca as paixões ficaram desen/ desencadeados de uma maneira TÃO forte... por quê? porque o programa de reforma agrária não está sendo feito da forma que deveria ser feito... não adianta a gente a gente chegar numa fazenda retaliar e dizer você então fica com este pedaço de terra você fica com este e você com aquele... o que... o que tem que se fazer é ao mesmo tempo em que se dá 
a terra tem que se dá a semente... tem que se dar o apoio técnico para plantar... tem que se ter uma política de preços mínimos para garantir... a remuneração do:: de que ele vai produzir... tem que haver as vias de escoamento para poder retirar a safra de onde está para os locais de distribuição... tem que haver também uma mínima infra-estrutura... para 660 que ele possa manter o assentado possa manter a sua família... tem que ter um posto de saúde tem que ter uma escola porque senão o que ele vai fazer naquele meio de mundo... com a mulher com os filhos e ele sem/se tiver uma doença não tem onde levar se o filho... o filho quer estudar e não pode... então o que falta é exatamente isso é uma consciência... 665 global... do problema da reforma agrária... e esse governo embora tenha feito/ foi o que mais distribui foi o que mais assentou... foi e::e:: não está dando resultado por quê? porque não está dando a infra-estrutura mínima necessária... para que esses assentamentos possam funcionar a contento

O novo enquadre (exemplo 25) é reforçado por 3 perguntas retóricas (linhas 643 a 644, 647 a 650, 666 a 667) que enfatizam contradições apontadas nas ações do governo Fernando Henrique Cardoso. Mais adiante, Collor indica, através da expressão "tem que" (linhas 654 a 661), ações positivas que o governo não realizou e que seriam a causa da contradição encontrada no governo de FHC. Deste modo, Collor constrói um enunciado em que, por meio de estratégias argumentativas (perguntas retóricas e contradições) e uma figura de presença (enumerações), ameaça a face de Fernando Henrique Cardoso, Presidente da República em 1998 e candidato à reeleição na época.

\subsection{Conclusão das Análises}

As análises permitiram-nos constatar como estratégias discursivas (interacionais e argumentativas), recursos lingüísticos (metadiscursos) e conhecimentos cognitivos (esquemas) são processados on-line pelos interactantes, numa entrevista televisiva, a fim de atingirem seus objetivos. 
$\mathrm{Na}$ entrevista analisada, observamos que o entrevistado tentou (re)construir uma imagem próxima a valores positivos reconhecidos socialmente que possibilitassem seu retorno à política. Porém, os valores negativos, associados a sua imagem, persistiram nas perguntas elaboradas pelos jovens entrevistadores do Programa Livre e comprometeram os propósitos de reconstrução de uma imagem desgastada pelo impeachment, almejada pelo entrevistador, Fernando Collor de Melo, através da interação verbal na entrevista televisiva.

Portanto, várias são as vezes em que encontramos ameaças à face positiva, ou seja, aquela em que os interlocutores preocupam-se em manter socialmente; e ameaças à face negativa, aquela em que o território pessoal é invadido (corporal, espacial ou temporal; bens materiais e conhecimentos).

Para defender sua face e reconstruir sua imagem social, Collor buscou, estrategicamente, aproximar-se de seus jovens interlocutores e de outros indivíduos reconhecidos de algum modo pela sociedade, como Getúlio Vargas e Lula; ou transferir a terceiros a responsabilidade pelo impeachment que sofreu (ao Presidente da Câmara dos Deputados, Ibsen Pinheiro, ou aos "anões do orçamento"). Em outras oportunidades, propôs uma relação entre sua candidatura e valores aceitos pela sociedade, como direito, democracia, justiça e julgamento popular.

Sobre as questões referentes à situação política da época, o entrevistado ora reforçou aspectos negativos do governo de Fernando Henrique, apontando problemas relacionados ao governo; ora reforçou aspectos positivos de si mesmo, indicando sugestões, a fim de amenizar os efeitos causados por tais problemas encontrados. Diante disto, o entrevistado articulou estratégias em que desqualificou o Presidente da República, ao mesmo tempo em que privilegiou suas próprias ações, aproximando-as de valores positivos.

Ao observarmos as estratégias argumentativas, verificamos que Collor utilizou argumentos de autoridade, de comparação, de reciprocidade, de direção, de sacrifício, de 
contradição, argumentos pragmáticos, regras de justiça e, para fortalecer o valor argumentativo, empregou figuras de presença - como a sinonímia e a repetição - e figuras de comunhão, em que tentou se aproximar de valores aceitos pelos seus interlocutores. Quando lhe foi favorável, utilizou a técnica de ruptura para dissociar sua imagem de alguns grupos sociais negativos (como o dos "anões do orçamento") e perguntas retóricas para orientar a argumentação conforme seus objetivos (conforme verificamos no exemplo 25).

Ao perceber que as perguntas realizadas pelos entrevistadores ameaçavam sua face, provocando um enquadre não compatível com a linha de conduta assumida, Collor procurava, através de recursos metadiscursivos, uma mudança de footing, em que insistia na construção de um enquadre compatível com seus objetivos: sua candidatura é um julgamento popular.

É assim que o entrevistado, ao ver sua face ameaçada, promoveu um reenquadramento de conceitos como "manipulação" e "persuasão" e acabou por provocar uma ameaça às faces de seus interlocutores, ao colocar em dúvida o conhecimento deles.

Apesar de utilizar marcadores de atenuação ao defender-se de acusações, o entrevistado não conseguiu amenizar as ameaças às faces de seus entrevistadores, o que pudemos constatar pela elaboração de perguntas que: utilizaram o discurso de Collor para provocar uma ameaça a sua face; apontaram incoerências no discurso do entrevistado, desqualificando-o perante seu público; retomaram atos negativos cometidos em seu passado; demonstraram incompatibilidade entre Collor e o que ele representa (família oligárquica); associaram sua imagem à mentira, à falta de moral e consciência.

Sendo assim, constatamos que Collor empregou estratégias interacionais para preservar sua face e estratégias argumentativas a fim de modificar a opinião de seus interlocutores a respeito de sua imagem pública; entretanto, encontrou uma grande resistência por parte dos entrevistadores que não aceitaram os enquadres relacionados a sua apresentação, a suas justificativas para o impeachment e a seu propósito em candidatar-se novamente. 
CONCLUSÃO 
Este trabalho teve por proposta o estudo dos papéis sociais desempenhados pelos indivíduos durante uma interação verbal específica - um programa televisivo em que um personagem da política nacional é entrevistado - para observar o jogo discursivo que se institui entre entrevistadores jovens e um político que quer reconstruir sua imagem, perante os telespectadores.

Para a realização das análises consideramos que a interação verbal possui regras sociais aceitas pelos interactantes e determinadas pelo gênero em questão: a entrevista televisiva. Essas normas comunicativas influenciam as escolhas discursivas dos interactantes (entrevistadores e entrevistado) que buscam construir ou reconstruir uma imagem compatível com valores positivos reconhecidos pelas sociedades em que estão inseridos.

Verificamos que o entrevistado, foco de nossa análise - ex-presidente da República, Fernando Collor de Melo, afastado pelo processo de impeachment - marcou negativamente sua imagem na sociedade brasileira.

Foi possível observar que o interactante, numa linha de ação coerente com seus objetivos, projetou uma definição da situação em que informou, a seus interlocutores, como deveria ser interpretada sua imagem (Goffman, 2004); entretanto, os outros interactantes não aceitaram e provocaram constantemente uma mudança de footing (Goffman, 2002), ou seja, uma mudança na projeção do eu, um realinhamento de postura que ocasionou novos enquadres (sentido construído em uma interação).

Com o intuito de se prevenirem em relação a novos enquadres que colocassem em risco a linha de conduta que se apresentava, práticas preventivas (defensivas e protetoras) foram utilizadas para evitar a quebra dessas projeções iniciais. Assim, constatamos que os interactantes utilizaram estratégias interacionais para protegerem o que Goffman (1974) definiu como face, ou seja, um valor social positivo que as pessoas atribuem para si, através 
de determinada linha assumida, em um encontro social.

Durante a entrevista, Collor utilizou-se de estratégias discursivas, selecionadas para promover uma mudança de opinião em seus interlocutores (os jovens entrevistadores) de tal modo que modificassem sua imagem abalada por incidentes políticos. Porém, em uma interação face a face sucedida num programa televisivo, precisamos considerar um contexto nos quais telespectadores, auditório, entrevistadores e mediador não constituem figuras de ouvintes passivos, mas sim de participantes de uma interação em que interpretam e reagem, discursivamente, aos enunciados construídos por seus interlocutores e, para isso, utilizam-se, também, de estratégias discursivas que contribuem para a afirmação de suas ideologias, crenças, valores e opiniões a respeito dos tópicos desenvolvidos.

Como pudemos verificar, Collor, ciente de sua imagem desgastada pelos escândalos políticos e, principalmente, pelo impeachment, procurou reconstruir uma imagem associada aos valores que pressupôs serem aceitos pelos entrevistadores e pelos telespectadores. Para isso, ele precisou conhecer características que definiram a imagem de seus interlocutores (entrevistadores e telespectador) e que contribuíram para a construção de seu discurso.

Assim, com o intuito de reconstruir a imagem negativa que lhe havia sido atribuída, Collor expôs sua face e, apesar das estratégias discursivas por ele relacionadas para a consecução de tal objetivo, os entrevistadores não deixaram de associar sua imagem às ações negativas praticadas à época em que foi Presidente da República.

Pode-se dizer que a tarefa de convencer o público jovem que participava do programa não foi tão pacífica assim, porque, através das perguntas direcionadas a Collor, a imagem de um político corrupto, envolvido no processo de impeachment em 1992, era sempre retomada pelos entrevistadores, numa situação em que ameaças às faces contribuíram para uma situação de conflito. 
A partir das análises, constatamos que entrevistador e entrevistados praticaram, durante a entrevista, um jogo interacional em que ameaças às faces e estratégias de preservação foram constantemente utilizadas. Em relação a Collor, verificamos que não só defendeu sua face das ameaças realizadas pelos entrevistadores, como também, através de estratégias argumentativas, procurou exercer uma mudança de opinião atuando no sistema de conhecimento de seus interlocutores. Porém, ao administrar estratégias interacionais e argumentativas para reconstruir sua imagem desgastada pelo impeachment, ele iniciou um jogo em que acabou por ameaçar também a face de seus interlocutores.

Os entrevistadores, por sua vez, ao notarem as ameaças as suas faces, solicitavam o processo corretivo, ora realizado de modo satisfatório pelo entrevistado, ora não aceito pelo entrevistador. Observamos, enfim, que ao elaborarem suas perguntas, os entrevistadores associaram os atos passados de Collor a sua falta de competência e a valores negativos, o que frustrou a tentativa do entrevistado de recuperar sua credibilidade e legitimidade por intermédio de estratégias discursivas (interacionais e argumentativas). Assim, a própria presença de Collor apresentou-se uma ameaça à face de seus interlocutores e sua tentativa de candidatar-se, novamente, pôs em risco a face de um público que apoiou o processo de impeachment.

Constatamos, também, que o mediador tanto desempenhou o papel de organizador da entrevista quanto se colocou no papel de entrevistador, elaborando questões ao entrevistado e, através de suas perguntas, apontou valores negativos atribuídos à imagem de Collor.

Os telespectadores constituem a razão pela qual acontece a entrevista, pois, entrevistadores, mediador e entrevistado constroem seus enunciados baseados na pressuposição dos anseios e objetivos desse público. Assim, encontramos na entrevista televisiva analisada um jogo de oposições e cooperação, pois, de um lado, um discurso entre entrevistadores e mediador foi construído pela oposição ao entrevistado; por outro lado, esses 
entrevistadores, mediador e entrevistado realizaram, juntos, numa atividade cooperativa, um discurso destinado a satisfazer os desejos de um público telespectador que assistia à entrevista. Deste modo, a imagem atribuída aos telespectadores foi determinante na escolha de estratégias que alcançassem os objetivos dos participantes da interação verbal.

Pelo exposto, constatamos que as questões apontadas na introdução deste trabalho foram contempladas de acordo com os estudos da Sociolingüística Interacional - em que se destacaram os referentes à preservação da face. Observamos, ainda que, a compreensão do discurso - em relação à linguagem e ao universo interacional - enriquece-se e se completa ao associarmos aos aportes teóricos da Sociolingüística Interacional, os da Teoria da Argumentação. Assim, observamos conjuntamente essas duas teorias que, apesar de apresentarem direcionamento específico, podem se aproximar em vários pontos, como: a importância do reconhecimento do auditório ou do público a quem se destina o enunciado, a influência do ato (verbal ou não) na caracterização de um interactante, a existência de um acordo interacional entre os participantes de uma interação verbal, a relativa estabilidade atribuída ao interactante, a desqualificação e o descrédito associados ao discurso considerado frágil pelos interlocutores, a importância do reconhecimento de valores de uma sociedade para a elaboração do discurso durante uma interação verbal - constatação significativa a que nos levou essa pesquisa. 


\section{BIBLIOGRAFIA}


ABREU, A. S. A arte de argumentar. Cotia: Ateliê Editorial, 1999.

ABREU, M.T.V. A repetição como recurso argumentativo no discurso político. Estudos Lingüísticos XXVII. São José do Rio Preto, p. 475-478, 1998.

ANDRADE, M.L.C.V.O. O discurso da mídia: interações nas entrevistas de TV. Linha d'Água. São Paulo: Humanitas, n. especial, p. 73-77, jan. 2000.

ANDRADE, M.L.C.V.O. Relevância e contexto - o uso de digressões na língua falada. São Paulo: Humanitas, p. 111-147, 2001.

AQUINO, Z.G.O. Conversação e conflito: um estudo das estratégias discursivas em interações polêmicas. Tese de doutorado. FFLCH/USP, 1997.

BAKHTIN, M. Marxismo e filosofia da linguagem. 4.ed. São Paulo: Hucitec, 1988

. O enunciado, unidade da comunicação verbal. In: Estética da Criação Verbal. São Paulo: Martins Fontes, 2003.

. O problema do texto. Observações sobre a epistemologia das ciências humanas. In: Estética da Criação Verbal. São Paulo: Martins Fontes, 2003.

BARROS, D.L.P. Entrevista: texto e conversação. In: Anais do XXXIX Seminário do Gel, Franca, p. 254-261, 1991.

. Dialogismo, polifonia e enunciação. In: BARROS, D. L. P.; FIORIN, J. L. (orgs). Dialogismo, Polifonia, Intertextualidade. São Paulo: Edusp, 1999.

BAZERMAN, C. Gênero e identidade: cidadania na era da internet e na era do capitalismo global. In: Gêneros textuais, tipificação e interação. BAZERMAN, C; DIONÍSIO, A.P.; HOFFNAGEL, J.C. (Orgs.). São Paulo: Cortez, 2005.

BRAIT, B. O processo interacional. In: PRETI, D. (org.) Análise de textos orais. São Paulo: Humanitas, 1999. . Interação, gênero e estilo. In: PRETI, D. (org.) Interação na fala e na escrita. São Paulo: Humanitas, 2003. 
BRITO, E.V. A interação face a face na TV: a entrevista em revista. Tese de doutorado. PUC-SP, 1997.

BROWN, P.; LEVINSON, S. C. Politeness. Some universals in language use. Cambridge: Cambridge University Press, 1974.

BUENO, C.M.O. Entre-vista - espaço de construção subjetiva. Porto Alegre: EDIPUCRS, 2002.

CHARAUDEAU, P. Discurso da mídia. São Paulo: Contexto, 2006a.

. Discurso político. São Paulo: Contexto, 2006b.

; MAINGUENEAU, D. Dicionário de análise do discurso. São Paulo: Contexto, 2004.

CITELLI, A. Linguagem e persuasão. 15.ed. São Paulo: Ática, 2002.

COSERIU, E. Determinacion y entorno. In: Teoria del lenguaje y lingüística general. Madrid: Gredos, 1962, p. 282-323.

DURANTI, A.; GOODWIN, C. (eds). Rethinking context. Cambrigde: Cambridge University Press, 1992.

FÁVERO, L. L. A representação da imagem pública nas entrevistas. Linha d'Água. São Paulo: Humanitas, n. especial, p. 67-72, jan. 2000.

. Coesão e coerência. São Paulo: Ática, 2006.

; ANDRADE, M.L.C.V.O. Os processos de representação da imagem pública nas entrevistas. In: PRETI, D. Estudos de língua falada: variações e confrontos. São Paulo: Ática, 1998.

; AQUINO, Z.O. Perguntas e respostas como mecanismos de coesão e coerência no texto falado. In: CASTILHO, A. T.; BASÍLIO, M. (orgs.) Gramática do português falado. v. IV: Estudos descritivos. Campinas: Editora da Unicamp/ FAPESP, 1996.

; AQUINO, Z.O. Papéis discursivos e estratégias de polidez nas entrevistas de televisão. Revista Veredas, Juiz de Fora, v. 6, 2000. 
FECHINE, Y. Gêneros televisuais: a dinâmica dos formatos. Revista Symposium. Recife: Fasa, n. 1, p. 14-26, 2001.

FIORIN, J. L. As astúcias da enunciação - as categorias de pessoa, espaço e tempo. São Paulo: Ática, 2005.

FRASER, Bruce. Conversacional mitigation. Journal of Pragmatics, n. 4, p. 341-350, 1980.

FRASER, Bruce. Perspectives on Politeness. Journal of Pragmatics, n. 14, p. 219-236, 1990.

GALEMBECK, P. T. Preservação da face e manifestação de opiniões: um caso de jogo duplo. In: PRETI, D. (org) O discurso oral culto. São Paulo: Humanitas, 1999.

GOFFMAN, E . Relations in Public. Harmondsworth: Penguin Books, 1971. . Les rites d'interaction. Paris: Les editions de minuit, 1974. . Forms of talk. Philadelphia: University of Pennsylvania, 1981. . Frame analysis: an essay on the organization of experience Boston: Northeastern University Press, 1986.

. Footing. In: RIBEIRO, B. T. e GARCEZ, P. M. Sociolingüística Interacional. São Paulo: Loyola, 2002. . A representação do eu na vida cotidiana. São Paulo: Vozes, 2004.

GUMPERZ. J.J. Discourse strategies. Cambridge: Cambridge University, 1992.

.Convenções de contextualização. In: RIBEIRO, B. T.; GARCEZ, P. M. Sociolingüística Interacional. São Paulo: Loyola, 2002.

HALLIDAY, M.A.K. Language as social semiotic. The social interpretation of language and meaning. London: Edward Arnold, 1978.

HALLIDAY, T.L. Retórica e política: a questão da responsabilidade. In: Mídia, eleições e democracia. MATOS, H. et al. São Paulo: Scritta, 1994. 
HILGERT, J.G. O falante como o observador de suas próprias palavras: retomando aspectos metadiscursivos na construção do texto falado. In: PRETI, D. (Org.) Oralidade em diferentes discursos. São Paulo: Humanitas, 2006.

JUBRAN, C.C.A.S. Retornos e estratégias de reconstrução do texto falado. Estudos Lingüísticos XXVII. São José do Rio Preto, p. 700-704, 1998.

. A metadiscursividade como recurso textual-interativo em entrevista televisiva. In:

BARROS, K. S. M. (org.). Produção textual: interação, processamento, variação. EDUFRN, 1999.

. Marcadores metadiscursivos em entrevista televisiva: funções textuais-interativas.

In: Estudos Lingüísticos XXXI. São Paulo, cd-rom, 2002.

KATO, M. O aprendizado da leitura. São Paulo: Martins Fontes, 1990.

KERBRAT-ORECCHIONI, C. La mise en places. In: COSNIER, J. ; KERBRAT-

ORECCHIONI, C. (Eds.). Décrire la conversations. Lyon: Press Unversity de Lyon, p. 319-352, 1987. . Les Interactions Verbales. Paris: Armand Collin, t. 1, 1990. . Les Interactions Verbales. Paris: Armand Collin, t. 2, 1992. . Análise da conversação - princípios e métodos. São Paulo: Parábola, 2006.

KLEIMAN, A. Texto e leitor - aspectos cognitivos da leitura. São Paulo:_Pontes, 2004. . Oficina de leitura - teoria e prática. São Paulo:_Pontes, 2004.

KOCH, I. V. Argumentação e linguagem. São Paulo: Cortez, 1993. . A inter-ação pela linguagem. 9.ed. São Paulo: Contexto, 2004a. . Introdução à Lingüística Textual. São Paulo: Martins Fontes, 2004b. p. 3-33.

.A construção dos sentidos no discurso: uma abordagem sociocognitiva. In: Investigações: lingüística e teoria literária. v. 18, n. 1, Recife, 2006.

; ELIAS, V. M. Ler e compreender. São Paulo: Contexto, 2006.

LIMA, F. F. A metadiscursividade em entrevista televisiva e suas correlações com as estratégias argumentativas. Estudos Lingüísticos XXXV, p. 783-791, 2006. 
MACHADO, A. A televisão levada a sério. São Paulo: Senac, 2001.

MACHADO. I. Por que se ocupar dos gêneros? Revista Symposium. Recife: Fasa, n. 1, p. 05-13, 2001.

MAINGUENEAU, D. Novas tendências em análise do discurso. Campinas: Pontes, p. 75$110,1993$. . Análise de Textos de Comunicação. São Paulo: Cortez, 2001.

MALINOWSKI, B. The problem of meaning in primitive societies. In: OGDEN, C.K.; RICHARDS, I.A. (eds.) The Meaning of Meaning. London: Kegan Paul, 1923.

MARCUSCHI, L. Contextualização e explicitude na relação entre fala e escrita. Anais do I encontro sobre língua falada e ensino. Maceió, p. 27-48, 1995.

. Atividades de compreensão na interação verbal. In: PRETI, D. Estudos de língua falada: variações e confrontos. São Paulo: Ática, 1998.

. Gêneros textuais: definição e funcionalidade. In: Gêneros Textuais \& Ensino. Rio de Janeiro: Lucerna, 2002. . Análise da conversação. 5.ed. São Paulo: Ática, 2003.

MATENCIO, M. L. M. Práticas discursivas, gêneros do discurso e textualização. Estudos Lingüísticos XXXV. São Carlos, p. 138-145, 2006.

MEDINA, C.A. Entrevista - o diálogo possível. São Paulo: Ática, 1986.

MEDINA, J.B. Gêneros jornalísticos: repensando a questão. Revista Symposium. Recife: Fasa, n. 1, p. 45-55, 2001.

MIGUEL, L.F. Mito e discurso político. Unicamp: São Paulo, 2000.

MONDADA, L.; DUBOIS, D. Construção dos objetos de discurso e categorização: uma abordagem dos processos de referenciação. In: CAVALCANTE, M. M.; CIULLA, A.; RODRIGUES, B. B. (Org.). Referenciação. São Paulo: Contexto, 2003.

MOSCA, L. L. S. (Org.). Retóricas de ontem e de hoje. São Paulo: Humanitas, 2004.

OSAKABE, H. Argumentação e discurso político. São Paulo: Martins Fontes, 2002. 
OLÉRON, P. A argumentação. Lisboa: Publicações Europa-América, S/d. [Orig. PUF, 1983].

PARRET, H. Enunciação e Pragmática. Tradução Eni Orlandi et al. Campinas: Editora da Unicamp, 1988, p. 15-21.

PERELMAN, C. Retóricas. São Paulo: Martins Fontes , 1999.

; OLBRECHTS-TYTECA, L. Tratado da argumentação. A nova retórica. São

Paulo: Martins Fontes, 2002.

PRETI, D. (Org.). Análise de textos orais. São Paulo: Humanitas/FFLCH, 1993.

. (Org.). Estudos de língua falada: variações e confrontos. São Paulo: Humanitas, 1998.

. (Org.). O discurso oral culto. São Paulo: Humanitas, 1999.

. (Org.). Fala e escrita em questão. São Paulo: Humanitas, 2000.

. (Org.). Interação na fala e na escrita. São Paulo: Humanitas, 2002.

. (Org.). Léxico na língua oral e na escrita. São Paulo: Humanitas, 2003.

. (Org.). Diálogos na fala e na escrita. São Paulo: Humanitas, 2005.

. (Org.) Oralidade em diferentes discursos. São Paulo: Humanitas, 2006.

REINALDO, M.A.G.M. A interação acadêmica: elementos para a descrição do enquadramento de duas situações de fala na tarefa escolar de nível universitário. Trabalhos de Lingüística Aplicada. Campinas, n. 25, p. 61-79, 1995.

RIBEIRO, B. T.; GARCEZ, P. M. Sociolingüística Interacional. São Paulo: Loyola, 2002

RIBEIRO, B.T.; PEREIRA, M.G.D. A noção de contexto na análise do discurso. Revista Veredas. Juiz de Fora, v. 6, n. 2, p. 49-67, jul./dez. 2002.

RISSO, M. S. A propriedade auto-reflexiva do metadiscurso. In: BARROS, K. S. M. (org.). Produção textual: interação, processamento, variação. EDUFRN, 1999.

. A emergência da atividade discursiva no texto falado: sinalização metadiscursiva da busca da denominação. In: Estudos Lingüisticos XXIX. Assis, p. 103-111, 2000. 
; JUBRAN, C.C.A.S. O discurso auto-reflexivo: processamento metadiscursivo do texto. In: DELTA, v. 14, especial, p. 227-242, 1998.

; SILVA, G.M.O.; URBANO, H. Marcadores Discursivos: traços definidores. In: KOCH, I. G. V. (org.). Gramática do português falado. Campinas: Editora da Unicamp/FAPESP, v.VI, 2002.

ROSA, M. Marcadores de atenuação. São Paulo: Contexto, 1992.

SCHIFFRIN, D. Discourse Markers. Cambridge: Cambridge University Press, 1994. p. 130

SILVA, L.A. Polidez na interação professor/aluno. In: PRETI, D. (org.) Estudos de Língua Falada. São Paulo: Humanitas, 1998.

. Estruturas de participação e interação na sala de aula. In: PRETI, D. (org.) Interação na fala e na escrita. São Paulo: Humanitas, 2003.

. A língua que falamos. Português: história, variação e discurso. São Paulo: Globo, 2005.

SILVEIRA, S. B. Reclamações e movimentos corretivos: um estudo de caso. Revista Veredas, Juiz de Fora, v. 4, 1999.

SETTEKORN, W. Pragmatique et rhéthorique discoursive. Journal of Pragmatics 1, North-Holland Publishing Company, 1977.

TANNEN, D.; WALLAT, C. Enquadres interativos e esquemas de conhecimento em interação. Exemplos de um exame/consulta médica. In: RIBEIRO, B. T. e GARCEZ, P. M. Sociolingüística Interacional. São Paulo: Loyola, 2002.

TAVARES, O. Fernando Collor - O discurso messiânico - O clamor ao sagrado. São Paulo: Annablume, 1998.

VAN DIJK, T. A. Cognição, discurso e interação. 6. ed. São Paulo: Contexto, 2004. . Discurso, notícia e ideologia. Porto: Campo das Letras, 2005.

- Discourse, context and cognition. Disponível em: http://www. discourses.org/teun.html. Acesso em 03 jul. 2006. 
. Discourse, ideology and context. Disponível em: http://www. discourses.org/teun.html. Acesso em 03 jul. 2006.

. Macro contexts. Disponível em: http://www. discourses.org/teun.html. Acesso em 03 jul. 2006. 
ANEXO 1

TRANSCRIÇÃO 
O programa transmitido ao vivo em agosto de 1998, pelo Sistema Brasileiro de Televisão - SBT, com duração de uma hora, apresentou-se em 2 blocos separados por intervalo comercial, como apontamos na transcrição a seguir.

Os locutores são identificados, em nossa transcrição, como L enumerados de acordo com a ordem de apresentação do programa. Assim, para localizarmos os locutores, identificamos como locutor 1 (L1) os enunciados do mediador Sérgio Groisman e como locutor 2 (L2) os enunciados de Fernando Collor.

Ao todo, são dezessete os jovens entrevistadores identificados como locutores L3, L4, L5, L6, L7, L8, L9, L10, L11, L12, L13, L14, L15, L16 e L17. 
L1 MAIS SOM ... ((aplausos)) mais mais mais mais mais mais mais... ((aplausos)) e boa tarde garoto boa tarde garota agora mais UM::.... PROGRAMA LIVRE... Programa Livre hoje especialíssimo... vai receber o ex-presidente Fernando Collor de Melo ao VIVO... com a gente aqui... colégios Equipe... Bandeirantes... Logus... Arquidiocesano... pessoal de Americana... Argos de Santo André... Anglo Vestibulares...portanto...no próximo bloco... ao vivo...o presidente expresidente Fernando Collor de:: Melo... Programa Livre dá um tempo e volta JÁ

10 L1 muito bem... voltando ao vivo aqui...SBT... Programa Livre...o expresidente Fernando Collor de Melo já está se dirigindo aqui... para os nossos estúdios... onde... em três minutos... sentará aqui... ((aponta para o assento destinado ao entrevistado)) pra conversar com a gente aqui... a respeito das perguntas que serão feitas pelos 15 adolescentes...representando...a juventude brasileira aqui...hoje...no Programa Livre...pra gente ganhar tempo e ter 2 blocos bem grandes... sem intervalo... a gente vai pra mais um... em.:. três minutos... a gente voltaVOLTA 
L1 muito bem...voltando ao vivo aqui pelo SBT Programa Livre... que recebe agora... o ex-presidente Fernando Collor de Melo ((entrada de Collor e vaias do auditório)) boa tarde... muito obrigado pela vinda... ao:: Programa Livre

L2 eu é que agradeço o convite que você me fez e é com muita alegria que estou aqui em seu programa

25 L1 muito obrigado e a partir de agora... vamos começar as perguntas... ao ex-presidente Fernando Collor de Melo... que está no Brasil efetivamente há quanto tempo? sei que tem uma ponte aérea aí mas...éh éh essa última vez tá quanto tempo aqui direto?

L2: não...já estou de volta ao Brasil des::de... fevereiro/final de fevereiro começo de março...

L1 agora vai ficar?

L2 e vou ficar aqui já estou de volta ao Brasil

L1: ta ok vamos começar as perguntas ah:: primeira garoto fala

L3: Rodrigo do Colégio Arbes... o senhor acredita que foi julgado e condenado por que estava num partido de menor poder político? assim... se o Sr. estivesse num PMDB ou num PFL se não... não seria condenado... no impeachment?

L2: não sem dúvida se eu tivesse maioria no Congresso Nacional... jamais... teria acontecido o chamado impeachment... e isso não foi dito por mim quer dizer isso foi dito pelos líderes inclusive da oposição... ah::: no fundo o que nós percebemos é que na eleição de $1989 \ldots$ ela foi uma eleição solteira... ou seja foi eleito apenas o Presidente da República não houve eleição para deputado e para senador... de modo que quando eu tomei posse em março de $90 \ldots$ o Congresso... com o qual eu comecei a governar era o Congresso eleito em 1986... portanto... eleito esse Congresso num moMENto diferente da minha eleição seis meses depois da minha posse... houve a renovação desse congresso... que também foi eleito num moMENto diferente... daquele que elegeu o presidente em 89 essa eleição de 98 é uma eleição diferente porque é uma eleição casada... ou seja... quando a gente vai votar no presidente que a gente quiser... a gente é levado a votar... nos candidatos a deputados e senador... que estejam identificados com esse presidente... e isso constitui-se então a chamada base parlamentar... eu não tinha base parlamentar... o meu partido era pequeno... e continua sendo pequeno... se eu tivesse maioria no congresso nacional... nada disso teria acontecido.

L1: ok quem mais? ...tá com o microfone aí? não... então pergunte depois ce passa pra ele

L4: é::... diante de uma possível candidatura nessas eleições... como o senhor pretende i/éh:: se apresentar diante do povo que uma vez te elegeu e depois te depôs... e quais são as suas propostas?

L2: veja que... eu me apresento hoje diante...diante de todos vocês... tendo sido... o homem público... mais investigado desse país... o mais 
humilhado o mais xingado o mais achincalhado o mais execrado... e seguramente o mais investigado... o último homem público que sofreu alguma coisa parecida... em termos de:: de::... investigação... foi o doutor Getúlio Vargas... em 1950... e que lamentavelmente não suporTOU... aquela pressão e deu fim a sua própria vida... então hoje eu me apresento... tendo sido... como disse... investigado de cima a baixo... quer dizer foram 2 anos de/e meio de investigação... em que investigaram... TOda a minha vida... e todo o resultado dessa investigação foi levado a consideração da mais alta corte de justiça do país... que me considerou inocente daquelas acusações... e eu me pergunto se hoje... há um homem... bom se nós se nós estamos vivendo num estado democrático de direito... e se nós acreditamos... que à justiça cabe julgar as denúncias que são feitas... e não ao... ao nosso interesse partidário... então nós temos que reconhecer que esse é o canal legítimo... que nós podemos recorrer dentro de uma democracia... para sabermos quem está com a razão... e a mais alta corte de justiça do país... me declarou inoCENte dessas acusações eu não sei se houve um homem público brasileiro... hoje... submetido às mesmas investigações a que eu fui submetido... se eles poderiam apresentar ao final dessas investigações... esse atestado... que me foi dado pela mais alta corte de jusTIça do país... de inoCENte daquelas acusações... fui julgado pelos políticos... fui e fui condenado... fui julgado pela justiça e fui absolvido... e o que eu desejo agora... é nada mais nada menos... que seja dado o diREIto ao eleitor de fazer esse julgamento... sem intermediários... que votem contra mim ou a favor de mim... mas o eleitor... representando a sua consciência representando o seu desejo representando as suas expectativas... e não que... meia dúzia de gatos pingados... lá no Congresso Nacional... se arvorem no direito de em nome de 35 milhões de eleitores... de fazerem o que fizeram... vocês todos se lembram que quem comandou... esse processo contra mim... foi o então presidente da câmara dos deputados... chamado Ibsen Pinheiro... que três ou quatro meses após aH é:: eles terem me arrancado da presidência... eles mostraram a sua verdadeira face... Eles... os anões do orçamento... eles sim... estavam assaltando o tesouro nacional... eles sim... estavam fazendo as ...é as diabruras e travessuras que todos nós conhecemos... e se eles me arrancaram da presidência... é porque minha gente... seguramente eu não era um deles... e não estava fazendo o jogo deles

100 L1: agora....é ...quando quando ((aplausos)) quando o senhor fala ((pausa prolongada)) quando o senhor fala quatro ou cinco gatos pingados... o senhor tá se referindo a maioria do Congresso naquele momento... TAMBÉM eleito pelo povo assim como o senhor

L2: $\quad$ sem dúvida sem dúvida/me refiro/quer dizer é uma força de expressão... eu me refiro ah:: ao Congresso Nacional comandado... por este que eu já falei o nome... e que em nome de 35 milhões... né?... tomaram aquela atitude sem terem autoridade moral para isso porque ele que comandou tudo ele que atropelou todo o processo... porque minha gente vocês talvez não tenham... parado um pouco pra acompanhar todo esse processo foi uma... foi uma... do ponto de vista jurídico né?... foi uma violência atrás de outra porque não me foi dado direito de defesa em nenhum instante não me foi dado ah: oportunidade de poder falar... dentro ((risada)) dentro do processo... de modo que as coisas foram acontecendo assim de uma forma ah:... violenta... e ah: ah ah inclusive... 
afetando a própria constituição né?... de modo que:: o que eu desejo nesse momento é de colocar o meu nome ao julgamento popular é só isso

L1: quem? quem? quem? quem? quem? quem?

L(?) (incompreensível)

120

L5: é::: o senhor acredita no dito popular que o brasileiro não tem memória... por isso o senhor está ree/candidatando... a propósito o senhor tem memória? ((gritos e aplausos))

L2: não o povo o povo o povo brasileiro o povo brasileiro tem memória o povo brasileiro tem memória... o que... o que o povo brasileiro está fazendo né? deste período para cá... é fazendo o seu verdadeiro juízo... porque eu digo pra vocês minha gente eu já tive a idade de vocês... não é eu já estive em colégios secundários eu era líder estudantil era líder é::... na universidade... na época do golpe militar né? eu levei muita pancada... fui preso duas vezes... de modo que eu se tivesse na posição de vocês naquela oportunidade com aquela campanha da mídia eu seguradamente estaria também na ruas pedindo a deposição do presidente que fosse... então eu eu entendo perfeitamente tudo que se passou e entendo... a mobilização que foi feita com os jovens porque eu também já fui mobilizado... então ah: de modo que eu acredito que o povo brasileiro sim tenha memória... eu tenho memória por exemplo memória... exata de tudo o que aconteceu... desde que eu comecei di a::: na::: minha faixa dos quatorze quinze dezesseis anos... a participar de alguma forma da vida política do meu país... e eu tenho a memória muito grande de tudo o que aconteceu... agora acontece que ao longo do tempo a gente vai fazendo o nosso juízo... porque muitas coisas que dizem... quantas vezes a gente não /uma pessoa não chega pra gente e diz assim... é ó não fala com esse camarada não porque ele não presta porque ele é um chato... e daqui a pouco a gente vai falar com a pessoa e descobre que é completamente diferente daquilo que nos disseram... o que é importante o que é importante é que seja dado oportunidade... ao povo brasileiro de fazer o seu juízo dentro de um ambiente de razoável tranqüilidade... sem que haja um clima de emoção... transbordando pelas ruas... de modo a dizer... esse fulano aqui é é culpado... temos que crucificá-lo ele é o causador de tudo e tal... nós temos que ter uma ponto de razão... e pra isso é preciso que tenhamos memória... e o povo brasileiro TEM memória

150 L1: ok...em cima garoto... garoto fala

L6: é...eu queria saber ...depois de... depois de tudo que o senhor foi acusado... o que você acha da miséria assim que está no Brasil... na:: em questão à seca... do nordeste assim... e o que o senhor acha do plano do Fernando Henrique?

155 L2: bom nós tamos viven::do... um momento... de extrema gravidade no país não é... todos nós sentimos nas nossas casa vocês sentem nas suas as dificuldades por que passa o país... nós temos hoje alguma coisa que a sociedade conquistou que é positiva... que é chamada a estabilidade monetária... mas acontece que essa estabilidade monetária... está 160 sen::do... mantida a custa de um enorme sacrifício... nós temos hoje desemprego recorde no país... a saúde nunca esteve numa situação de calamidade como hoje se encontra... e nós nos lembramos que nos foi 
pedido o imposto do cheque... o chamado CPMF dizendo me dêem o CPMF que eu salvarei a saúde... o CPMF recolhe de seis a sete bilhões por ano... e desses recursos quase NAda vai para a saúde vocês aí alguns alguns são universitário né?... e sabem que hoje a universidade está relegada... a um plano secundário... quando a universidade num num mundo globalizado como está... tem que se a fonte de cérebros e de mãode-obra extremamente qualificada... para ajudar o país a competir nesse mundo globalizado... nós temos aí os aposentados sendo tratados com adjetivos e:: de forma pejorativa... nós temos aí o/ah:: os funcionários públicos que estão há quatro anos sem reajuste... nós temos aí os comerciantes... os empresários os industriais que estão quebrando estão falindo... por culpa desses juros extorsivamente altos que estão impedindo o país de progredir... enfim... e nós vemos aí esses efeitos todos causados pe/pe/pela po:lítica econômica e ficamos todos muito preocupados a crise que se abate sobre o país é séria o organismo econômico brasileiro está debilitado... e... portanto qualquer vírus que venha lá de fora seja da Ásia se/seja da Rússia vai pegara esse organismo debilitado... e pode sub/submeter a esse organismo a um processo duríssimo... de uma doença de difícil recuperação... por isso é que eu acredito que é necessário nós fazermos mudanças profundas... mantendo a estabilidade mas com desenvolvimento

L1: $\quad$ agora...é...na hipótese... do senhor (poder) se candidatar poder se candidatar através do TSE e numa hipótese... de um segundo turno ah::é::exsistir o que existe hoje uma::... uma::... uma briga bem forte entre Lula e Fernando Henrique... no segundo turno... em quem o senhor votaria?

L2: $\quad$ eu votaria no Lula

190 L1: no Lula... por que... por que essa mudança tão grande?

L2: $\quad$ porque... o Lula e outro dia num programa de rádio... outro dia num programa de rádio... outro dia emBOra eu ache que num segundo turno estaremos novamente eu e Lula... mas num ((gritos da platéia)) num programa ((gritos da platéia)) me permitam dizer isso ((gritos da platéia)) bom ((silêncio)) mas deixa eu dizer... deixa/deixa eu dizer... então eu estava num...num programa... num programa de rádio num debate... e me perguntaram alguma coisa sobre o:.... eleição e sobre:: o Lula ...e tal e eu me referi ao Lula como o companheiro Lula... e havia dentre os jornalistas dois que eram do PT... e eles intrigados com aquilo de companheiro companheiro aí ele me pergunta... mas pera aí... como chamá-lo de companheiro... ele não é seu companheiro... aí eu disse engano seu... nós fomos companheiros no:: na campanha das diretas... nós fomos companheiros na disputa pela presidência em $89 \ldots$ e hoje somos companheiros na mesma visão crítica que TEmos... do governo FHC... então não posso /posso dei/ é:: é:: deixar de dizer que eu me considero HOje... e nessas circunstâncias um companheiro... e falo...e falo que num segundo turno embora eu acredite... segura e sinceramente... que num segundo turno estaremos Lula e eu novamente reedidanto... a final de $89 . .$. se houver... se houver se...não der isso... e se der Fernando Henrique e Lula... eu votarei em Lula para presidente

L1: $\quad$ aqui ah 
L7: é:: o senhor acha que o que aconteceu com PC Farias foi queima de arquivo?

L2: $\quad$ não sei se foi queima de arquivo ou se... o que houve exatamente... eu devo me valer... do relatório da polícia... que foi muito investigado né? vários investigadores substituíram vários investigadores até chegarem a conclusão... de que foi um clima um crime passional né? ...então eu tenho que me valer pelo laudo que a polícia divulgou e tornou oficial.

L8: alô... senhor presidente eu queria saber ah... porque o senhor se declara totalmente inocente né? e... que foi na verdade posto num esquema

L2: não ninguém ninguém é santo... eu não sou santo eu cometi erros

L8:

o senhor expôs mas da maneira

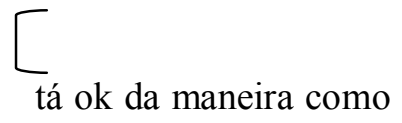<smiles>C1CCCC1</smiles>

L2: $\quad$ claro... claro que eu cometi erros agora... não só um minutinho... agora... agora... agora nenhum nenhum... nenhuma dessas... acusações graves que me fizeram elas foram verdadeiras... porque se fossem verdadeiras eles teriam vocês não acham que eles teriam me condenado claro que teriam... na/nada disso tanto que não foi porque foram dois anos e e meio de investigações ta certo... desculpe a interrupção

230 L8: com certeza o senhor fala que... foi investigado sua inva/éh:: sua privacidade foi invadida e tal... só que a maioria dos brasileiros não...o consideram inocente eu queria saber como o senhor lidá com isso de... legalmente sendo inocente mas... é... moralmente eu acho que não é por aí ...entendeu ((aplausos e gritos))

235 L2: veja...((gritos do auditório)) veja... ((gritos do auditório)) veja... ((gritos do auditório)) é pra isso é pra isso que existe uma eleição... entende é pra isso que existe uma eleição ah:: e é pra isso que eu desejo ouvir... a resposta popular nas urnas... quer dizer você fala e com toda... e com toda a propriedade que o :: que o seu entendimento... ah:: merece... de que esse não é seu entendimento... mas vamos vamos ouvir... o conjunto da população... e é exatamente essa resposta que eu estou buscando... eu estou buscando... nas URNAS a resposta da população brasileira... a essa dúvida que alguns segmentos ainda têm... e eu desejo democraticamente submetendo o meu nome a julgamento popular... ter esse julgamento popular... nas eleições de 98

L9: senhor senhor ex-presidente eu queria saber do senhor... sem muita auto propaganda... se:: o senhor dorme tranqüilo sabendo mesmo sabendo que:: cento e cinqüenta milhões de pessoas te odeiam? ((gritos e aplausos da platéia))

250 L2: não não exagera ((gritos da platéia)) ((risadas)) não exagera não exagera cento e cinqüenta milhões não até porque... no/ nós temos que... ((barulho e risada de L2)) veja bem... não é... e é por isso é ser isso que eu desejo... eu:: eu repito né? é por isso que eu desejo submeter o meu nome a julgamento popular porque eu desejo saber... realmente... qual é 
o julgamento popular... sobre o meu período como Presidente da República e sobre as expectativas que eu posso despertar ainda no seio da população em relação ao nosso futuro... é essa a resposta que eu busco

L1: $\quad$ cadê....aqui aqui aqui

L10: gostaria de saber a sua opinião... sobre a grave cri::se:: social que o país 260 está enfrentando no governo Fernando Henrique... inclusive o desemprego que é assustador um milhão e seiscentos mil de desempregados só na grande São Paulo?

L2: éh o desemprego o desemprego o desemprego minha gente realmente é... é... enorme... é gritante nunca um país ah é::ah:: encarou enfrentou um problema social como este... e na / no o desemprego é causado... basicamente por uma política econômica que está em curso... há um desemprego inicial... nesse mundo chamado globalizado... que é causado pela globalização... os países ricos e desenvolvidos por exemplo... ele tem desempregados... e quem são esses desempregados? os desempregados dos países ricos e desenvolvidos são aqueles trabalhadores que... extremamente qualificados... recebem um salário... compatível com essa qualificação... por exemplo... um programador de software na Alemanha que ganhava dez mil dólares por mês... foi... está sendo despedido no início do processo de globalização... substituído o seu trabalho por alguém que na índia Bangladesh por exemplo faz aquele mesmo tipo de serviço por mil dólares... então o desemprego no início do processo da globalização... num mundo desenvolvido e rico... afetou mão-de-obra extremamente qualificada... e com remuneração compatível com essa qualificação da sua mão-de-obra... nos países chamados emergentes nas economias emergentes como o Brasil... o desemprego pegou inicialmente quem?... exatamente o trabalhador com sinal oposto... o trabalhador desqualificado que nem...nem com um processo de reciclagem conseguiu estar apto para enfrentar essa competitividade no/no mercado... e que recebia um baixo salário... então vocês vejam que lá os órfãos os órgãos da chamada globalização... lá no mundo desenvolvido são funcionários qualificados no mundo em desenvolvimento são funcionários... sub-qualificados então esse é um desemprego que a gente entendo que tem sido causado pela globalização o excesso de desemprego... quer dizer esse/essa margem é ah...ah enorme a mais de desemprego no Brasil... vem sendo causada pela política econômica... pela política monetária e política cambial o que significa isso taxa de juros extremamente elevada... e uma moeda supervalorizada que retira... lá... dos nossos produtos... da competição externa pela supervalorização ou sobrevalorização... do chamado real... então o que nós precisamos é de aprofundar as reformas andar com as reformas por exemplo tributária fiscal para evitar que essas duas âncoras ah:: a monetária e a cambial proporcionem isso que nós estamos assistindo hoje... que não é somente o desemprego... mas é uma crise social sem precedentes aqui em São Paulo a cada vez que volto a São Paulo... eu encontro mais relatos e mais pessoas é dizendo sobre a insegurança que vivem aqui na capital... dos assaltos que são feito enfim desse/desse clima quase de estado de sítio em que:: está vivendo as grandes metrópoles das quais São Paulo sem dúvida é a mais importante

L11: oi eu queria saber como você responde hoje as acusações que foram 
L2: $\quad$ sobre o uso de drogas? ((aplausos e gritos do auditório)) olha ((risada)) isso aí ((risada)) isso aí já....já foi tão...tão dito e tão... e tão repetido não é? eu quero dizer a vocês que... eu quero dizer a vocês que... ah:: todas essas acusações... também são acusações falsas... vocês sabem... vocês sabem... vocês sabem... conhecem a minha vida... não é... conhecem a minha vida que foi muito bem é:: explorada pela imprensa e muito bem dita... eu sempre fui uma pessoa dedicada a uma vida exTREmamente saudável... sempre fui... sempre fui... desportista... não é?... sempre pratiquei os meus esportes a vida ao ar livre e... nas vezes que eu posso falar com pessoas como vocês eu sei que vocês gostam também muito de esportes eu digo olha minha gente... vão pro esporte vão pra fazer uma atividade física deixa essa coisa de droga de lado porque não leva... ninguém a nenhum lado... então eu quero é exaltar é exaltar a saúde... a condição e o condicionamento físico... como uma maneira que nós temos de administrar BEM... aquilo que Deus nos deu que foi o nosso corpo... se nós não administrarmos BEM... o nosso corpo cuidando da nossa saúde... nós não saber/ saberemos administrar nada na nossa vida.

L12: é:: eu quero saber se::::assim/se:: quer se submeter a um julgamento popular agora né?... então eu quero saber se você não acha... que:: o seu poder de persuasão é maior que a capacidade de discernimento do povo... que não tem cultura... e não tem e...ducação necessária pra/e é facilmente manipulado? ((gritos e aplausos do auditório))

L2: veja que:: ((gritos do auditório)) você me atribui um poder de persuasão que eu não sei se tenho... o que eu sei que tenho

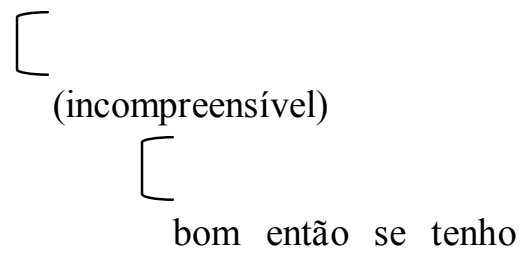
obrigado ((risada do locutor e aplausos do auditório)) agora... agora... agora pessoal... o que eu sei que tenho é o seguinte... é o que muitos de vocês têm... eu não sei fazer nada na minha vida que não seja com paixão... com ardor e ((risos e gritos do auditório)) com vontade ((risos e gritos do auditório)) não não a paixão piegas ((risos)) não... não... cês estão entendendo... não é essa paixão não é essa paixão piegas paixão piegas é uma paixão no sentido de me dedicar inTEgralmente àquilo que eu tô fazendo... então... então... às vezes... às vezes... vocês é como ela entende a persuasão... ah:: talvez seja a vontade que eu tenho de transmitir a Minha verdade cada um tem a sua verdade... e eu GOSto de transmitir a minha verdade com a absoluta sinceridade... e com e com absoluta convicção daquilo que estou dizendo... e não sou somente eu... eu acredito que todos aqueles que... estejam numa posição de:: homem público... colocando seu nome ao julgamento popular... eles têm não somente o direito mas o deVER de passar a sua verdade... e deixe que população... o povo eu sempre digo... o povo pode ser inculto... mas não é burro... o povo é muito mais sábio do que nós podemos imaginar... e o povo é o que nós temos sempre que ver minha gente... as grandes transformações sociais... as grandes transformações sociais as grandes mudanças históricas ocorridas no mundo em qualquer época que se considere... teve a decisiva participação popular... então o povo 
L2:

bom mas se você disser que foi manipulada você também pode ah:::ah::dizer que ah::ah:: aqueles que saíram às ruas de cara pintada contra mim foram manipulados e::

$\mathrm{L}(?)$ :

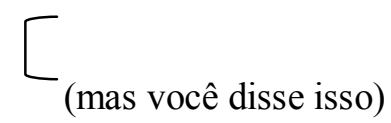

L2: eu não acredito que dizer ((gritos do auditório)) não ((gritos do auditório)) a manipulação... minha gente a manipulação ela a manipulação ela pode existir existir mas em determinado momento em relação a um a um determinado segmento... a manipulação não é geral... é impossível haver uma ma-ni-pu-la-ção global minha gente

L1: ok no próximo bloco a gente continua... programa livre dá um tempo volTA JÁ 
365 L1: beLEza voltando ao vivo... aqui... no SBT Programa Livre com o expresidente Fernando Collor de Melo... garoto fala

L13: já que tava falando de manipulação... eu queria saber se... você não acha que se não tivesse sido tão ajudado pela Rede Globo... principalmente no seu último debate com o Lula que foi editado para ser passado no Jornal 370 Nacional se o senhor teria ganhado as eleições? ((gritos e aplausos do auditório))

L2: olhe... é preciso a gente... voltar um pouco atrás não é e:: para ver como foi:: como se realizou a eleição em $1989 \ldots$ em $1989 \ldots$ eu era... um candidato... considerado azarão... por quê? porque eram as primeiras eleições democráticas depois de quase trinta anos de jejum de abstinência eleitoral não é... depois do golpe de 64 nós ficamos quase trinta anos sem eleição para presidente... e então em 89 ... qual era ah:: o que se discutia né?... com tantos nomes... pesos pesados da política nacional... havia aí já falamos do do Lula... do Ulisses Guimarães o Mario Covas o Paulo Maluf o Guilherme Hadib Domingues o... Leonel Brizola enfim... e havia um um candidato a presidente... que::: tinha saído do governo de Alagoas com um partido inexpressivo... do ponto de vista do:: de conhecimento:: da população e de capilaridade ou seja de representação dos municípios brasileiros... então naturalmente não é nem porque a imprensa não quisesse... é a:: à minha candidatura não há não era dada nenhuma importância porque achavam que era uma brincadeira... então no primeiro turno da eleição o que nós assistimos... foi exatamente isso... a grande mídia dando um cobertura ah::: aos::: candidatos... e naturalmente àqueles que eram conhecidos até porque eu acho que a população queria saber mais... dos candidatos que elas que ela população conhecia melhor não é?... no segundo turno foi diferente... porque no segundo turno como vocês sabem... é plebiscito... é::: azul e vermelho é branco e preto não é? não tem não tem meio termo o segundo turno turno é::: foge inteiramente à racionalidade da eleição...muita gente chegou $\mathrm{e}$ disse assim não eu votei eu votei no Collor porque:::eu não queria o Lula... não eu votei... no Collor porque::: eu achei que:: o Lula ia fazer alguma coisa de comunismo no país... essas coisas bobas... não é::: esses raciocínios bobos não é::: mas que naturalmente não significam que se votou naquele candidato escolhido porque gostaria de votar nele... então ah::ah:: no segundo turno.. ah o que houve foi um posicionamento... dos diversos órgãos de comunicação em relação a uma candidatura ou a outra eu não eu-não concordo na questão da manipulação o que dizem que a Rede Globo fez em relação ao debate porque o debate foi transmitido ao vivo para todo o Brasil... em cadeia 405 nacional de rádio e televisão... então foi um dos programas... foi esse horário um dos mais ouvidos não é... um dos maiores ibopes havido naquele tempo foi exatamente o debate final... entre Lula... e eu na disputa pelo segundo turno... então é difícil haver manipulação quando a transmissão é ao vivo... que manipulação pode haver?... nenhuma manipulação eu acredito que o o::: o fundamentalmente o que::: o que houve... o que houve... o que houve do mesmo modo que no primeiro debate eu não fui bem... no segundo debate eu acho que fui melhor que o Lula... então o que ficou foi a impressão do último debate

L13: mas a edição que eu estou falando é::um resumo que foi feito pra ser passado no Jornal Nacional... eles fizeram um resumo de seis minutos... 
que passou::: praticamente :: um minuto a mais do senhor falando que o Collor/que o Lula

L2: $\quad$ bom isso aí eu não não imaginei não peguei não sei ((vais do auditório)) mas fundamentalmente o que houve foi isso quer dizer o debate passou ao vivo... o debate passou ao vivo

L14: primeiro eu queria dizer que eu tenho esperança de que você não vá para o segundo turno... e depois eu queria saber que:: você gostando tanto da natureza por que o senhor não fez nada pelo meio ambiente e:::

L2:

pera aí não ((risos))

nossa senhora<smiles>CCC</smiles>

L14:: $\quad$ e não e que você pode fazer mesmo sem ser presidente da república você não precisa disso<smiles>CCC</smiles>

L2: $\quad$ sei mas pera aí pera aí pessoal assim também não ((risos e aplausos)) nossa senhora em relação a

(incompreensível)

L2: em relação a questão ambiental a questão ambiental o que o avanço que o Brasil deu na minha administração olha... não é não é não sou eu que tou dizendo... não sou eu minha gente que tou dizendo... isso aí são os próprios organismo internacionais não é::.... no que diz respeito respeito à política indígena... no que diz respeito respeito à política indígena... à política ambiental o Brasil deu um passo giGANtesco nós realizamos aqui em 1992... a maior conferência que é/ah:: tomando-se em consideração para dizer se é a maior... o números de chefes de estado e chefes de governo presentes nessa reunião... foram $158 \ldots$ chefes de governo e chefes de estado e estivemos reunidos durante quinze dias... lá... no Rio de Janeiro tratando exatamente de avanços com propostas ambientais para salvar o nosso planeta... nós assinamos tratados da maior importância essa conferência do Rio sobre meio ambiente e desenvolvimento é considerado um marco... um marco histórico pela/na 445 luta ambiental... na questão indígena... não sei se vocês se lembram... mas nós conseguimos salvar os ianomani... os iannomani estavam sendo dizimados pela ação... dos homens brancos... e por ação de uma poLÍtica indigienista que o/os levaria certamente à extinção... e nós fizemos uma reserva de oito:: milhões de hectares na Amazônia... exatamente para preservar uma das culturas mais antigas de que se tem notícia nas nossas Américas... ah:: na questão do... na questão da do nosso dia-a-dia eu fiz incluir no currículo escolar ah:: uma disciplina de educação ambiental para que desde a mais a/a a criança né? a mais tenra idade pudesse tomar conhecimento da importância que tem a nossa natureza... não enfim... eu acho que:: em relação à questão ambiental nós demos um passo MUIto grande e/eu quero até lembrar a vocês um episódio... ah:: eu gostava muito e continuo gostando hoje talvez um pouco menos mas eu gosto de velocidade eu gosto de esportes perigosos... e eu fazia... eu fazia jet ski... e uma vez o Jacques Costeau o Jacques Costeau é:: o comandante 
((tossiu)) Jacques Costeau... ((tossiu)) que faleceu recentemente... no ano passado ele chegou pra mim e disse assim ((tossiu)) eu queria lhe fazer um pedido ((pausa prolongada)) que você parasse de andar de jet ski... eu disse mas por quê comandante... e ele disse o jet ski em geral em geral isso eu queira passar para vocês o jet ski em geral... é utilizado utilizado sempre naquela área ah::: perto da... arrebentação... ou seja... perto da areia em se tratando de mar... e é ali... naquela região naquela zona em que os alevinos que são os os as ovas dos peixes... vão buscar ah:: o calor necessário para a sua correta... reprodução e desenvolvimento... e o jet ski passando ali naquela região... ele mata e aniquila bilhões e bilhões e bilhões de alevinos... então ele disse eu queria lhe pedir que não não usasse mais o jet ski porque isso pode causar as pessoa podem querer achar que isso é bom e vão querer fazer a mesma coisa... e isso é ah:: afeta e causa um enorme dano à natureza... desde esse dia eu parei de ujar/usar de usar o jet ski e queria também deixar isso com vocês se vocês gostam de jet ski que usem... que usem fora fora dessa região ((gritos e aplausos do público))

L1: fala fala garoto

L15: senhor presidente... eu queria::: bem/ você pelo jeito que tá... criticando o Fernan/Fernando Henrique você deve... querer algumas mudanças né?... e eu gostaria de saber como você pretende fazer isso... partindo de uma família oligárquica do nordeste... e com apoio de:: grandes interesses lá que:: é mais do que sabido... que eles mantém a miséria daquela população... para que elas não tenham educação... entendeu... e pra dar o voto... os chamados currais eleitoreiros né?... pra como... currais eleitorais... entendeu? que usam esse voto entendeu dessa população miserável que não tem educação... entende?... e aí pode... pode... de repente eu não sei se é o caso do senhor... mas é o que me parece apoiar um certo candidato e esse candidato acaba vencendo... eu quero saber... e qual é a bancada ruralista né?... que é uma bancada ruralista né? que:: vende votos né?... que é um absurdo... o Fernando Henrique tá tendo que ah::ah:: aprovar algumas coisas ta tendo que::... gastar não sei quanto em cada votação... eu quero saber VOCÊ entende? partindo dessa base eleitoral que é o nordeste... como é que você pensando em fazer algumas mudanças e:: com esses interesses... só pra complementar ((entrega o microfone a L16))

L16: ó... você falou aqui... que:..... ó... algumas é... incoerências aqui no seu discurso tá... você falou da equipe econômica do Fernando Henrique mas muitos membros da equipe econômica do Fernando Henrique foram... membros da sua e/equipe econômica como o Candir tá... o:: o... Renan Calheiros que é o ministro da:: da:: justiça que... cê acabou de citar como... que você... não foi é::: culpado pela justiça não sei o que foi é :: teu colega de Alagoas é ministro da:: da justiça lá... você também falou do congresso nacional... só que no segundo turno da eleição... é::: a grande maioria do congresso... foi a favor seu... principalmente o PFL ou na época o PDS né? toda a bancada deles eram a seu favor... e você tinha maioria do congresso no começo do governo... e outra coisa... você falou que... por falta talvez de memória nossa aqui... você era um considerado um azarão na campanha de $89 . .$. mas desde da convenção do PMDB por exemplo:: você já... já estava em primeiro lugar na... na eleição na pesquisa com que... pra/ explicar que a convenção do PMDB foi feita na mesma época que/que tamos hoje aqui pra eleição mais ou menos... você 
já era já era o primeiro lugar empatando com o Quércia né? na::: época na época daí elegeram o Ulisses Guimarães na convenção então você não era você não foi um azarão você falou que no no segundo turno as pessoas não votaram em você... porque::você tava ah:: é ...não:: ia:: é:: votar votavam em você porque não iam votar no Lula... só que desde o primeiro turno você já tinha quarenta porcento dos votos... tá e agora eu vou fazer uma pergunta pra você ((risos de Collor e aplausos do auditório)) ó tendo em vista a guerra civil colombiana que podemos presenciar neste momento ((gritos do auditório)) eu quero dizer que... a guerra civil foi provocada na:: Colômbia... porque em 1958 pela aliança do::: partido conservador e o partido liberal que são... o equivalente no Brasil aos partidos conservadores da elite... burguesa... que governam o nosso país... eles chegaram a um acordo... e:: começaram a governar o país... pó/por democracia democraticamente e::.:: esse acordo fez surgir a sombra... a sombra desse governo... o as guerrilhas colombianas tipo FARCS e:: Exército de Libertação e etc e essas guerrilhas hoje comandam... é:: quarenta porcento do país junto com os grupos paramilitares lançados pelo... pela aristocracia rural e pelo governo norteamericano... aí eu que/queria fa/falar eu queria que você ((gritos do auditório)) respondesse pra mim... eu queria se você não tem medo que /com a elite contínua no governo Brasil democrática com essa falsa democracia que governa hoje... o:::: movimento sem terra se armar por exemplo... como se armaram os exércitos... de libertação da Colômbia se armarem... e provocar uma guerra civil no Brasil ((aplausos e gritos))

L2: eu continuo... eu continuo acreditando eu vou tentar... eu vou ver se me... me lembrarei lembrarei... das das perguntas que foram feitas ((gritos)) e se faltar alguma por favor vocês me lembrem bom vamos começar pela última aí que me parece... a mais... a mais importante... e ah:: conjunturalmente mais ((pausa prolongada)) qual foi mesmo? ((gritos)) ah das oligarquias então vamos começar pela dele... ah:: a minha família... não é uma família que é:: a gente pode chamar de oligárquica

?:

L2: 545

L?:

L2:<smiles>C1CCCC1</smiles>

(incompreensível)

sim pera aí mas lá existem... veja bem... no/nós somos nós somos a nossa família... é uma família basicamente de jornalistas... era jornalista meu bisavô meu avô meu pai e nós nós<smiles>C1=CCCC1</smiles>

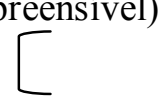

uma agressão desnecessária... bom e... e eu também entende... então também... então nós sempre nos dedicamos ao jornalismo sempre nos dedicamos ao jornalismo ah:: e temos lá empresas de comunicação... há muitos e muitos e muitos anos... e não temos... não somos proprietários rurais nunca criamos ou plantamos nada... nos dedicamos única e exclusivamente à família ao nosso negócio ao nosso ao nosso trabalho que é a de comunicação... com televisão com rádio com jornal e com gráfica e editora... bom... então é isso então não pertencemos à 
oligarquia... na questão de da candidatura minha ao governo do estado... foi uma candidatura... em que se rompeu pela primeira vez os chamados currais eleitorais... a campanha eleitoral em 1986 a o:: governo de Alagoas foi uma campanha de uma violência brutal... que a gente só vê talvez em filme e mesmo assim não acredita... por quê? porque eu me insurgi exatamente contra esses currais eleitorais... eram currais inexpugnáveis... daqueles coronéis né?... que dominavam aqueles votos... e que com a MINHA candidatura esses currais acabaram sendo colocados abaixo... ah foi uma... uma eleição... em que da minha coligação fazia parte o PC do B PC do B estava na coligação comigo para governador do estado... e eu conheço bem e alguns de vocês conhecem... eu admiro... o trabalho do PC do B e tenho lá pessoas com as quais eu me relaciono... e eles não iriam entrar em nenhum projeto... que fosse um defender oligarquias ou muito menos é:: a manutenção de currais eleitorais... de modo que :: e/ no no que diz respeito à campanha presidencial... é claro... eu não era conhecido... tanto que eu tinha manifestei a minha intenção de:: sair candidato... eu tinha um porcento eu alcancei... ah:: emparelhei com o Brizola e com o Lula... ah::: em::..... maio ((pausa prolongada)) maio... junho... de 89... foi aí que nós emparelhamos numa pesquisa do GALUP... a partir daí... houve um crescimento grande da candidatura... houve um crescimento grande... eu tive/cheguei a quarenta e cinco porcento das intenções de voto... e depois... caí... de julho... até:: outubro... quando foi a eleição... eu caí para vinte e quatro ou vinte e cinco porcento das intenções de voto no primeiro turno... eu tive vinte e um milhões de votos... o Lula teve onze milhões e o Brizola teve dez milhões e quinhentos os dois disputaram até o último momento qual deles... estariam no/no segundo turno bom... agora então em relação a sua e a questão conjuntural... a democracia ah::: uns dizem não porque democracia porque a democracia tá é::: falha a democracia está doente a democracia é isto ou aquilo... nós temos que entender para facilitar o raciocínio... vivemos numa democracia ou não?... então a primeira pergunta é a seguinte há eleições livres? há... os poderes funcionam independe e livremente o congresso nacional justiça e o executivo? funcionam... a imprensa é livre?... a imprensa é livre?... é... então esses são os três fatores que convencionamos utilizar para saber... rapidamente... se vivemos numa democracia ou não é claro que a democracia significa isso... é o embate de/ de idéias é a troca de opiniões... quer dizer é::: ninguém é:: partidário somente de uma coisa... todos nós temos as nossas opiniões e o importante é que nós possamos expressar a nossa opinião... e só podemos expressar a nossa opinião num regime democrático como hoje estamos fazendo aqui... o que acontece no campo... é:: o que verificamos é... uma absoluta falta de controle... do governo... em relação a esta situação... porque quando começa é::: irmãos ou brasileiros a trocarem tiros... no:: no campo... e em busca da terra ou pela posse da terra... nós começamos a verificar o seguinte vem cá e onde está o governo nisso tudo... por quê que o governo não intervém de uma forma nesse conflito e diz pera aí mi/é gente vamos parar com isso... 605 venham pra cá vamos nos sentar... então senta o aqui o movimento dos sem terra senta o :: representante da bancada o... o dos ruralistas... sentase ministro da agricultura da reforma agrária ministro da justiça vem cá... o que que você quer... anota... o que que agente pode dar... anota... vamos chegar aqui então a um consenso isso a gente pode não pode e é assim que se faz... essa coisa de buscar na bala... e com vítimas... disputa pela terra isso é coisa da idade média... hoje em dia não se pode mais entender que numa numa num estágio da civilização em que nós esteja/ e 
que nós estamos... que nós assistamos pela televisão diariamente... essas cenas terríveis... de saque não é? de de :: pessoas atirando umas nas outras e sem que o governo tome uma iniciativa para resolver essa situação... então ah ah:: situação do Brasil é é diferente da Colômbia porque as raízes culturais nossas são diferentes das raízes... da... Colômbia e de outros países nós não temos uma tradição é::de:: ah::: é::: de de um país que se forma em guerrilhas... para combater isso ou aquilo ou aquilo outro porque hoje... o combate se faz pelos partidos políticos e pela eleição que se processa regularmente a cada dois anos dois anos pra::: de dois em dois anos nós temos eleições porque intercaladas prefeito e vereador e depois governador e senador e presidente da república... então numa sociedade em que... há de dois em dois anos a oportunidade da população se manifestar livre e abertamente pelo voto a sua satisfação ou a sua insatisfação... é o caminho que nós temos naturalmente para resolver os nossos conflitos desde que tenhamos um governo... com pulso... um governo com iniciativa e com sensibilidade... de verificar que não podemos deixar prosperar essa situação hoje no campo... sobre pena de entrarmos num clima... de muito perigo que não interessa a nenhum de nós

L1: agora é verdade que:::esse governo comparati/tô aqui ((se levanta)) comparativamente esse governo tem feito MUIto... em relação ao governo ::: que o senhor teve em relação à reforma agrária

L1: famílias foram assentadas isso isso é

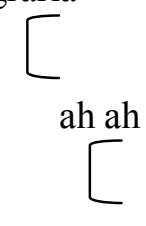

muito mais

L2:<smiles>CCCCCCCCCCCCCCCCCCCC</smiles>

L1: $\quad$ uma verdade né?

640 L2: é uma verdade agora veja um:: veja que paradoxo veja que paradoxo o o::: governo FHC... foi aquele que mais assentou... sem dúvidas... foi o que mais assentamentos fez... bom e se é o governo que mais assentamentos fez... por que... hoje estamos assistindo a essa enorme revolta dos sem terras? não há aí um paradoxo?... porque se é o governo 645 que mais assentamentos fez... então se deveria dar a ele um certo crédito... e deveria o movimento estar de alguma forma satisfeito porque está vendo a proposta da reforma agrária avançar... e porque nunca 0 clima... no:: na região na zona rural o clima no interior nunca esteve... TÃO tão grave nunca esteve TÃO aceso nunca as paixões ficaram desen/ desencadeados de uma maneira TÃO forte... por quê? porque o programa de reforma agrária não está sendo feito da forma que deveria ser feito... não adianta a gente a gente chegar numa fazenda retaliar e dizer você então fica com este pedaço de terra você fica com este e você com aquele... o que... o que tem que se fazer é ao mesmo tempo em que se dá a terra tem que se dá a semente... tem que se dar o apoio técnico para plantar... tem que se ter uma política de preços mínimos para garantir... a remuneração do:: de que ele vai produzir... tem que haver as vias de escoamento para poder retirar a safra de onde está para os locais de 
distribuição... tem que haver também uma mínima infra-estrutura... para que ele possa manter o assentado possa manter a sua família... tem que ter um posto de saúde tem que ter uma escola porque senão o que ele vai fazer naquele meio de mundo... com a mulher com os filhos e ele sem/se tiver uma doença não tem onde levar se o filho... o filho quer estudar e não pode... então o que falta é exatamente isso é uma consciência... global... do problema da reforma agrária... e esse governo embora tenha feito/ foi o que mais distribui foi o que mais assentou... foi e::e:: não está dando resultado por quê? porque não está dando a infra-estrutura mínima necessária... para que esses assentamentos possam funcionar a contento

L17: durante as eleições em $89 . .$. você falou que o Lula ia confi/ confiscar as poupanças e quem acabou fazendo isso um dia depois de ser eleito foi você... cê acha que um:: candidato POde mentir para ser eleito ou omitir?

L2: $\quad$ veja que eu ((gritos e aplausos)) o termo o termo confisco não é não é o termo que a gente possa... que a gente possa utilizar nesse caso... confisco é um termo... que a gente que a gente usa né?... para dizer éh::::de um ato de um gesto de se tomar alguma coisa e não se devolver... então na questão dos ativos no bloqueio dos ativos não houve confisco porque todos esse recursos foram devolvidos até o último centavo... né? ((gritos)) remunerando isso com juros e correção monetária acima da::da inflação (gritos)... bom... bom como eu já disse como eu já disse a vocês é preciso também que a gente veja o momento em que isso foi foi feito não é... quer dizer... naquele momento em que eu assumi... havia... havia uma inflação de noventa porcento ao mês... havia portanto uma inflação de três porcento ao dia... havia um excesso de moedas em circulação... e nós para iniciarmos o governo e implantarmos o nosso programa econômico... nós tínhamos que criar estabelecer um um espaço um momento para de tranqüilidade no que diz respeito à inflação para aplicarmos o nosso programa... a inflação para o mês de abril estava prevista para chegar a quase duzentos porcentos e aí isso seria uma loucura... bom... então o que... que nós e::: fizemos na::ah::ah:: no:: no 690 nosso projeto passava por um congelamento temporário de preços ou seja... para combater a inflação... nós temos que dar um congelamento temporário de preços... para exatamente os preços parassem de crescer e para que nós pudéssemos aplicar as medidas... no entanto... com aquela inflação alta e de repente os preços param de subir... o que que aconteceria com todos aqueles que tivessem com o seu dinheiro... a primeira idéia o primeiro gesto o primeiro impulso era de ir para o consumo... ou seja aquela geladeira que deixou de ser comprada o liquidificador que não foi comprado o sofá ou isso ou aquilo... ia tudo isso para o consumo porque de repente... a população ver/verificaria que 700 poxa os preços pararam de crescer... vamos consumir... e esse consumo seria um consumo violento... o que quebraria todo o sistema financeiro e também o sistema produtivo é ah: a questão do bloqueio foi uma medida de urgência e de emergência é:: de urgência urgentíssima e de emergência que foi tomada exatamente para evitar que isso não acontecesse ah:: naturalmente se vocês me perguntam é... faria isso de novo NÂO eu não faria isso de novo e contraria qualquer outra medida... ((gritos)) porque causou porque causou isso que vocês estão dizendo causou desassossego causou angustia e::: causou sem dúvida nenhuma um trauma na sociedade brasileira 
710 L1: é:: o tempo acabou:.: infelizmente... tem muitas perguntas... a serem feitas eu sei... o tempo acabou... olha o:::s troncos aqui... dos telefones congestionaram todos... teria algum telefone para que as pessoas pudessem... a gente... vai dar as perguntas... ao senhor e talvez o senhor possa responder... mas de qualquer maneira... eu queria agradece a vinda... ao Programa Livre e reiterar... se... outra vez for possível que voltasse porque:: muita gente... ficou com (vontade)

L2:

olha quantas vezes quantas vezes Sérgio havendo oportunidade é com muito prazer que eu voltarei aqui para continuar ah... esse debate

720 L1: bom... obrigado vocês por terem vindo... muito obrigado pelas... perguntas... até amanhã com mais um Programa Livre tchau 
ANEXO 2

DVD 